Priscila Loyde Gomes Figueiredo

\title{
Macunaíma: enumeração e metamorfose
}

Tese apresentada ao Departamento de Letras Clássicas e Vernáculas da FFLCH-USP como exigência parcial para a obtenção do grau de Doutor em Filosofia, sob a orientação do Prof. Dr. Valentim Aparecido Facioli. 
UNIVERSIDADE DE SÃO PAULO

2006 


\section{Resumo}

Este trabalho consiste num estudo sobre o romance Macunaíma, de Mário de Andrade. Ele procura investigar o estilo enumerativo da obra. A intenção é relacionar tal procedimento, que toma sobretudo objetos da natureza brasileira, ao atraso material e cultural e à tentativa de preencher tal lacuna. Busca-se ainda interpretar as constantes metamorfoses ontológicas como um desdobramento desse estilo e do sentido a que ele dá forma.

\footnotetext{
Abstract

This work is a study on Mário de Andrade's novel Macunaima. It focuses on numerative style wide used by the author, among others on the same period. The intent is relating such procedure, which involves above all objects from brazilian nature, to the material and cultural backwardness and to a trial on fulfilling such lack. It seeks also to analyze the frequent ontological metamorphoses as a development of that style and of the meaning that it conceives.
} 


\section{Índice}

$\begin{array}{lc}\text { Agradecimentos } & \text { p. } 4 \\ \text { Introdução } & \text { p. } 5 \\ \text { I-Suíte e variação } & \text { p. } 8 \\ \text { II- Oráculos emudecidos - pequeno excurso sobre um poema de Oswald } & \text { p. } 53 \\ \text { III - Enumeração e metamorfose } & \text { p. } 61 \\ \text { Bibliografia } & \text { p. } 95\end{array}$ 


\section{Agradecimentos}

A Valentim Facioli, meu orientador desde a iniciação científica e com quem minha formação intelectual tem uma grande dívida. Agradeço ainda a sua liberalidade e paciência.

Aos amigos e colegas que de algum modo contribuíram para o desenrolar dessa tese. Entre eles, Airton Paschoa, Anderson Gonçalves, Andrea Saad Hossne, Elaine Armênio, Fabio Weintraub, Milton Ohata, Marcus Mazzari, Sandra Moreira, Sérgio Alcides, Viviana Bosi e Tércio Loureiro Redondo.

Ao grupo interdisciplinar de estudos coordenado pelo professor Paulo Eduardo Arantes pelo estímulo intelectual imenso, que ainda não sei avaliar.

Agradeço ainda ao CNPQ pela bolsa de doutorado concedida durante 18 meses.

À Secretaria do Departamento de Letras Clássicas e Vernáculas e, em especial, ao setor de pós-graduação, na figura de Jacó, pelo sempre eficiente e cordial apoio. Do mesmo modo agradeço ao Luiz, do mesmo setor do Departamento de Teoria Literária e Literatura Comparada.

A Iumna Maria Simon e a José Miguel Wisnik, pelas observações, sugestões e críticas levantadas no exame geral de qualificação. Em relação à professora Iumna, os agradecimentos se referem a mais do que essas contribuições.

Ao Luiz e a meus pais, por todo o apoio possível. 


\section{INTRODUÇÃO}

De um modo genérico, Macunaíma nos faz rir da matéria com relação à qual Paulo Prado, em Retrato do Brasil, pretendeu nos fazer chorar. Como o ensaio, a sátira quis nos distanciar, sem nos subtrair ao prazer estético, porém, da lamentável realidade de que fazia alarde o pensamento social crítico da época, ao qual dava razão. Não obstante, é preciso levar em conta, com Alfredo Bosi, que ela "se disfarça e se atenua em meio a brincadeiras de linguagem e de construção. Se o lastro 'negativo' não fosse contrabalançado pela adesão lúdica e simpática à mente selvagem, o sentido último de Macunaíma se cifraria na mais cáustica das acusações já movidas às mitologias do caráter nacional brasileiro"; contudo as coisas não se passam exatamente assim, pois "a memória afetiva (...), investida de um pathos fortíssimo, foi trazendo para o interior da rapsódia um quase infinito viveiro de imagens e cenas, ritos e lendas, frases e casos que constituíam o seu mais caro tesouro, a fonte inexaurível do seu populário luso-afro-índio-caboclo..."1. Esse viveiro de imagens e cenas, ritos e lendas e, mais do que isso, o empenho em multiplicá-las - por centímetro quadrado mesmo, e não há hipérbole nisso - e dotálas de nitidez, de fazê-las rebrilhar de uma maneira inédita, tirando partido de suas potencialidades, como procurarei mostrar no início deste trabalho, fez o livro se saturar de concretos. Uma das perspectivas amplamente exploradas foi o "excesso de substantivos das línguas primitivas",2, mais próximas da percepção sensorial e

\footnotetext{
${ }^{1}$ Alfredo Bosi, "Situação de Macunaíma", in Macunaíma, pp. 176-177.

${ }^{2}$ Lévy-Bruhl, La mentalité primitive, Paris, Libraire Félix Alcan, 1922, p. 234.
} 
mais distantes do conceito, da intrincada síntese de mediações relativas a um objeto, ação ou fenômeno ${ }^{3}$ (o que não quer dizer que não haja nelas uma tendência para a abstração). A saturação de concretos no livro se dá como saturação de substantivos, de enumerações. Isoladamente consideradas, não são caóticas. Não seriam disjuntivas, e sim conjuntivas, para falar com Leo Spitzer no texto famoso sobre a enumeração caótica na poesia moderna. Ele ressalva como os elencos em Rabelais tinham propósito construtivo: explorar ao máximo a riqueza nativa da língua. O que Bastide e Bandeira reconheceram ser o caso aqui.

A ânsia inventariante do livro, um colorido catálogo, tem propósito sistemático, de esgotamento de possibilidades. Os concretos são exaustivamente compilados, como substantivos, e como estruturas, imagens e cenas. Nesse sentido podemos entender a enumeração no contexto dessa obra também como composição rapsódica. A metamorfose, um mitologema evidentemente presente numa narrativa com tantos feiticeiros, é mais uma força para a multiplicação de concretos, e, no cruzamento que Mário faz entre tantos documentos folclóricos prévios, essa força dobra. No livro, o automóvel é automóvel e onça, Maanape é homem e telefone, Naipi é índia e cascata, Capei é Lua e serpente-dragão, Oibê é minhocão, lobisomem, cachorro-do-mato, borboleta azul e homem" ${ }^{4}$, etc., e quase tudo "já foi gente um dia que nem nós"; e muitos seres podem virar constelação ou pedra. São fileiras de substantivos, e por vezes, raras é verdade, fileiras caóticas como Maanape. Porém, como ocorre com os substantivos misteriosos do livro, o que mais chama a atenção nas metamorfoses é a sua quantidade. Nós as sentimos como uma corrente elétrica através da qual tudo desata a funcionar. Elas são o verdadeiro

\footnotetext{
${ }^{3}$ A esse respeito, cf. Lukács, Ästhetik I, p. 57 em diante.

${ }^{4}$ Macunaíma, p. 145.
} 
maquinismo aqui - uma força produtiva que multiplica imagens. Qual o sentido de tanta saturação? Macunaíma é uma extensa enumeração nominal, mas fundamentalmente de bichos, plantas, entes fabulosos, acidentes geográficos ("muitos funcionários públicos!" também). O ponto de vista primitivista faz que máquinas sejam processadas em termos de produtos primários, retirando-lhes todo o valor agregado. Tal é uma das primeiras impressões que Macunaíma tem de São Paulo, segundo a qual os edifícios se reduzem a malocas, os elevadores a sagüis, o ruído urbano a ruído orgânico, as chaminés a boitatás e assim por diante. Quando deixa a cidade, Macunaíma faz um caborje e a transforma num bicho-preguiça de pedra, o que talvez seja a síntese de um processo regressivo: cultura $\rightarrow$ natureza orgânica $\rightarrow$ natureza inorgânica. Segundo Marx, não se "produzem as abstrações mais gerais [mais complexas] senão onde existe o desenvolvimento concreto mais rico (...)" ${ }^{, 5}$. Macunaíma é colorido como um mosaico, vivaz, prenhe de coisas; mas elas valem muito pouco, como os pescados e caças dos personagens, como o papiri que Macunaíma e os manos começam a construir para morar. Sua quantidade imensa, porém, quantidade que aumenta com a decomposição de produtos complexos em objetos mais simples, deve significar que ela ainda não foi suficiente para atingir um nível mais complexo de abstração. As metamorfoses constantes e cumulações de concretos são como as lavouras de subsistência amplamente cultivadas para garantir a acumulação no novo sistema produtivo instaurado com a Revolução de 30.

\footnotetext{
5 "Para a crítica da economia política", in Manuscritos econômico-filosóficos e outros textos escolhidos (Trad. de José Carlos Brunni, José Arthur Giannotti e Edgard Malagodi). São Paulo, Nova Cultural, 1987, p. 19.
} 


\section{Macunaíma - enumeração e metamorfose}

O leitor consinta em acompanhar a narrativa reproduzida logo abaixo, “Akalapijéima e o Sol”, de Mitos e lendas dos índios taulipangue e arekuná, contos ameríndios recolhidos por Koch-Grünberg, publicados em 1916 e que, como se sabe, sugeriu a ação básica de Macunaíma:

Antigamente, existia uma árvore muito alta. Walo'ma, o sapo, subiu no topo dela, mas um homem chamado Akalapijéima ficava espreitando toda tarde ao pé da árvore, para pegar Walo'ma. Walo'ma disse: "Se Akalapijéima me pegar, eu o jogarei no mar!" O homem agarrou-o, finalmente. Então Walo'ma o pegou pelas mãos e o empurrou com o pé para dentro do mar. Carregou-o nas costas, mergulhou e nadou com ele para uma ilha. Lá o deixou e voltou nadando. Deixou-o debaixo duma árvore, na qual havia urubus que defecaram em cima dele enquanto ele dormia. (O sapo havia advertido Akalapijéima de que não o pegasse, porque então o jogaria no mar.)

Fazia muito frio na ilha e o homem tremeu bastante. Aí apareceu Kaiuanóg, a estrela da alvorada, quando ele já estava todo coberto com detritos dos urubus e fedia bastante. Ele pediu à estrela que o levasse para o céu. Ela respondeu: "Não te posso levar para cima comigo, pois nada me deste. Só deste bolos de mandioca ao Sol." (Porque o Sol brilha de dia e a estrela de noite.) O homem 
então pediu à estrela que lhe desse fogo, porque estava com muito frio. Kaiuanóg disse: "Não te quero ajudar! O Sol que te ajude. Ele ganha mais bolos de mandioca”. Kaiuanóg foi embora.

Então chegou Kapéi, a Lua. Akalapijéima pediu a Kapéi que o levasse de volta para sua terra. A Lua não queria levá-lo, porque ele havia dado muitos bolos de mandioca ao Sol e nada a ela! Então o homem pediu fogo à Lua, mas ela também lhe negou isso. O homem sentia muito frio e os urubus continuavam defecando em cima dele, pois a ilha era muito pequena.

Então chegou Wéi, o Sol. (Foi a sorte dele, pois havia dado ao Sol muitos bolos de mandioca.) O Sol o levou consigo na sua canoa. Mandou que suas filhas o lavassem e cortassem o seu cabelo. Ele ficou de novo bonito. Wéi queria tê-lo para genro. Akalapijéima não sabia que ele era o Sol e pediu a Wéi que chamasse o Sol para aquecê-lo, pois sentia frio, agora que fora lavado e sentara na proa da canoa. (Porque era muito cedo e o Sol ainda não tinha força. Por isso Akalapijéima sentia muito frio.) Então Wéi colocou um enfeite de penas de papagaio na cabeça. Akalapijéima estava sentado com as costas voltadas para a canoa. Wéi lhe disse: "Vira-te!" Quando ele se virou, Wéi colocou por cima do enfeite de penas uma chapéu de prata e, nas orelhas, brincos de asas de besouro. Então o dia ficou quente (porque já era tarde). Wéi aqueceu o homem, ficou muito quente e ele sofreu com o calor; a canoa foi subindo cada vez mais alto no céu. Quando Akalapijéima sofreu por causa do calor, Wéi lhe deu roupas. Então o homem não sentiu mais calor.

Wéi queria-o para genro. Disse-lhe: "Deves casar com uma de minhas filhas, mas não cortejes outra mulher!" Wéi parou numa maloca, desceu com as filhas e entrou na casa. Ordenou a Akalapijéima que não deixasse a canoa nem se apaixonasse por outra mulher. Wéi entrou na casa. Akalapijéima assim mesmo desembarcou e encontrou algumas moças, as filhas do urubu. O homem achou-as muito bonitas e se apaixonou por elas. Wéi e as filhas de nada sabiam, pois tinham entrado na casa. Quando voltaram para junto da canoa, encontraram Akalapijéima gracejando no meio das filhas do urubu. 
As filhas do Sol ralharam com ele e disseram: "O nosso pai não lhe disse que ficasse na canoa e que não descesse à terra? Não foi o nosso pai quem retirou você da ilha? Sem a ajuda dele, você agora não estaria neste bom estado. Além disso, já está apaixonado pelas filhas do urubu!" Então Wéi zangou-se também com ele e disse: "Se tivesses seguido o meu conselho e casado com uma de minhas filhas, terias ficado sempre jovem e bonito como eu. Agora só ficarás jovem e bonito por pouco tempo. Depois ficarás velho e feio!” Então foram dormir, cada qual no seu canto. Num lado, Wéi e suas filhas, no outro Akalapijéima.

No dia seguinte de manhã bem cedo, Wéi foi embora com suas filhas e abandonou Akalapijéima ainda dormindo. Quando ele acordou, achou-se no meio dos urubus, velho e feio, conforme Wéi lhe havia dito. As filhas do Sol se espalharam e iluminam agora o caminho dos mortos. Akalapijéima casou-se com uma das filhas do urubu e acostumou-se àquela vida. Foi nosso ancestral, o pai de todos os índios.

Por isso ainda hoje vivemos assim. Ficamos jovens e bonitos por pouco tempo, depois nos tornamos feios e velhos. ${ }^{6}$

Na rapsódia, o capítulo "Vei, a Sol" é inserido entre o episódio da macumba carioca, em que Macunaíma, ali identificado como filho de Exu, tem a oportunidade de atacar o gigante por via de seu maligno pai encarnado no corpo de uma polaca, e a "Carta às Icamiabas", na qual o herói pede dinheiro para continuar sua difícil empresa na terra bandeirante - na verdade pede algumas toneladas de bagos de cacau, pois, como seu irmão mais velho percebera desde a chegada a São Paulo, estes podiam ser aplicados na Bolsa. Sabemos que "Maanape era feiticeiro"; portanto é de esperar que estivesse capacitado a decifrar a operação cacau -

\footnotetext{
${ }^{6}$ Makunaíma e Jurupari - cosmogonias ameríndias, Sérgio Medeiros (org.), São Paulo, Perspectiva, 2002, pp. 76-78.
} 
commodity, pela qual algo muito palpável se metamorfoseava em título ${ }^{7}$. Bem, voltando, o fato é que, saindo na madrugada após a "horrorosa" sessão de afroespiritismo, pela qual Piaimã telepagara quase todos os pecados, Macunaíma ainda continuava no Rio de Janeiro. Isso possibilita a Mário aproveitar a ilhota da

\footnotetext{
${ }^{7}$ Macunaíma explica por que o dinheiro tinha se acabado: "O tesouro que daí trouxemos [e foram 200 canoas de cacau, o que deu à chegada ao Tietê um verdadeiro ar de vinda de família real ou de expedição colonizadora - "Na frente Macunaíma vinha de pé, carrancudo", pp. 36-37] foi-nos de mister convertê-lo na moeda corrente do país [um pouco do carregamento eles guardaram para comer e o resto barganharam na Bolsa, obtendo 80 contos de réis, pois "Maanape era feiticeiro", ver p. 39]; e tal conversão muito nos há dificultado o mantenimento, devido ás oscilações do Cámbio e á baixa do cacau" (p. 74). E seguem-se pelo menos cinco páginas só para falar de como são caras as mulheres de São Paulo, que não se "derribam” pela força, como as suas índias conhecidas, mas só "a troco de oiro e de locustas" (p. 77). Por fim, depois de dar notícias de outros aspectos da vida paulista, enfatiza que as negociações com Venceslau estão bem encaminhadas e pede às moças que não esqueçam as "alvíçaras que enunciàmos atrás", pois "com pouco o vosso abstémio Imperador se contenta; si não puderdes enviar duzentas igaras cheias de bagos de cacau, mandai cem, ou mesmo cinqüenta!” (p. 85). E disso, supomos, o imperador mais os irmãos vão poder viver em São Paulo, até que o primeiro ponha a perder os últimos 40 contos no episódio em que um mascate sírio lhe vende um gambá encantado, cuja virtude seria defecar moedas de prata. Na verdade, o tequeteque tinha aceitado, depois de propor 400 contos, fazer o preço de 30. Mas o seu cliente só possuía um título com o valor de 40, dá este mesmo e fica envergonhado de pedir o troco (p. 113-114) - e de parecer pobre, decerto. Depois desse acontecimento, os irmãos "vararam o Brasil todo (...) pra ver si não achavam alguma panela com dinheiro enterrado" (p. 115), hábito que Macunaíma tem desde bebê. Como último expediente, pedem os palpites de Maanape, que "era feiticeiro", estamos sabendo, para jogarem no bicho. E assim vão se arranjando até que voltem pra sua terra (p. 118), onde não se arranjarão mais. As páginas referidas pertencem à edição crítica de Macunaíma, coordenada por Telê Porto Ancona Lopez e incluída na "Coleção Arquivos" (Paris/Brasília, Association Archives de la Littérature latino-americaine, des Caraïbes et africaine du XX $\mathrm{X}^{\mathrm{e}}$ siècle/CNPq, 1988, $1^{\text {o }}$ ed.). De agora em diante, todas as citações tiradas desta edição (e eventualmente dos ensaios, correspondências, documentos fac-similados que a acompanham) serão assinaladas por meio simplesmente de
} Macunaíma. 
narrativa ameríndia como um montículo de terra "além da Baía de Guanabara", com o que também é preservado o engraçadíssimo motivo, de visualidade de quadrinho, dos urubus defecando em cima da cabeça de Akalapijéima porque, se o fizessem um pouco fora desse diâmetro, já estariam sobre o mar; pela mesma razão é que o rapaz não poderia se esgueirar para fora. Com isso se sugere que a jurisdição da cabeça é praticamente a da ilha, e a situação, portanto, é da ordem da inexorabilidade, cômica como pimenta no olho do outro. Talvez ainda isso fosse um modo de tirar da cápsula do provérbio "Quando urubu está de caipora o de baixo caga no de cima", uma possível história enovelada (semelhante à história de Akalapijéima justamente... situada em outro ponto do mapa folclórico), ainda que com os personagens em situação invertida. Esse provérbio sai da boca de Macunaíma em meio às desgraças acumuladas do último capítulo. Em comparação a este, o episódio com Vei torna-se retrospectivamente atenuado do ponto de vista dos padecimentos do personagem, e o dito passa agora a ser a medida exata, mas metafórica, de seu azar, sugerindo que, mesmo que Macunaíma fosse o urubu sobre a cabeça de alguém, seria bem provável, de tal modo sua sorte mudou, a cabeça fazer necessidade em cima dele. A situação aqui consegue ser muito mais calamitosa que a enfrentada na baía de Guanabara. Antes, no capítulo VIII, o conteúdo da frase curiosamente aparecia como que desdobrado em sua literalidade pictural, procedimento muito comum no livro, através do qual o movimento para a generalização na linguagem da sabedoria popular é desativado, e esta é obrigada a olhar para trás, para as imagens sensórias de que se afastava. A maneira das narrativas etiológicas é mimetizada a ponto de

\footnotetext{
${ }^{8}$ Macunaíma, p. 164. Segundo Cavalcanti Proença, esse dito apresenta muitas variantes, algumas registradas por Afrânio Peixoto e Leonardo Mota. Cf. Roteiro de Macunaíma, Rio de Janeiro, Civilização Brasileira, 1977, p. 121.
} 
virar um mecanismo: tanto elas podem ser criadas pelo escritor conforme as frases lapidares anônimas disponíveis, caso mais freqüente, ou conforme as de autoria conhecida (pois inevitavelmente o histórico e até o publicitário adquirem a aparência de folclórico no meio ambiente da obra), como podem ser retiradas inteiras de uma cosmogonia primitiva e se tonificar na colagem de fragmentos de procedência variada ${ }^{9}$. Essa revitalização pode ocorrer inclusive pelo acréscimo da anotação mais empírica. Contudo ainda nesse caso a aparência fabular é mantida, com sistemáticos drenos embora, que têm antes o efeito de sabotar o conjunto da vida que parece não espelhada aqui. Mas estamos nos adiantando. No caso de Vei, ocorrem aquelas duas operações. O relato arekuná traz por si só o incidente referido, contudo Mário o modificou um pouco: "Caiu dormindo embaixo duma palmeirinha guairô, muito aromada onde um urubu estava encarapitado. //Ora o pássaro careceu de fazer necessidade, fez e o herói ficou escorrendo sujeira de urubu" ${ }^{\prime 1}$. No registro do mito, está "os urubus"; em Macunaíma, "um urubu"; no adágio popular, "urubu”. Este, devido ao singular e, num contexto tão breve, devido ao fato de ser o único substantivo concreto - pois "o de baixo", conquanto seja o sujeito da segunda oração do dístico, é um qualificador apenas da posição e, assim, por demais impreciso -, está mais apto para a personificação que o vago plural usado no mito, o qual não dá muito mais destaque ao pormenor. Mário de Andrade, provido de um microscópio, lhe dá toda a atenção possível e retarda um passo que seria de ordinário mais rápido.

\footnotetext{
9 "Esse processo, parasitário na aparência, é no entanto curiosamente inventivo; pois, em vez de recortar com neutralidade nos entrechos originais as partes de que necessita para reagrupá-las, intactas, numa ordem nova, atua quase sempre sobre cada fragmento, alterando-o em profundidade" (Gilda de Mello e Souza, O tupi e o alaúde, São Paulo, Duas Cidades/Editora 34, 2003, p. 10, grifo meu).

${ }^{10}$ Macunaíma, p. 65.
} 
Mostra-se como o urubu, singular e definido, está bem folgado, simpaticamente encarapitado até que "careceu de fazer necessidade, fez", com muita pachorra e domínio da situação. Ele pode não falar como outros animais no livro, pois é mais figurante que coadjuvante; ainda assim, é relativamente dotado de espírito, como num desenho animado que não dá voz a certos bichos, por exemplo o cachorro do respeitado Mickey. Este é um rato que age e fala à maneira dos humanos; mas seu cachorro, embora não tornado ereto como o dono, também possui feições humanizadas. Apenas é tão pacato a ponto de fazer crer que sua privação de linguagem é na verdade uma avisada indiferença. Ante esta, toda articulação verbal parece um exagero neurótico. Do mesmo modo, posto debaixo do tranqüilo urubu, Macunaíma fica na difícil posição em que, se disser um isto, faz a gente rir mais.

A árvore sob a qual dorme, que o reconto não especificava e o provérbio tampouco mencionava, se torna aqui uma palmeirinha guairô, muito aromada. Os leitores em geral não poderão conceber com exatidão a imagem a que se refere o significante desse tipo de palmeira; mas esta, um elemento notoriamente tropical, já é uma delimitação em relação a árvore. E, embora não possamos desenhar em nossa mente o que seja guairô, mesmo que este conste no glossário de Cavalcanti Proença, que evidentemente não o traz pintado ${ }^{11}$, tomamos a imagem da planta agora como singularizada, em parte pela filiação a um gênero conhecido, em parte pela força evocativa do adjetivo exótico e oxítono, que imediatamente libera ressonâncias nativas $^{12}$. A flexão no diminutivo, por sua vez, envolve com um ar de família o

\footnotetext{
${ }^{11}$ Roteiro de Macunaíma, p. 268.

12 Mais exatamente, ressonâncias tupis. "As vogais são como o sopro imediato do espírito, a forma formante (o afirmativo); as consoantes são o corpo da linguagem ou a forma formada (o afirmado). // Portanto, quanto mais vogais há numa língua - mas de modo que a limitação mediante consoantes não desapareça até um certo grau -, tanto mais animada, e inversamente, quanto mais sobrecarregada
} 
termo determinado e o termo determinante, o que tranqüiliza um pouco o exotismo deste e sugere que a intenção não é fazer ciência classificatória. $\mathrm{O}$ predicativo colocado logo após, "muito aromada" - que, penso eu, deve ser lido em tom de devaneio, com o alongamento das tônicas, e como uma ilha perdida entre duas pausas, apesar da fixação escrita lhe dar uma única vírgula -, confirma a intenção de apaziguar a aura de palavras esquisitas, que ficariam por assim dizer mais em casa. Uma tal tendência supostamente manifestaria antes a elocução à-vontade de um matuto experimentado na paisagem natal, que, durante sua narração, se especializa por vezes animais, plantas, acidentes geográficos, o faz por acaso: um pitiguari (...) se desgoelou cantando, debaixo de uma palmeirinha guairô, as formigas jaquitaguas ruivinhas etc... ${ }^{13}$. Mas sabemos que não é bem assim muito antes de ler a advertência do narrador no "Epílogo" segundo a qual ele cantara os casos da tribo Tapanhumas em "fala impura", não exatamente identificada ao original deitado pelo papagaio - a "fala mansa, muito nova, muito! que era canto e que era cachiri com mel-de-pau, que era boa e possuía a traição das frutas desconhecidas do

de consoantes, tanto mais desprovida de alma." (Schelling, Filosofia da arte, trad. Márcio Suzuki, São Paulo, Edusp, §73, 485, p. 141). Por razões parecidas Proust e Swann puderam admirar o modo de falar do tímido e bondoso Saniette: "Ao falar, saíam-lhe as palavras num balbucio verdadeiramente delicioso, pois via-se que isso denotava menos um defeito da língua que uma qualidade da alma, como que um resto de inocência da primeira infância. Todas as consoantes que não podia pronunciar correspondiam a outras tantas durezas de que era incapaz na vida" (Em busca do tempo perdido - No caminho de Swann, trad. Mário Quintana, São Paulo, Globo, p. 201). A língua tupi seria, desse ponto de vista, mais espírito imediato que enrijecimento e forma (dominação da natureza); e dele Macunaíma retira, como a uma seiva, animação, balbucio e onamatopéia.

${ }^{13}$ Macunaíma, pp. 65-66.

${ }^{14}$ Macunaíma, p. 168. 
mato" ${ }^{15}$. A esta estaria vedado o nosso acesso, pois a porta se fechara para sempre após a migração do pássaro para Lisboa. Antes disso, por sorte, um forasteiro tinha escutado o evangelho, e a memória dos feitos de Macunaíma pôde ser conservada ${ }^{16}$.

\footnotetext{
${ }^{15}$ Macunaíma, p. 168.
}

${ }^{16}$ Esse sistema de mediações entre a "fala nova" e a "fala impura" não é aqui mais complicado do que o que firma a relação entre o mito ameríndio e seu registro por Koch-Grünberg, que se serviu de informantes, prática comum, bem como a relação entre o apurado pelo etnógrafo e o elaborado pelo escritor: "Tudo leva a crer que Koch-Grünberg relacionava-se muito bem com os índios, mesmo quando não falava a língua nativa deles. Durante a expedição de 1911, por exemplo, pôde trabalhar com dois índios que eram grandes conhecedores das tradições orais de seu povo, Akúli, índio arekuná, e Mayuluaípu, índio taulipangue. Esses dois narradores não apenas consentiram em passar ao etnógrafo os contos que compõem a presente coleção, como também colaboraram um com o outro, uma vez que Mayuluaípu exerceu a função de intérprete de Akúli (índio que não falava português, língua usada nas conversas com Koch-Grünberg). Na verdade, Mayuluaípu foi mais do que um tradutor e esclareceu passagens obscuras dos relatos de Akúli, ou relacionou certas passagens dos mesmos à vida e à cultura das tribos karib (...). // Assim, o demiurgo Makunaíma, na grafia utilizada por Koch-Grünberg (...), foi apresentado ao etnógrafo alemão em diferentes versões dadas pelos dois índios, compondo um retrato multifacetado do famoso personagem (...)", Sérgio Medeiros, “A mitologia do viajante solitário”, in Makunaíma e Jurupari - cosmogonias ameríndias, cit., p. 16. Cabe lembrar que cada uma das lendas registradas é precedida do nome de seu narrador e que "Makunaíma não é o único trickster das histórias contadas por Akúli e Mayuluaípu: traços de trickster aparecem também nos protagonistas de outros ciclos de histórias, como Kone’wó e Kaláwunség, e em personagens de histórias isoladas [a onça, o jabuti e alguns heróis sem nome, como o que mata Piaimã], todos utilizados por Mário de Andrade na composição do seu Macunaíma" (Lúcia Sá, "Tricksters e mentirosos que abalaram a literatura nacional: as narrativas de Akúli e Mayuluaípu", in op. cit., p. 254). Segundo vaga indicação do próprio Autor e depois conforme a recensão de Cavalcanti Proença, personagens de outras porandubas folclóricas ainda forneceram inspiração a Macunaíma (para ficar só neste): "Basta verificar rapidamente algumas cenas para que isso fique bem acentuado. No capítulo I, é ele o Jabuti que caça o Tapir na armadilha; a seguir é Kalawunseg, o mentiroso, quando, pouco depois, inventa que viu timbó na beira do rio. E assim continua pelo livro adentro, sendo Pe. Anchieta quando viaja à sombra das asas dos papagaios e araras, Wewe dos taulipangues, o jabuti na festa do céu. Depois da macumba, Macunaíma é o próprio 
No entanto, como dizíamos, mesmo sem essa explicação, percebemos desde logo que não se trata da reprodução ou da estilização da fala de um homem integrado à cultura que narra - até porque as culturas estão desentroncadas aqui, combinando-se como numa síntese onírica, e a língua que lhe corresponde está na "extrema esquerda da língua” em matéria de tensão e dificuldade ${ }^{17}$, um tanto longe, portanto, da expressão pré-literária, bem menos esforçada, de um contador de causos.

Retomando a comparação de início, repare-se que, na lenda original, Volomã, que viria a arremessar o herói na ilhota, era um sapo. Mário de Andrade sumiu com o sapo e transferiu o nome para o tronco onde ele morava, dando-lhe além disso atributos que o tornam semelhante a Dzalaúra-Iegue, posta atrás da mansão de Venceslau Pietro Pietra ${ }^{18}$. Mas o conto arekuná dá ensejo, com a primeira frase, a esse deslocamento: "Antigamente, existia uma árvore muito alta". A construção faz acreditar que a árvore, se não fosse para ser protagonista, ao menos

Mário que sai em companhia de Manuel Bandeira, Ascenso Ferreira e outros; e logo se torna Akalapijeima, na ilhota da Guanabara. É o Carão que vai roubar o talismã de Jurupari; volta a ser Kalawunseg, mentindo que caçou viados em vez de ratos, é o jaguar logrado pelo chuvisco, é um tolo enganado por Kunewo, é o filho de Kaynkewe, quando se vê coberto de carrapatos; é outros heróis e outros vilões, variabilíssimo no correr do livro" (Roteiro de Macunaíma, p. 9). O campo continua aberto.... Sublinhe-se que já Koch-Grünberg relacionara ações, motivos e personagens das lendas colhidas com as de outras antologias do folclore indígena brasileiro, como as de Capistrano de Abreu e Couto de Magalhães, depois lidas e aproveitadas por Mário de Andrade. É o que faz, p. ex., com a figura do astucioso jabuti, comum a umas e outras. Ver, do autor alemão, "Parentescos e analogias", in Makunaíma e Jurupari, sobretudo pp. 222-224.

${ }^{17}$ Conforme se exprimiu, com bastante irritação, Rubem Braga. Apud Silviano Santiago, "A trajetória de um livro", in Macunaíma, p. 179.

18 "Por detrás do tejupar do regatão vivia a árvore Dzalaúra-Iegue que dá todas as frutas, cajus, cajás cajamangas mangas abacaxis abacates jaboticabas graviolas sapotis pupunhas pitangas guajiru cheirando sovaco de preta, todas essas frutas e é mui alta" ( Macunaíma, p. 42). 
teria um papel bem mais importante que o revelado logo no período seguinte, ou seja, o de mero elemento de cenário, rapidamente dispensado. O escritor toma a sério o que a ingênua exposição anuncia como relevante. Em sua elaboração, porém, a qual preserva o traço imediatista da frase, o erro de coesão lógica desaparece: "Macunaíma ia seguindo e topou com a árvore Volomã bem alta" 19 . Mas a lição desse tipo de erro formal, certamente mais absorvida com a teoria psicanalítica e a vanguarda artística e aprendida em muitas outras fontes, entre as quais a linguagem infantil, mostra-se em toda parte no livro. No trecho em questão, foi capturado antes o conteúdo que a deficiência de encadeamento deixou em aberto e não fora sintaticamente metabolizado. E assim a árvore sai homenageada. No lugar do sapo, por sua vez, aparece trepado num galho um pitiguari, que, com muita ansiedade (e graça para nós), "se desgoelou cantando - 'Olha no caminho quem vem! 'Olha no caminho quem vem!'”. Este, sim, seria um elemento acessório, pois é abandonado tão logo Macunaíma, que o olha com a intenção de agradecer - um dos tantos automatismos que o autor lhe cola humoristicamente, pois o personagem em geral agradece sem porquê $\hat{e}^{20}$-, vê que a árvore estava carregada de fruta, e a barriga dele, a que a fome, como uma potência, ressuscitava, "empacou espiando aquelas sapotas sapotilhas sapotis bacuris abricôs mucujás miritis guabijus melancias ariticuns, todas

\footnotetext{
${ }^{19}$ Idem, p. 65.

20 Talvez seja alusão ao modo de comportamento de pessoas que, não tendo sido iniciadas na educação burguesa, tomam destas certas normas difusas e, por insegurança na conduta social, as aplicam a torto e a direita. A tímida Macabea, de A hora da estrela, também vive agradecendo. No caso, o efeito é de um humorismo compungido. Em relação a Macunaíma, que não é uma pessoa, mas um híbrido lingüístico, o desacordo entre o agradecimento e seu objeto chega ao nonsense, pois o ato de gentileza é mais papel colado que reação. Ainda assim, o humorismo aqui também pende mais para o afetuoso do que para o corrosivo, justamente pela porção de realidade a que esse automatismo alude.
} 
essas frutas". O pau inicialmente caprichoso acaba por cedê-las vencido por palavras mágicas, sortilégio de que se vinga atirando o feiticeiro na pedra circundada por mar. O antagonista desse passo é outro que o da matriz, e a fantasia também se modifica: a vingança de uma árvore altíssima, da qual pendem frutas de formato e cor vários, e o movimento descrito são naturalmente mais pujantes do que o seriam se se originassem de um sapo. Na verdade, nossa imaginação teria uma dupla tarefa nesse caso: aumentar o tamanho do anfíbio e dotá-lo de uma movimentação vigorosamente antropomórfica (à qual a árvore, ereta e de raízes fincadas como pés no chão, se candidata com mais chance, ainda que não seja de natureza semovente). A imagem que resulta dessa operação é imprecisa. No romance, ela adquiriu bastante nitidez. E é esse o ponto. Conforme esclarece Cavalcanti Proença, a fórmula encantatória com que o herói rende Volomã, Boiôiô, boiôiô! quizama quizu!, fora tirada à lenda "O cágado e a fruta", colhida por Sílvio Romero, e na verdade consistia no próprio nome da árvore ${ }^{21}$. Essa informação mostra como é maior do que supomos a perspicácia aqui no aproveitamento de materiais prévios. Cavalcanti Proença nos permite concluir que o misterioso enunciado é então... a própria coisa que se queria submeter. Macunaíma reproduz lingüisticamente a essência da coisa para dominá-la, de fato um procedimento comum em práticas xamânicas - a "magia imitativa" de que fala Frazer. Veja-se então como num comecinho de capítulo já ocorre a síntese de ao menos dois documentos. Ela supôs a transferência para uma árvore, eleita para antagonista, do nome de um sapo em cima dela, que na nova versão virou um ornamental e desgoelado passarinho, e o aproveitamento do nome de uma outra árvore em instrumento para hipnotizá-la. São deslocamentos metonímicos e que se prevaleceram também de uma semelhança,

${ }^{21}$ Roteiro de Macunaíma, p. 170. 
digamos, cênica: o cágado diante da irredutível Boioiô e ávido por sua inominada fruta; o rapaz diante de uma inominada árvore e ávido de pegar o irredutível Volomã. Na astúcia de Macunaíma, por sua vez extraído do mesmo ciclo de histórias em que aparece Akalapijéima, a esperteza deste e a do réptil, distantes no mapa folclórico, puderam se dar as mãos e fortificar, adensando a breve linha de ação e primitiva reação ("Volomã ficou com ódio") que vai dar na Baía de Guanabara $^{22}$. Esta, por sua vez, é a ilhota onde Akalapijéima tinha sido arremessado etc., como vimos atrás, pois foi de fato o registro de Koch-Grünberg que forneceu o arcabouço para todo esse capítulo. Mas ele é um tanto apagado.

No conto do informante indígena, há pouquíssima descrição de estados emocionais. Um "e se apaixonou por elas" e "então Wéi zangou-se" são as indicações mais diretas de sentimentos; quando as filhas do Sol voltam para a canoa e surpreendem o moço de quem tinham cuidado nos braços das filhas do urubu, é dito que "ralharam com ele", ralho que vem em discurso direto, mas sem nenhuma adjetivação da parte dos interlocutores a sua atitude; Akalapijéima, por sua vez, cala-se o tempo todo e até o fim, seja ante a censura das moças a quem traiu, seja com a zanga do pai. E mesmo antes apenas sabemos de suas iniciativas de maneira mediada, através do lacônico narrador. Embora não seja premeditado, calha de o procedimento não ser esse com todos os demais, o sapo, Caiuanogue, Capei etc., cujas falas permitem que se entreveja algum estado psicológico (no caso da Lua, ocorre discurso indireto livre). É verdade que este é às vezes muito impreciso, como

\footnotetext{
${ }^{22}$ Como notou Alfredo Bosi, "Mário de Andrade procurou manter-se, em geral, fiel ao modo de construção dos heróis da mitologia amazônica, acionados direta e prementemente pelos estímulos do prazer ou do medo" (“Situação de Macunaíma", in Macunaíma, p. 179). E, acrescentaria, do ódio ou vingança.
} 
na respostas da estrela da tarde aos pedidos que Akalapijéima, tremendo de frio e fedendo a sujeira de urubu, lhe fizera um após o outro: “Não te posso levar para cima comigo, pois nada me deste. Só deste bolos de mandioca ao Sol'. (Porque o Sol brilha de dia e a estrela de noite)". O uso do verbo poder - está assim mesmo no alemão ("Ich kann dich nicht mit hinauf nehmen"23) - induz a pensar que há uma impossibilidade objetiva para a realização do pedido, e não se trataria de vingança. "Uma vez que nada me deste, não posso te levar para cima; infelizmente não está a meu alcance agir contrariamente à lei que me obriga a isso" é como lemos a primeira resposta, à qual o narrador acrescenta uma evidência fenomênica: o Sol brilha de dia, ao contrário da estrela; é natural, portanto, que sejam dados bolos de mandioca a ele, pois seu brilho é quente e pode secá-los. A explicação, no entanto, introduzida pelo porque, está algo solta em relação ao período anterior, o que produz ambivalência, pois não fica claro se o narrador justifica, com essa observação, a ação passada de Akalapijéima ou a atitude de Caiuanogue. Há uma diferença sutil entre uma hipótese e outra. Se a primeira estiver correta, então a réplica da estrela mostra que ela está de acordo com o que fizera seu interlocutor - ele respeitou a ordem das coisas, e agora é a vez de ela o fazer. No caso de ser a segunda, o sentido é o que expusemos há pouco: Akalapijéima não deveria ter dados bolos de mandioca apenas ao Sol; mas foi isso que ele fez, e está feito. Não obstante a estrela não ficou agastada: se pudesse, o levaria para o céu; não tendo recebido bolos de mandioca, contudo, não está autorizada a isso. Mas, no frigir dos ovos que é a resposta à solicitação de fogo, o sentido de desforra ganha evidência e invalida as hipóteses feitas: "Não te quero ajudar! O Sol que te ajude. Ele ganha mais bolos de mandioca". Mário não aproveitou esse motivo nas duas recusas ao herói, e sim

${ }^{23}$ Cf. Macunaíma, p. 51. 
apenas na disposição de Vei, a Sol agora, em ajudá-lo. O motivo para Capei e Caiuanogue não ajudarem o herói foi retirado antes do conto, transcrito por Couto de Magalhães, em que uma moça diz a um gambá que quer dormir com ela: "Não quero dormir com você, porque você é muito catinguento!"24

Para o nosso propósito é importante a observação de Gilda de Mello e Souza conforme a qual Mário de Andrade não deixa intacta a parte extraída dos entrechos originais, mas a elabora e carrega de ressonâncias ${ }^{25}$. Algo semelhante o Autor propunha para os compositores eruditos: apoiar-se em elementos de estabilização "étnica" no material folclórico e harmonizá-los - "Carecemos de um harmonizador simples, mas crítico" ${ }^{\text {26 }}$. Em termos filosóficos, a recomendação ficaria assim: nãoidentidade (o crítico) na identidade (o simples). Nisso teria consistido o progresso, durante o Romantismo musical, da antiga técnica da variação, outrora um procedimento exterior, "simples máscara de uma matéria que se conserva idêntica"27, agora um elemento integrante da composição, posta a serviço do

${ }^{24}$ O selvagem (São Paulo, Companhia Editora Nacional, 1935, pp. 254-255). A descoberta dessa referência é de Cavalcanti Proença.

${ }^{25}$ Ver nota 4.

${ }^{26}$ Ensaio sobre a música brasileira, São Paulo, Martins, 1962, p. 21.

27 T. W. Adorno, Filosofia da nova música, São Paulo, Perspectiva, 2004, p. 51. Na extraordinariamente fecunda primeira parte do ensaio de Gilda de Mello e Souza sobre Macunaíma, é proposta, como se sabe, uma interpretação da estrutura do livro a partir da reflexão sistemática de Mário de Andrade sobre as normas compositivas do populário musical brasileiro, reflexão presente em diversos textos, como o Ensaio sobre a Música Brasileira (1928), dirigido especialmente aos compositores eruditos comprometidos com o modernismo nacionalista. Essa obra põe à disposição um amplo conjunto de elementos e mecanismos criadores constantes da produção folclórica a serem seriamente estudados e assimilados de modo a se poder chegar a uma solução brasileira para a produção individual, que, se inicialmente resultaria intencional (fase em que Mário de Andrade colocava aquele segundo período modernista), tendia, conforme a organicidade na relação com o 
material popular, a ser música inconscientemente nacional, ou arte autônoma, purificada de fins - e de magia, acrescentamos, autorizados pela observação do Autor de que o fetichismo de Canaã seria mais brasileiro e útil que a poesia de Oswald, presumidamente livre de obrigações quando ainda não era chegado o tempo para isso. Não é minha intenção agora discutir esse juízo inflamado; chamo apenas a atenção para o fato de que a nação é, desse ponto de vista, um elemento que embaraça e subordina a arte como o ritual mágico ou o culto religioso. Se a missão social do artista não é mais uma evidência para ele a partir do século 19, para o modernista deveria ser um princípio não problemático. Nesse ponto não havia ruptura alguma com o empenho de construção nacional que, segundo Antonio Candido, caracteriza a literatura brasileira desde a Independência. Para uma excelente análise da especificidade do senso de missão patriótica em Mário, que, se conserva muito da herança romântico-naturalista, com toda a sua carga de determinismo racial e geográfico, a relativiza por meio da psicologia da criação, cf. as páginas iniciais do artigo de Vinicius Dantas “Entre ‘A Negra’ e a Mata Virgem” (revista Novos Estudos CEBRAP, São Paulo, julho/1996, n45).

Voltando: no estágio de inconsciência adquirida, a "racialidade", ou o caracteristicamente brasileiro, já teria deixado de ser programa para virar imanência, segunda natureza. Não seria ainda o caso do modernismo, avalia o Autor.

Entre as formas fixas recenseadas no Ensaio, estão a suíte e a variação, comuns tanto à música erudita como à música popular e sublinhadas por Gilda porque seriam fundamentalmente elas, conforme sua hipótese bem fundada e comprovada, as normas de compor reativadas para a criação de Macunaíma, designado desde a segunda edição como rapsódia, gênero de estrutura heteróclita e aberta, também referido por Mário como processo criador tradicional da coletividade anônima, semelhante às formas corais. A suíte, de natureza também fragmentária, consistiria em "uma união de várias peças de estrutura e caráter distintos, todas de tipo coreográfico, para formar obras complexas e maiores. Este processo rapsódico foi muito difundido no Romantismo e entre nós tornou-se como que um hábito nacional. Ocorre nas rodas infantis, onde as crianças costumam juntar um canto com outro, 'chegando mesmo a fixar suítes com sucessão obrigatória de peças'; permanece mesmo nos hábitos suburbanos, ressurgindo no costume - talvez de importação - de arrematarem os bailes com a junção de várias peças diversas. São formas primárias de suíte todas as nossas principais danças dramáticas: os fandangos do Sul paulista, os cateretês do Centro brasileiro, e no Nordeste os caboclinhos (...)", entre outros, como o bumba-meu-boi (O tupi e o alaúde, pp. 13-14). Quanto ao princípio da variação, trata-se "de uma regra básica de compor e consiste [de acordo com a definição de Mário] em 'repetir uma melodia dada, mudando a cada repetição um ou mais elementos constitutivos dela de forma que, apresentando uma fisionomia nova, ela permanece sempre 
desenvolvimento temático. Este viria a dominar toda a forma sonata como o princípio mesmo da subjetividade, cuja expressão implicava o aniquilamento de envelhecidas convenções, destituídas da função organizadora que possuíam no classicismo. A reconstrução da totalidade da obra, tornada problemática, constitui a principal tarefa - solucionada de maneira diferente conforme o nível histórico do material musical disponível - com a qual terá de se haver a linhagem iniciada por Beethoven e superada (aufgehoben...) pela Música Nova ${ }^{28}$. Com o Romantismo, a variação passava a interferir na estrutura do material que lhe servisse de base, o qual deixava de ser em si para ser em relação. Ele passa a estar à disposição do sujeito. Sua conservação depende de sua modificação: “Tudo é sempre o 'mesmo'. Mas o sentido desta identidade se reflete como não-identidade", o que, porém, coloca a música sob a ameaça cada vez maior do vazio temporal. Em Schöenberg, a variação domina a obra inteira de tal modo que a dinâmica, pela qual a música aparece como evolução no tempo, se converte em estática ${ }^{29}$. Voltando a nosso Autor, convém assinalar que a questão para ele estava colocada em outro patamar. Numa civilização que mal começava, com enormes carências materiais e culturais, a música evidentemente estivera à margem da tendência evolutiva européia. Esta, porém, não

reconhecível na sua personalidade'. (...) Quando a música erudita - por esgotamento ou por projeto estético - se retempera nas fontes populares, apóia-se sempre na variação, quer utilize as fórmulas rítmico-melódicas do povo de maneira simplória, quer se afaste do seu ponto de partida através de alterações requintadas. No Brasil, por exemplo, no início do movimento nacionalista, os compositores, levados talvez por um 'excessivo característico', limitam-se a retirar do populário melodias inteiras e formas melódicas quase sem alteração; mas num período posterior já procuram partir de certas fórmulas constantes, 'de pequenos elementos rítmicos, melódicos, harmônicos, polifônicos, de timbre, que nacionalizam sem o excesso de popularismo"” (op cit., p. 19).

${ }^{28}$ Adorno, Filosofia da nova música, pp. 50-53.

${ }^{29} I d$., ib., p. 51-52 e 55. 
poderia ser ignorada, mesmo em seu grau mais adiantado. O problema era verificar o que se deveria assimilar dela que ajudasse a fixar, não recalcar, a particularidade brasileira. O modelo que poderia nos guiar sem que recaíssemos em uma "superafetação cultural", conforme uma expressão típica sua, seria algo como Bartók. Neste, sim, encontraríamos um "harmonizador simples, mas crítico" do substrato folclórico ${ }^{30}$, o qual, posto como objeto da subjetividade criadora, tinha a dignidade, mais que preservada, dinamizada a ponto de voltar-se como crítica da cultura.

Diferentemente da música européia em sua linha mais avançada, aqui a subjetividade (o harmonizador crítico) deparava-se com limites à sua expansão. A esse respeito Mário de Andrade tem uma posição bastante clara, mais ou menos inalterável desde pelo menos 1923 até 1945, isso se se considerar que a ênfase no "nacional" passa a se deslocar cada vez mais ao longo de sua produção para o social", já latente no uso que faz do primeiro termo porém ${ }^{31}$. Num artigo sobre

\footnotetext{
${ }^{30}$ Mário de Andrade, Ensaio sobre a música brasileira, pp. 42-44.

${ }^{31}$ Em 1942, a propósito da observação de Curt Lange de que, diferentemente do que ocorria em outros países da América Latina, a música erudita no Brasil continuava a ter um caráter bastante folclorizante, o que a impedia de avançar em direção à "música pura", Mário de Andrade replica que talvez entre nós o problema fosse outro: "No Brasil está na criação da música erudita o problema do distanciamento social. Encarados sob o ponto de vista do distanciamento social (...), os nossos compositores maiores da atualidade, todos se afirmam resolutamente socializantes em sua atitude criadora. Carece verificar, com maior certeza de visão, que o fato dos artistas eruditos darem a suas obras caracteres mais populares, maior delícia melódica, mais dinamização rítmica, maior parecença com os cantos tradicionais do povo, não é apenas uma questão de nacionalismo. É também e mais efetivamente uma tendência para diminuir anti-capitalistamente, a distância social hoje tão absurdamente exagerada, entre a arte erudita e as massas populares". E mais adiante: "Entre, nós, no Brasil, creio que foi Sérgio Milliet quem primeiro e com maior insistência chamou a atenção para o fato do distanciamento social entre a arte contemporânea e as massas populares. Esse distanciamento
} 
atingiu tal e tão abstruso exaspero que é muito difícil estabelecer que função artística (não falo função 'estética', mas exatamente 'artística') podem exercer as criações exacerbadamente 'hedonísticas' de um Léger na pintura, de um Schoenberg na música, como de um Joyce na literatura (...). Positivamente a arte é outra cousa, sempre foi outra cousa e tem de voltar ao que foi. Arte é uma forma de contato, é uma forma de crítica, é uma forma de correção. É uma forma de aproximação social” ("Distanciamentos e aproximações”, Música, doce música, Belo Horizonte, Itatiaia, 2006, pp.351-354, grifo meu). Não teríamos direito à autonomia da forma moderna, em que Mário pressentia uma tendência crescentemente anticomunicativa e suicida, deletéria, portanto, para uma cultura ainda tão rala. A racionalidade dodecafônica se lhe afigurava hiperindividualista, o que Adorno, por exemplo, não contrariaria. "O sujeito da nova música, que ela registra fielmente, é o sujeito real, emancipado, abandonado a seu isolamento no último período burguês". Ocorre que, ainda segundo essa análise, a música nova documenta e fixa tão radicalmente a subjetividade que esta se converte em objeto, razão por que, em certo sentido, não haveria oposição entre expressionismo e objetivismo: "A música expressionista havia tomado com tanta exatidão o princípio da expressão da música romântica tradicional que ele assumiu o caráter de documento. Mas ao mesmo tempo o inverteu. A música como documento da expressão já não é 'expressiva'” (op. cit., pp. 52 e 46). Do lado de cá, passaria em brancas nuvens esse processo em que a subjetividade, hipostasiada, propicia a objetivação estética a ponto de a autoridade do compositor em relação ao material se transformar em determinação do próprio material, o qual se impõe como norma. Faltava-nos todo o processo histórico-formal e sua dialética. Contudo, se o expressionismo pôde se revelar objetivismo, por razões simetricamente opostas Mário de Andrade pedia cautela tanto com a desenvoltura do sujeito como com a racionalidade construtivista, o que dá em certo ponto identidade aos termos e promove uma curiosa dialética, em baixa rotação, que eu diria subespécie da primeira. A prevenção podia ser explicada pelo nível da produção material, que não dispunha da alta técnica capitalista, e pelo longo passado escravista, que abriu um fosso sempiterno entre as formas culturais importadas e praticadas pela elite e a vida do resto da população, em relação à qual aquelas formas flutuavam longe e não enraizavam. De que sujeito viria a désinvolture já que o Modernismo, ou os seus representantes mais radicais, tinha se colocado a tarefa de incorporar todo o Brasil a cada frase? A importação dos meios expressivos da vanguarda podia ser algo facilmente comandado pelo consumismo novo-rico. Em 28, no Ensaio, o Autor, tomando os termos de Bandeira em relação a sua primeira poesia, "especificaria" o elemento autóctone: "Um ruim esquisito vago, mas geral” (op. cit., p. 17). Para configurar essa présubjetividade, ele propôs isolar como categoria um momento da dissolução do sujeito burguês, sem acompanhá-la até o fim. O fim não nos dizia respeito, poderia levar o nosso "esquisito" com a água 
do banho. Cabia-nos aproveitar o instante em que o eu já não era mais idêntico a si mesmo. Veja-se que o expressionismo em Macunaíma carece de estranhamento; o eu não está isolado e esvaziado de mundo, mas se mistura à paisagem ainda não totalmente tecnificada. Os choques traumáticos que vivencia o corpo diante da máquina, conforme a teoria de Benjamin, estão aqui amortecidos pelo folclore (lembremos, por exemplo, a etiologia do automóvel a partir da transformação da onça palauá, Macunaíma, pp. 129-132). Compare-se essa obra com um romance bem contemporâneo como Berlin Alexanderplatz (1929), de Döblin, para aquilatar a diferença (não digo de qualidade artística). Mas, corrigindo minha formulação, os choques não estariam propriamente amortecidos. Na verdade, a vivência do corpo é que carece de vocabulário - ainda que São Paulo não fosse Berlim, o Brasil sempre foi um país de contrastes, e, para quem vinha dos cafundós, como Macunaíma, bondes elétricos, carros, vitrines, elevadores, multidão, alguma verticalização já deviam assombrar um bocado. Como diria o Autor em 32, por ocasião da Revolução Constitucionalista: "De fato, há uma distinção intransponível por enquanto entre São Paulo e o Brasil. É que são duas civilizações diversas. O Brasil é uma... não chega a ser uma civilização, é uma precariedade (...). São Paulo é uma civilização européia cristã (...) (apud Carlos Eduardo Berriel, Dimensões de Macunaíma, Tese de Doutorado, Unicamp, 1987, p. 141). Franz Biberkopf pode sentir exatamente a solidão na metrópole porque ela já fora o palco de possibilidades concretas de solidariedade e emancipação de sua classe. Com a morte de Rosa Luxemburgo e Karl Liebknecht (mencionada residualmente nas falas de bar), esse laço foi rompido. Penso que remonta à vitória da social-democracia alemã a razão para os personagens, agora mais lumpens que proletários, moídos pela inflação, andarem sem rumo, caírem no crime, se levantarem, caírem de novo. O romance de Döblin é realmente um romance sobre coisas (matadouros, guindastes, metrô, noticiários, publicidade, luminosos etc.), e não mais sobre homens. O diagnóstico de Lukács em "Narrar ou descrever" se aplicaria aqui à perfeição (independentemente do juízo que ele faz do diagnosticado): a descrição fetichista dos objetos pôde empurrar a narração para o segundo plano devido ao distanciamento da prática política. Na obra referida, a descrição se transforma qualitativamente em montagem. As coisas se apresentam quase sem vínculo épico. Biberkopf passou a ser um rosto desfigurado, e a cidade grande rouba a sua cena. Por sua vez, o choque do imigrante nortista que Macunaíma (como Chico Antônio, o emboladeiro pessoalmente conhecido por Mário e a quem este tornaria protagonista, fazendo vir para o Sudeste no romance Café, iniciado em 29, e depois em Vida do cantador) é em certa medida vem processado em termos fabulares, o que amacia aquele elemento terrífico da alienação no expressionismo e ao mesmo tempo indica que não se trata de um indivíduo, no sentido moderno do termo. Temos um acesso muito mediado à violência traumatizante (mais que isso: mortífera) que um título como O homem que virou 
Luciano Gallet, assinala que, conquanto lhe aprove a harmonização moderna de canções populares, inseridas numa "entidade culturalmente mais elevada", nem sempre ela parecia justificável: "Algumas harmonizações dele são complicadas, pesadas por demais. Ricas por demais. Vem daí uma sensação de roupagem 'nouveau-riche' que me desagrada bem. (...) Carece lembrar que refinamento não exclui simplicidade. Bela Bartok harmoniza refinadissimamente e no entanto dentro duma simplicidade perfeitamente equilibrada com a própria essência das canções populares que transporta pra ordem artística. As harmonizações dele são moderníssimas e, no entanto, perfeitas, a meu ver" ${ }^{32}$. A equação aqui recomendada

suco indicaria com toda a clareza algumas décadas depois. Mas a clareza da frase, cuja hipérbole no entanto lhe dá ressonâncias folclóricas (de modo semelhante Macunaíma foi literalmente partido em milhares de torresminhos), seria obrigada por um nível bem mais avançado de industrialização e urbanização.

A personagem Fraülein Elsa, de Amar, verbo intransitivo (1927), foi uma tentativa muito interessante, mas fracassada, de transpor a estética da revista Der Sturm. De todo modo, o fato de a personagem ser uma alemã propiciava essa aplicação sem grande cerimônia. É verdade que o autismo de Elsa exprimia uma certa experiência local; ficava, entretanto, com muita barriga em contraste com os pitorescos Sousa Costa e suas quatro crianças.

32 "Luciano Gallet: 'Canções brasileiras”" [1927], Música, doce música, p. 164. Cf., ainda, o artigo "Henrique Oswald” [1931], para contemplar no seu todo o juízo do ensaísta sobre a harmonização erudita. O refinamento harmônico, diz, não é "antinacional", conforme a concepção de muitos músicos, análoga à "mentalidade paupérrima de certos poetinhas de metáforas modernas, que por falar em saci e no maxixe, o Brasil eram eles. Não é. O Brasil será o que todos nós fizermos dele (...)" (p. 159).

Embora, na Filosofia da nova música, Adorno estivesse voltado para o que considerava o estágio mais adiantado da consciência estética (Schöenberg) e para as tentativas de "retorno à ordem" (Stravinski), pôde justificar e admirar a permanência do tonalismo em certos contextos. Seria o caso exatamente de Bartók e Janacek: "Naquelas esferas em que a tendência evolutiva da música ocidental não se impôs completamente, como em alguns territórios agrários da Europa Meridional e Oriental, pôde ser empregado sem desonra, até o passado mais recente, um material tonal. Basta pensar na arte 
de popular e moderno não deixa de ser uma variante da combinação simples, mas crítico formulada na mesma época. Luciano Gallet não seria etnógrafo, mas um artista, e em sua obra "a "colher torta' do criador mexe o virado"33. A margem de individualidade, porém, deve ser controlada pelo material recolhido sob pena de este perder a fisionomia original e aquela se falsear. O hiperindividualismo, que Mário identificava como uma "constância nacional", resultava em ausência de pauta pela qual se guiasse o compositor interessado em contribuir para a sistematização de uma música "endógena". As soluções encontradas geralmente não prosperavam nem se tradicionalizavam (um termo caro ao Autor), o que teria alimentado entre nós uma

de caráter regional, mas grandiosa em sua coerência, de Janacek, e também em boa parte da música de Bartók, que, com toda a sua inclinação ao folclore, representava simultaneamente parte da grande música européia mais avançada. A legitimação desta música 'um pouco à margem' se encontra sempre no fato de que ela dá forma a um preceito em si mesmo exato e seletivo. À diferença das manifestações da ideologia do sangue e do solo, a música realmente regional, cujo material em si fácil e corrente está organizado de maneira muito diferente da ocidental, possui uma força de estranhamento que a aproxima da vanguarda e não da reação nacionalista. De certo modo sai de fora em auxílio à crítica musical imanente da cultura, tal como esta se expressa na música radical moderna (...)”. Cf. Filosofia da nova música, pp. 37-38n (grifos meus). Bastante diferente e problemática para o autor era a "selvagem representação do selvagem" em Stravinski. Para um estudo amplo da semelhança de tarefas com as quais tinham de se haver Mário de Andrade e Bartók, cf., de Elizabeth Travassos, Os mandarins milagrosos, Rio de Janeiro, Zahar/Funarte, 1997.

33 “Canções brasileiras”, Música, doce música, p. 162. 
noção equivocada de originalidade e de plágio $^{34}$. Na verdade, o que ele chama de hiperindividualismo é antes "erudição falsificadora", a roupagem "nouveau-riche" referida acima - busca-se afirmar a si mesmo, mas o si-mesmo não é ele, e sim a tendência prestigiosa do momento, que o encobre. E aqui a serpente morde a própria cauda, ou seja, nada de novo acontece, pois, quanto mais a individualidade se impõe, mais escamoteia a si mesma ${ }^{35}$. De onde derivar a possibilidade de ocorrer alguma subjetivação? Todo o cuidado é pouco, parece dizer Mário, especialmente em se tratando de música e artes plásticas de expressão erudita, que no Brasil não tinham tido propriamente história, mas pré-história. A respeito do uso que Gallet faz da dissonância, nota que, se na maioria dos casos, é adequado e realça certos aspectos das melodias primitivas, em outros produz mais uma vez a inevitável sensação de "arrebicamento "nouveau-riche"". Mas esse arrebicamento tem excelente efeito quando trabalha pela comicidade e destaca, p. ex., o "pernosticismo mulato bem carioca" já pertencente à obra a ser elaborada. O pernosticismo fica enquadrado pela harmonização sofisticada demais, que o imita. Portanto, se é imitação da imitação, se o ridículo mais modernizado (mais dissonante) de uma mostra o ridículo da outra, que, por sua vez, o reflete, fica tudo bem - "como se vê, isso é obra de criação legítima, porque o mulato seresteiro entoando essa cantiga, jamais não teve a

${ }^{34} \mathrm{O}$ compositor é original quanto mais recusa as soluções precedentes; é plagiador se lhes dá continuidade, se as aproveita, se as supera mas conserva. Conforme o argumento do Autor, trata-se de "um individualismo que não é libertação, mas inculta vaidade", a qual impede a normalização de processos. Chamam de plágio o que seria apenas aproveitamento sistemático (Ensaio, p. 70). Enfim... Mário de Andrade mesmo foi chamado de plagiador por conta de Macunaíma. Veja-se a carta "aberta" a Raimundo Morais, na qual diz que ele copiou, sim, mas seu nome, individual, único, estava lá, ninguém tirava (in Macunaíma, p. 427).

${ }^{35}$ A importância dessa questão em Mário de Andrade foi identificada apaixonadamente por Anatol Rosenfeld. Ver “Mário e o cabotinismo”, in Texto/ContextoI, São Paulo, Perspectiva, 1996. 
intenção de fazer peça cômica. Ele está convencido de que geme de verdade.//(...) porém nas outras[cantigas] como a comicidade não existe, o pedantismo fica sozinho" 36 . Nestas, o gabarola de fundo, que o compositor ironizava através do arremedo harmônico, vem para o primeiro plano, torna-se o próprio Gallet, inconsciente de sua bazófia. Por onde se vê que as mesmas tentações podem andar pelo campo erudito e pelo campo popular, podem pegar desprevenidos os forros e os finos. Tanto é assim que, no imbróglio socioistoricolingüístico que é a "Carta às Icamiabas", o mesmo tiro pode pegar a afetação de um Catulo Cearense e a de muitos colaboradores da Revista de Língua Portuguesa. E provavelmente a do Autor também ${ }^{37}$.

Tomei essa observação sobre a dissonância por ser ela "o meio extremo da subjetivação romântica",38, o que, em um contexto histórico diverso, desgarrada da fundamentação lógica de que derivou, talvez acabe por represar a expressão, ou então por indicar, burlescamente, que a nossa expressão é... a impostação. Mas não é bem assim a avaliação de Mário, pois, como ele mesmo sublinhara, em muitas das reelaborações de Gallet ela estava conforme ao parâmetro harmônico das melodias populares brasileiras, não as descaracterizando portanto. Afinal a dissonância não era tão-somente propriedade da música mais complexa. Ou melhor, ela não apenas

\footnotetext{
36 “Canções brasileiras”, op. cit., p. 165.

${ }^{37}$ Parece bem razoável o comentário de Cavalcanti Proença: “A 'Carta pràs Icamiabas' é o ônus a que se sujeitam todos os escritores brasileiros que, intencionalmente ou não, escreveram em linguagem de sua terra. Tem correspondentes nas Sextilhas de Frei Antão, de Gonçalves Dias, nos diálogos caprichados da primeira parte das Minas de Prata, de Alencar, no Cantar de Amor, de Manuel Bandeira...” (Roteiro de Macunaíma, p. 173). Ou seja, esse ônus é justamente não escrever em linguagem da sua terra e demonstrar "conhecimento da língua antiga".

${ }^{38}$ Filosofia da nova música, p. 53.
} 
era mais avançada que a consonância como podia aludir a um estágio anterior a essa convenção e ser coisa de gente iletrada ${ }^{39}$. Como as manchas na pintura moderna, a atonalidade teria algo de infantil e selvagem - um progresso que, buscando se desembaraçar da rede de compromissos da cultura, é em certa medida regressão, liberação do instinto ${ }^{40}$. Desse ponto de vista, o "desrecalque localista" de que fala Antonio Candido a propósito do modernismo coincide em pontos com a dessublimação na vanguarda; mas este relaxamento vem no curso da autonomização de formas longamente gestadas. Foi o que ocorreu com a dissonância, consequiência inevitável e racional da emancipação do acorde. À falta dessa dialética históricoformal, mas dispondo, como matéria, de uma sociabilidade que não se fizera à custa de fortes repressões do instinto ${ }^{41}$, a técnica vanguardista tanto podia dar expressão

\footnotetext{
${ }^{39}$ Como na ars nova florentina. Adorno, op. cit., p. 41. Leia-se ainda o seguinte trecho: "Talvez a emancipação da dissonância não seja, na verdade, como ensina a história oficial da música, o resultado da evolução do romantismo tardio pós-wagneriano, mas a propensão a ela acompanhou como um hemisfério escuro toda a música burguesa, desde Gesualdo e Bach, e pode ser comparada talvez com a função que na história da ratio burguesa tem ocultamente o conceito de inconsciente. $\mathrm{E}$ aqui não se trata de uma simples analogia, mas a dissonância foi desde o início veículo de tudo aquilo que devia ceder ao tabu da ordem." (id.., p. 124n.). Referindo-se à ars nova de um modo geral, Mário observa que a polifonia católica entra em incubação e os compositores passam a ser "profundamente influenciados pelo trovadorismo e pela arte popular" (Pequena história da música, São Paulo, Livraria Martins, 1977, p. 52).

${ }^{40}$ Adorno, op. cit., p. 41.

41 Lembre-se, por exemplo, a comparação que Antonio Candido fez, no ensaio "Dialética da malandragem", entre a sociedade puritana transposta em A letra escarlate e a sociedade que não exclui a desordem de seu funcionamento normal em Memórias de um sargento de milícias. Pode-se perguntar se o regime escravista não significava uma forte repressão libidinal. Talvez nem tanto da libido como dos escravos. Ou melhor, a resposta depende de saber que classe e gênero tinham o instinto reprimido e o que convinha reprimir. A escravidão esteve liberada pelo regime do instinto dos proprietários.
} 
ao irracionalismo, com o que contribuía para delinear nossa experiência, como the sobrepor racionalidade demais, e o resultado podia ficar fora do bom senso... Nosso primitivismo objetivo corria o risco de ser engolido por abstrações um tanto flutuantes, não motivadas internamente. Resultado, porém, que não deixava de ser bem brasileiro, ou colonizado, pois era como o pernosticismo atualizado na música moderna, mas isento de ironia, das composições malsucedidas de Gallet. Para romper com essa patologia, o crítico pedia antes ou a exposição minuciosa e distanciada desse comportamento - a "capacidade de fotografar a estupidez" ${ }^{42}$-, caso em que o compositor caçoava do músico cheio de circunstância, ou o realce das particularidades do material colhido, de que o primeiro caso não deixava de ser na verdade uma subespécie. E aqui voltamos à técnica da variação. Como Marx e Engels, Mário e, é preciso acrescentar, Oswald de Andrade pareciam achar que "nada era mais ridículo que uma idéia desvinculada de interesses concretos". Sem pretender comparar as dobradinhas, o que seria um disparate por muitas razões, há porém um elemento que as vincula - o choque de realidade a que submeteram a tendência idealista de sua cultura. Mas essa tendência se manifestou de maneiras muito diferentes nos dois casos, e essa é uma das razões que tornam a comparação em boa parte descabida, pois toda a tradição do idealismo alemão até os jovens hegelianos era, em primeiro lugar, uma tradição interna, e de matéria e densidade tal que pôde fornececer as categorias para a sua poderosa crítica. Entre nós, a referida tendência idealista tomou em geral a forma da "idéia fora de lugar", ou ainda, da "superafetação cultural", se quisermos ficar, como Mário, apenas no campo da

\footnotetext{
${ }^{42}$ Conforme suas próprias palavras ao identificar uma das qualidades do primeiro livro de poemas de Oswald de Andrade. Cf. "Osvaldo de Andrade"[1924], in Marta Rossetti Batista, Telê Porto Ancona Lopez, Yone Soares de Lima (org.), Brasil: $1^{a}$ tempo modernista, São Paulo, IEB, 1972, pp. 222.
} 
cultura (o esquema conceitual de Roberto Schwarz dá um passo muito superior em abrangência e sistematização desse problema). Ou seja, nossa irresistível inclinação para fugir ao enfrentamento do cotidiano se apoiava em "importações acomodatícias e irregulares" Creio não oferecer dúvida que a dita pulsão não fosse de caráter fisiológico ou psicológico-racial, mas histórico-social - e aludia a cada investida às forças conservadoras que definiram, em todos os momentos decisivos após a Independência, o tipo de modernização adequado para o país. Esta mesma autorizava à versatilidade estilística e ao que Schwarz denominou "lepidez ideológica”. A razão, porém, para que Mário não se ligasse ao proletariado e nele escorasse a sua reflexão e criação como em bolas de chumbo que as impedissem de levitar, propiciando desse modo uma reversibilidade aqui inaudita entre teoria e prática, é algo que não sei se se atribui a sua presença ainda muito parcial no conjunto da sociedade, a sua composição majoritariamente exógena e portanto desligada da história nacional pregressa ${ }^{44}$, ou à falta de engajamento que sempre caracterizou o escritor brasileiro, falta que, por sua vez, se vincula às razões

\footnotetext{
${ }^{43}$ Mário de Andrade, "O Aleijadinho" [1935], Aspectos das artes plásticas no Brasil, São Paulo, Livraria Martins, 1965, p. 45.

${ }^{44}$ Conforme Luiz Felipe de Alencastro, ganha fôlego o processo de internalização do mercado de trabalho, que no Brasil sempre fora exógeno, obtido via tráfico negreiro e tráfico de imigrantes. A manutenção do termo tráfico no segundo caso não seria tão forçada, explica o historiador, se se pensar que a passagem de um período a outro não se fez acompanhar imediatamente das condições jurídicas subjacentes ao trabalho livre. Ver, a propósito, "A pré-revolução de 30", Novos estudos CEBRAP, N.18, setembro de 1987; e "Proletários e escravos", Novos Estudos CEBRAP, n.21, julho de 1988 .
} 
precedentes $^{45}$. Não é minha intenção agora avaliar se foi menos equivocado o nacionalismo de Mário, que se manteve na linhagem romântica de pesquisa do

${ }^{45}$ Nas palavras de Paulo Arantes, houve engajamento no sentido da "tradição empenhada" na construção nacional, e não engajamento para alterar as relações de produção.

A partir de 30, um caráter mais político que economicista ou reformista se evidenciaria nas organizações sindicais então, menos marcadas pelo anarco-sindicalismo como o tinham sido até então (cf., a esse propósito, de Ricardo Antunes, Classe operária, sindicatos e partido no Brasil, São Paulo, Ensaio/Cortez, 1988). As tentativas de aproximação da realidade empreendidas pelo primeiro modernismo seriam passíveis de ser criticadas, e Oswald o faria depois de sua filiação ao Partido Comunista: "Eis porém que o parque industrial de São Paulo era um parque de transformação. Com matéria-prima importada. Às vezes originária do próprio solo nosso. Macunaíma. A valorização do café foi uma operação imperialista. A poesia Pau-Brasil também. Isso tinha que ruir com as cornetas da crise. Como ruiu quase toda a literatura brasileira 'de vanguarda', provinciana e suspeita, quando não extremamente esgotada e reacionária. Ficou da minha este livro. Um documento. Um gráfico. $\mathrm{O}$ brasileiro à toa na maré alta da última etapa do capitalismo Fanchono. Oportunista e revoltoso. Conservador e sexual” ("Prefácio” [1933], Serafim Ponte Grande, São Paulo, Globo, 1990, p.38). No prefácio de 1926, Oswald já dissera: "No mundo atual, Serafim traz duas razões: o bom câmbio e a ignorância audaz" (“Objeto e fim da presente obra”, op. cit., p.33). A audácia e o frescor modernista vinham na crista da alta do café, e não do termômetro da consciência do proletariado. Em 1933, o criador da poesia pau-brasil iria se dizer "enojado de tudo. E possuído de uma única vontade. Ser, pelo menos, casaca de ferro na Revolução Proletária” (id., p. 39). A passagem do nacional para o social revela que Mário, por seu turno, sentiu que a hora do nacionalismo estava fanando. Assim como analisou o modernismo nacionalista na música, p.ex: "Perseveramos musicalmente coloniais até que a convulsão de 1914, firmando o estado de espírito novo, ao mesmo tempo que dava a todos os países uma percepção por assim dizer objetiva da tonalidade do universo e despertava no homem uma consciência mais íntima de universalismo, também evidenciava as diferenças existentes entre as raças e legitimava em todos os agrupamentos humanos a consciência racial" (Pequena história da música, p. 163) - compreenderia os embaraços em que essa consciência, depois de 30, se achava: "Justo o contrário do mal-estar de agora, em que as diferenciações e oscilações de progresso econômico e o internacionalismo do proletariado nascente, deram origem a um verdadeiro engurgitamento da consciência nacional. De que nós os modernistas de 1922, não deixamos de ser um bocado vítimas também...” (“O Aleijadinho”, in op. cit., p. 22). 
material popular - a aprimorando e limpando de muitos preconceitos, contudo - ou a virada internacionalista de Oswald, para quem, sob a influência de Patrícia Galvão, se tornara foco de preocupações políticas e portanto de representação literária o parque industrial, independentemente de este ser composto por italianos forasteiros ou pardos autóctones ${ }^{46}$. Chamo apenas a atenção para a luta, em ambos os casos e já desde a década de 20 , contra a flutuação da cultura em relação ao funcionamento da vida concreta e especialmente da vida dos oprimidos. Essa correção nosso Autor a foi buscar nos mecanismos criadores da imaginação popular, entre os quais se destaca a variação, cujo "processo parasitário de compor" foi identificado por Mário como próprio dessa imaginação e tinha seu melhor exemplo no improviso do cantador nordestino. Deste ele forneceria uma admirável descrição em "O canto do cantador" $(1944)^{47}$. Aqui variação é manifestamente individualização; ela ocorre primeiro de maneira inconsciente e para suprir as falhas na memorização da melodia tradicional. Ao ser reproduzido esse tema incompleto com variações, um novo esquema vai se fixando e por fim se despe dos elementos substitutivamente acrescidos. O compositor passa a cantar diversas vezes a linha vulgar ("no sentido mais elevado e etimológico do termo vulgar") que se estabeleceu. Em seguida, "atingindo outra vez a possessão", glosa o esquema destilado, com consciência

\footnotetext{
${ }^{46}$ Não que as opressões no parque industrial paulista não recebessem então a atenção de Mário; para prová-lo, bastaria recorrer apenas aos Contos de Belazarte, ou ao depoimento de Macunaíma na Carta sobre os italianinhos, "destinados a alimentarem as nossas fábricas de áureos potentados, e a servirem, escravos, o descanso aromático dos Cresos” (Macunaíma, p. 83).

${ }^{47}$ Um dos seis artigos publicados em sua coluna "Mundo Musical", na Folha da Manhã, a propósito de Vida do cantador, ficcionalização "em seis lições" da vida do compositor potiguar Chico Antônio. Apud Gilda de Mello e Souza, O tupi e o alaúde, p. 22-23; cf. Vida de cantador, edição crítica de Raimunda de Brito Batista, Belo Horizonte/Rio de Janeiro, Villa Rica, 1993, pp. 89-90.
} 
agora, isto é, não para cobrir algum déficit, mas para lançar o canto novo. Esse momento de afirmação do improvisador em relação ao tema fundamental empolga menos a platéia pela dificuldade na apreensão de seus arabescos e por sua menor dinamogenia: são os cantos "mais simples, mais desnivelados, mais puros, que exercem a verdadeira fascinação sobre o povo (...). Os outros mais complicados e virtuosísticos dão ao povo um entusiasmo muito mais individualista e descoletivizado..."48. A linha vulgar socializa; a linha vulgar restituída à fantasia do músico dessocializa. No entanto mesmo a primeira é resultado, no referido e sempre individual processo de improvisar, de flexões preliminares e, portanto, de uma relativa individualização, embora inconsciente. Podemos então perguntar se, por sua vez, a segunda linha, descoletivizadora pela individualização, pela variação agora deliberada, seria construída de cor, ou seja, seria falsamente subjetivadora. Não é bem assim. Creio que Mário reconhece como um pouco diferenciados o processo de invenção da melodia e o do texto. Gilda de Mello e Souza, apoiada no comentário sobre o improviso dos versos em Vida de cantador, assinala que o método seria o mesmo em um e outro caso, e o canto novo seria uma "traição da memória", isto é, seria apenas aparentemente novo, pois, tal como o repentista, que diz de cor o que imagina estar inventando, o compositor se ilude de que produz uma versão nova ${ }^{49}$. Acho, porém, que o Autor atribui à traição de memória apenas a fatura dos poemas, à vista do fato de que o repertório de versos-feitos, frases prontas e outros enchimentos mnemônicos é imenso, as idéias restritas e os improvisadores em geral

\footnotetext{
48 “O canto do cantador", op. cit., p. 90.

${ }^{49}$ O tupi e o alaúde, p. 25.
} 
analfabetos $^{50}$. Mesmo em relação aos versos de Chico Antonio, muito embolados e de efeito surrealista, ele é obrigado a conceder que "a sensação primeira era dum mundo mirífico de milagrosas imagens, mas logo a análise demonstrava os andaimes daquilo tudo. Verificação que deixo aqui não como censura nem pejorativo. Como verificação apenas" ${ }^{\Perp 1}$. Talvez a crítica, tendo reproduzido e analisado o comentário do escritor sobre a variação musical, veio a igualá-lo em disciplina e consecução ao processo poético por uma espécie de lapso, que lhe forneceu de todo modo a passagem para chegar a Macunaíma, literatura afinal, e não música. E, sem dúvida, independentemente da distinção que Mário parece (parece, pois ela não é explicitamente mencionada, e posso ter lido mal) reconhecer no nível adquirido por ambas as instâncias de improviso, nas quais um cantador peleja ao mesmo tempo, ele deve tê-las igualmente assimilado e ativado na construção do livro. Razão pela qual fora inútil o lapso e por certo o reparo que fiz, pois, ao fim e ao cabo, concordo inteiramente com a intuição e conclusão de Da. Gilda. Mas, se adverti que talvez a prática literária popular não coincidisse em todo passo com a musical, é que aquela sempre esteve na rabeira deste, que já antes da Independência dera produtos originais em relação aos modelos ultramarinos ${ }^{52}$. Foi na música e nas

\footnotetext{
${ }^{50}$ Vida de cantador, p. 84. Como ressalva o Autor, "esta traição de memória não sucede só com gente inculta mas com todos nós escritores e poetas. É um dos nossos perigos constantes. //O cantador nordestino não só decora romances da literatura de cordel, mas também os desafios, as pelejas. O coqueiro também, e é mesmo desagradável a gente observar que, tendo mais ocasião de entoar quadras, é raríssimo ele inventar uma” (p. 84).

${ }^{51} I d$., ib., p. 85.

52 "Quanto à influência européia, é natural que seja enorme em nossa música tanto popular como artística. Portugal e Espanha primeiro, em seguida mais a Itália e a Alemanha, forneceram o principal contingente de sangue na formação da raça brasileira e suas manifestações. A nossa cultura sendo de base integralmente européia, fez com que a nossa música, embora já popularmente possua caráter
} 
artes plásticas, conforme a observação de Mário em mais de uma passagem observação que suponho ser válida até hoje -, que pôde se exercitar artisticamente "a classe servil numerosa, mas livre" ${ }^{, 53}$. Leia-se, a propósito, esse excelente comentário sociológico :

Os mulatos não eram nem milhores nem piores que brancos portugueses ou negros africanos. O que eles estavam era numa situação particular, desclassificados por não terem raça mais. Nem eram negros sob o bacalhau escravocrata, nem brancos mandões e donos. Livres, dotados duma

nacional enorme, se manifestasse em principal sob as normas da criação européia.// Em nossa música artística, antes da escola moderna, todas as manifestações se ressentiram excessivamente dessa cultura européia a que éramos obrigados." (Grifos meus.) O trecho é claro quanto à diferença no grau de originalidade alcançado pela música popular e pela música erudita. Como se sabe, o autor se desdobrou em estudos sobre os gêneros produzidos pela primeira, entre os quais estavam a modinha e o lundu. Mas sua admiração ia especialmente para os romances, cocos, danças e emboladas, em que "o Brasil manifesta o milhor de sua musicalidade" (cf. "A música brasileira" [1931], Música, doce música, pp. 16-17 е p. 19).

${ }^{53}$ Cf., p. ex., "O Aleijadinho", op. cit., p. 19. Para o crítico as artes plásticas no Brasil não teriam ainda conhecido um período tão brilhante quanto o da segunda metade do século 18 , com as obras singulares produzidas por artistas mulatos da Bahia e de Minas: "Os nossos mestiços do fim da Colônia glorificam a maior 'mulataria', se mostrando artistas plásticos e musicais. (...) Apareceram profetizando para o Brasil uma constância futura genialíssima, especializada nas artes plásticas. Infelizmente isso não passou de rebate falso, uma aurora que não deu dia" (p. 18). Essa aurora se deveu, nas suas palavras, à deformação "sem sistematização possível" da lição ultramarina recebida pelo espalhafato de igrejas que arquitetos e carpinteiros lusitanos construíram em Minas no auge do ciclo do ouro. O trabalho dos mulatos começaria "depois da festa acabada". A respeito da importância dos "inumeráveis 'pardos forros' sem eira nem beira, desambientados, desclassificados" para o amálgama de elementos étnicos na música folclórica nacional, veja-se a resenha "Música brasileira" [1942], sobre livro de Renato Almeida. Segundo tese deste, que o resenhista considera muito plausível, a referida fusão se devia ao fato de os cantadores populares serem em geral mestiços (p. 344). 
liberdade muito vazia, que não tinha nenhuma espécie de educação, nem meios para se ocupar permanentemente. Não eram escravos mais, não chegavam a ser proletariado, nem nada. Soldados. Na mesma disponibilidade do soldado nacioná. (...)// Porque carece lembrar principalmente essa verdade étnica: os mulatos eram então uns desraçados. Raças aqui tinha os portugueses e os negros. Sob o ponto-de-vista social os negros formavam uma raça apenas. Raça e classe se confundiam dentro dos interesses da Colônia. ${ }^{54}$

A frase pode até adquirir a eloqüência titânica de Euclides da Cunha ("os mulatos eram então uns desraçados"), contornar perigosamente os preconceitos de Capistrano de Abreu, Sílvio Romero, José Veríssimo, Aluísio Azevedo e de mais um punhado de pensadores nacionais; mas por fim esconjura a mística determinista, resolvendo de maneira emancipada o termo "desraçado" - que não obstante dói no ouvido. A ênfase cai nos que não ocupavam um lugar definido no funcionamento prático-material da Colônia, em cujos interesses "raça e classe se confundiam". Mas, se acontecia de os mulatos serem "desclassificados", agora no sentido ampliado de brutos, era porque "a classe que desclassifica os homens" condicionamentos desta são vistos com escrúpulo, pois o Autor reconhece que, pela

54 "O Aleijadinho", pp. 19-20.

${ }^{55}$ Id. $i b$. 
força individual, "caráter organizado não era raro entre eles não",56; do mesmo modo, muitos brancos e gente bem-posta podiam ter "alma de "mulato", 57 .

A propósito do momento no improviso musical que Mário chamava de variação consciente, perguntávamos se a individualização em curso era artificial, e o canto novo meramente "traição da memória". Digamos que, retomando o outro fio da meada - a formulação de Adorno referente à variação no Romantismo -, trata-se de "identidade na não-identidade", o que comparamos à equação "simples, mas crítico" do Autor. A individualização ocorre mediante a desidentificação do tema básico, que deixa de ser em si para se tornar em relação ao todo. A estrutura do material é, portanto, modificada, o que se podia acompanhar, no caso do improviso do cantador, já na linha vulgar estabilizada a partir do expurgo das variações inconscientes. Essa linha não era mais o esquema cem por cento tradicional e prévio ao trabalho do músico. Quando este de fato (ou seja, conscientemente) improvisa, o material já foi por ele reconstruído, ainda que o tenha sido para resolver a carência em dominá-lo. Daí termos sublinhado que o repente lingüístico não atingira um tal nível de complexidade - psicológica, inclusive. Por excepcionais que parecessem os versos de Chico Antônio, para continuar no exemplo que mais tirou o sossego de Mário, foram "a liberdade extrema de prosódia e de fantasia rítmica",58, entre outros aspectos musicais, o que lhe teria chamado mais a atenção. Sem dúvida, a poética

\footnotetext{
${ }^{56} I d .$, p. 21.

57 “(...) si compararmos bem a atuação dos mulatos e a dos Fanfarrões Minésios, um Dão João VI, um Pedro I, uma Carlota Joaquina, os poetas coimbrões de Inconfidência, a Diretoria lisboeta da Companhia dos Diamantes, pra só lembrar casos salientes e históricos: será difícil decidir quem que tem alma de 'mulato' entre esses portugas e brasileiros sem firmeza nenhuma de caráter. Mulatos, mais 'mulatos' que os desraçados mulatos da maior mulataria" (“O Aleijadinho", p. 20).

${ }^{58}$ Apud Eduardo Escorel, "O canto da sedução”, in Vida de cantador, p. 20.
} 
popular tomou ao Autor muito tempo de pesquisa, coleta e estudo. Diversas vezes comparou-a à poesia moderna e insistiu que especialmente sua fluidez semântica e vagueza de sentimento não só distinguiam a melhor poesia romântica nacional como deveriam servir de modelo ainda aos poetas cultos, pois formavam um elemento inequivocamente próprio num país "recém nascido da Arte". É dessa perspectiva que criticaria, em 39, a produção do mais famoso condoreiro: "É interessante qualificar de burguesa a coletividade que interessava a Castro Alves. O povo e suas expressões artísticas usam e abusam da fluidez de sentido das palavras. O povo se adapta perfeitamente a frases, estrofes, orações totalmente incompreensíveis. O sentido como o pensamento lógico são expressões de burguesice. A burguesia renega as vaguezas, as evanescências; é anti-musical por excelência, porque não há como a semicultura pra insular a compreensão na terra curta do pensamento lógico" "59. Também sua importante distinção entre tema e assunto faz destes verdadeiras categorias estéticas, com o que verifica o coeficiente de genuinidade lírica na poesia erudita. Castro Alves teria substituído o assunto pelo tema, isto é, exilou dos versos, ao serem escultoricamente enrijecidos, seu valor associativo, o qual a poesia de Fagundes Varela, ao contrário, tinha preservado. Nesta, um elemento de paisagem amplia-se em "mistério psicológico" - no poeta baiano, por sua vez, limita-se a ser mero dado empírico. Nesse sentido, o autor de "Navio negreiro" antecipa o parnasianismo, aliás analisado por Mário em outro artigo: "Dentro da sublime tactilidade com que a palavra nos atinge, será possível, de modo grosseiro, distinguir dois aspectos diversos: a crueza de sentido universal, que lhe dá uma objetividade escultórica, e seu mistério, que lhe dá uma essencialidade musical (...). A impossível impassibilidade parnasiana foi especialmente uma

59 “Castro Alves”, Aspectos da literatura brasileira. 
desconsideração à fluidez riquíssima da palavra, suas sugestões, suas associações, sua música interior e vagueza de sentido pessoal. Pregaram e realizaram o emprego da palavra exata, a palavra concebida como um universo de seu próprio sentido, enfim, a palavra escultoricamente concebida" ${ }^{60}$. A mencionada impassibilidade seria antes afetação cosmopolita - com o urbano alexandrino francês, nossos poetas mais uma vez pairavam uns graus acima da realidade cotidiana. A fluidez da palavra, a não-estabilização do sentido, insistia o crítico, poderiam capturar melhor as peculiaridades de uma formação social e cultural tão pouco definida ${ }^{61}$. A relação

60 "Parnasianismo" (1938), O empalhador de passarinho, São Paulo, Martins/INL/MEC, São Paulo, 1972, p. 10 (grifo meu).

${ }^{61}$ O Expressionismo alemão, cujo estudo Mário fazia paralelamente à sua elaboração de um conceito de nacionalismo, teria fornecido a Mário sobretudo a categoria estética da deformação, na qual vai se apoiar, pois à diferença do Cubismo e do Futurismo, o Expressionismo teria uma orientação social e guardaria profundas afinidades, por meio justamente da deformação e da ênfase em expressões prélógicas, com o gótico, o barroco, a arte primitiva e a popular. Mas os estudos da arte e da literatura alemã e seu empenho em compreender a produção nacional desde o Barroco (veja-se, por exemplo, o uso que faz do expressionismo na análise de Aleijadinho) o levariam a alargar o conceito de expressionismo, que passaria a ser aplicado não só ao movimento estético historicamente localizado, mas também à arte alemã em geral desde o período gótico, em contraposição à arte clássica. Cf., de Gilda de Mello e Souza, "Vanguarda e nacionalismo na década de vinte", in Exercícios de leitura, p. 259. Por meio da cultura e da língua germânica, Mário ainda pretendeu se proteger da onipresença da cultura francesa nas letras e artes nacionais, cultura que ele considerava cosmopolita e definida demais para o Brasil. Segundo Gide (citado por L. Spitzer), "Nous trouvons dans toute la littérature française une horreur de l'informe" - razão pela qual era preciso buscarmos outros caminhos se quiséssemos descrever precisamente o informe. Com espírito parecido ao de Mário e ânimo corretivo, Sérgio Buarque de Hollanda definiria a sociedade brasileira "como um todo incoerente e amorfo", com um quase nada de civilidade e espírito público e muito familismo (Raízes do Brasil, p. 31). É da mesma década o ensaio sobre Álvares de Azevedo "Amor e medo", de certo modo também uma análise do homem cordial na lírica romântica, sobretudo na poesia assustada, familista e um tanto pervertida de Casimiro de Abreu. Nosso Autor sabia que o problema não dizia respeito só à arte 
tema/assunto, fixidez de sentido/fluidez de sentido é recuperada na interessantíssima obra em que resultou o Banquete (1943-1945) e adquire um outro patamar qualitativo na discussão sobre as artes do inacabado e do acabado. O desenho e a música pertenceriam ao primeiro tipo, justamente pelo seu caráter mais aberto ${ }^{62}$. Já na conferência de 42 sobre o Modernismo, avaliava que, além deste, apenas o Romantismo (ou "espírito revolucionário romântico", já presente num Basílio da Gama) não fora "obediência culturalista" e vinha satisfazer demandas perfeitamente locais. Quanto aos outros, seriam “(...) superfectações culturalistas, impostas de cima pra baixo, de proprietário a propriedade, sem o menor fundamento nas forças populares. D'aí uma base desumana, prepotente e, meu Deus! arianizante que, si prova o imperialismo dos que com ela dominavam, prova a sujeição dos que com ela eram dominados. Ora aquela base humana e popular das pesquisas estéticas é facílimo encontrar no Romantismo, que chegou mesmo a retornar coletivamente às fontes do povo e, a bem dizer, criou a ciência do folclore. E mesmo sem lembrar folclore, no verso-livre, no cubismo, no atonalismo, no predomínio do ritmo, no superrealismo mítico, no expressionismo, iremos encontrar essas mesmas bases populares e humanas. E até primitivas, como a arte negra que influiu na invenção e

e, como Sérgio Buarque, tinha intenção progressista. Não obstante creio que, no âmbito estético, insistia nas categorias de fluidez e inacabamento como Goethe dizia: "Se queres chegar ao Infinito,/ tens de ir para todos os lados do Finito". Não se podia saltar por sobre a própria sombra sem cair, ou viajar, em idealismo de segundo grau, bacharelismo, positivismo...

${ }^{62}$ Como observou Gilda de Mello e Souza, nada impede, contudo, que as técnicas de um e outro possam se misturar: assim a música, p.ex., em períodos mais "ditatoriais", pode se reger por técnicas de acabamento, assim como se podem aplicar procedimentos de inacabamento em artes do acabado, como é o caso da escultura. Cf., da autora, "O Banquete", in Exercícios de leitura, p. 43. A fluidez de sentido na poesia popular, por exemplo, eleva bastante seu grau de inacabamento. 
na temática cubista" ${ }^{\natural 3}$. Nosso romantismo literário fora, nos melhores exemplos, "edenicamente analfabeto" 64 . Desse ponto de vista, Macunaíma seria inteiramente filiado a esse espírito romântico, fundamentado nas forças populares - ou mulatas, para voltar ao exposto por Mário sobre o desenvolvimento musical na Colônia.

Numa das "lições" de Vida do cantador, ele também testemunha a facilidade, mencionada no artigo sobre Castro Alves, com que o povo acolhe "frases, estrofes, orações totalmente incompreensíveis". Depois de tirar o canto novo e deixar a voz "fatalizada nas alturas", Chico Antônio, trazendo-a de novo para os "sons normais", parava de chacoalhar o ganzá, "discursava em sons feitos feito louco, engolia palavras pra respirar. Os coristas imaginavam que era a volta do refrão e o iniciavam, mas no zumbido coral esboçado, o coqueiro continuava num texto inventado e sem nexo, multiplicando versos-feitos sobre sertão, despedidas, bois, amor e trabalhos de engenho, numa lucilação sobre-humana em que todo o Nordeste se expandia com fragor. (...) A coisa estava insustentável. Mas porque lhe faltou de repente uma rima, Chico Antônio desembestou pra uma enumeração inconcebível de nomes de engenhos e usinas. E todos o perdoavam. Todos o amavam, é a verdade" $^{\text {"65 }}$. A enumeração descabida é perdoada; mas decerto a complacência do público com esse êxtase individualista já fora preparada pela repetição monótona e

63 "O movimento modernista", in Aspectos da literatura brasileira, pp. 250-251.

64 "O movimento modernista”. Mário de Andrade punha de lado a audácia intelectual e ânsia formativa de Álvares de Azevedo, por quem mostrou grande admiração em “Amor e medo". Embora, em 31, tivesse escrito: "Henrique Oswald foi talvez o mais despaisado, o mais desfuncional de quantos artistas vieram dessa segunda metade do século XIX, e estragaram aquela sumarenta ignorância romântica com que os Álvares de Azevedo e os Cândido Inácio da Silva iam abrasileirando sem querer a nossa fala e o nosso canto" ("Henrique Oswald”, Música, doce música, p. 159).

${ }^{65}$ Vida do cantador, pp. 47-48. 
invariável de um breve coco tradicional, a qual "enfraquecia os corpos num descanso largado e aceitador" ${ }^{\prime 66}$. A enumeração particularizada, comum também à louvação de despedida do cantador, em que este enaltece em pormenor elementos da vida de quem o hospedou, é incluída por Mário entre os "processos individualistas do folclore" ${ }^{\text {67 }}$. É engraçadíssimo o exemplo do romance nordestino, essencialmente uma louvação, em que o autor gaba desde o batente, o tijolo, os caibros da casa que o acolheu até os moradores e seus pertences. Mas toda essa subserviência, a qual compõe a face de "humildade" do cantador, consiste em individualismo tradicionalizado, pois, conforme a nota do etnógrafo, é rebaixamento "sem sofrimento mais, mecanizado, louvando e pedindo dinheiro em ritos fixos e seculares (...)"68. Trata-se de uma usança, tal como a parte de "bazófia", e é semelhante em Macunaíma aos agradecimentos maquinais, ao vezo de brincar com toda mulher que se lhe depare no caminho, de não se furtar jamais a isso para não perder a fama, de fazer discurso, de se espreguiçar, de se pôr a vigiar com um olho aberto e outro dormindo, de bater na cabeça do filho, até achatar, dizendo que ele vá logo a São Paulo ganhar dinheiro, de contar história e catar carrapato, de escarafunchar tesouro enterrado, de seduzir toda companheira do irmão, de se interromper no meio de uma fuga desabalada e calmamente travar conversa com um desconhecido, que pode ser um bicho, um bacharel, um viajante europeu, Padre Anchieta ou outra figura histórica qualquer, menos ou mais remota, mas sempre perdida no tempo-espaço do livro. Sob esse aspecto, o personagem central (como o Gigante, este em grau menor) é uma variedade de papéis colados, em geral

\footnotetext{
${ }^{66}$ Vida de cantador, p. 46.

67 "Bazófia e humildade", in op. cit., p. 78.

68 "Bazófia e humildade", in op. cit., p. 79.
} 
facilmente identificáveis, e não é preciso que tenhamos para isso muito conhecimento de história do Brasil, folclores, teorias do caráter nacional ${ }^{69}$. A cada

${ }^{69}$ Piaimã é uma cristalização de estratos espácio-temporais: sua figura remete ao bandeirante, ao regatão amazonense, ao imigrante italiano enriquecido. Em certo sentido, Venceslau Pietro-Pietra é um concentrado de séculos da história brasileira e tem feição igualmente folclórica. Portanto não é apenas arcaico aquele que vem do remoto Uraricoera. A bem da verdade, a substância arcaica aqui precisa ser relativizada. Basta lembrar que Maanape, o irmão feiticeiro do protagonista, pode se transformar em qualquer máquina, numa espécie de animismo às avessas. Ele pode ser uma smithsson, um aparelho de telefone, um carro. A tecnologia para ele não é um problema; ela também seria movida por espíritos invisíveis. A metamorfose de Maanape em aparelhos se inicia a partir do momento em que Macunaíma descobre o segredo da técnica após uma espécie de reflexão, no fim da qual conclui: "Os homens é que eram máquinas e as máquinas é que eram homens” (op. cit., p. 41). Ela se torna então uma "Iara explicável", e o narrador informa que o personagem se sente livre de novo. O feiticeiro Macunaíma pode atuar também sobre mais essa realidade. Em algumas das narrativas aproveitadas por Mário, entre elas os contos colhidos por Koch-Grünberg, não é incomum a presença de objetos não artesanais (é o caso da árvore de garruchas num mito taulipangue). Pelo estômago do populário podem passar até computadores e tudo bem. Mário utiliza esse mecanismo. Mas, na consideração do personagem sobre a desantropomorfização do homem e a antropomorfização da máquina, o Autor se infiltrou um tanto demais. Não o suficiente para fazer uma reflexão mais profunda, não meramente antitécnica e no final das contas antimoderna (a reflexão de Brecht em $O$ vôo sobre o oceano é bem mais bonita nesse ponto, com as potências da natureza perplexas por não conseguirem derrubar o avião); o bastante, no entanto, para produzir um problema de verossimilhança. Tal problema ocorre também no auto-exame final do herói sobre sua existência sem projeto e quando, por exemplo, ao deixar São Paulo para trás, “enxugou a lágrima, consertou o beicinho tremendo" (Op. cit., p. 136). É Mário de Andrade quem está chorando aqui; rapidamente contudo se contém, e a cena não sai prejudicada. Até porque o "beicinho tremendo" é comovente mesmo e este país parece não ter jeito. Voltando à composição arlequinal das figuras, note-se que Maanape como Macunaíma e Jiguê moram numa pensão. Nesse ponto, são pobres imigrantes. Por outro lado, podem fazer discursos bacharelescos e pedir favores, seja às icamiabas, seja ao governo. Aqui sua situação social já não seria a de imigrantes, mas de burocratas e mesmo artistas. E, acrescentemos ainda, de uma maneira geral o herói é o "Imperador do Mato Virgem". Sabe-se que, sob essa alcunha, há uma inequívoca alusão ao avô de Mário de Andrade, Joaquim Almeida Leite 
papel, ou mecanismo posto em funcionamento, podemos apreciar ora uma classe, um perfil social, um aspecto de cultura ou miséria, tudo, ou quase tudo, que pôde cair na boca do povo daqui, se rotinizar e consolidar em refrão ou adágio - ainda que a cristalização lingüística volte a ser no livro ação e imagem. Assim, por exemplo, conforme uma imagem tradicional do brasileiro, Macunaíma não gosta de pegar no batente, mas gosta de jogar conversa fora. Não obstante um dia, sem razão manifesta, ele se interdita o desejo de contar histórias, pois "quem conta história de dia cria rabo de cotia”. Um juízo categórico, que não dá chance, para prevenir quem gosta de ócio em hora imprópria é enunciado de dentro do maior preguiçoso possível e o decide a ir caçar $^{70}$. Na verdade, ele não vai caçar coisa nenhuma, mas contar uma grande mentira (mais uma) para o pessoal da pensão onde mora: a de ter apanhado e comido dois veados mateiros. O curioso aqui, porém, é que a motivação para a caça ou a mentira, para um novo episódio no livro enfim, deriva simplesmente de um provérbio. E assim o enredo vai progredindo - ou se atrasando -, recheando-se de contos que competem entre si em matéria de gostosura. De modo que, quando terminamos de ler o episódio que supostamente viria no auge de uma acumulação dramática, a luta com o gigante, sentimos que o importante deslizou por entre nossos dedos, que comemos algo muito saboroso, mas mal o aproveitamos. $\mathrm{Na}$

Moraes, que fora proprietário de terras e governador de Goiás. Na tela A partida da monção, de Almeida Júnior, sua figura faz companhia à dos bandeirantes (cf. Gilda de Mello e Souza, "O avô presidente", Revista Discurso, n.11, São Paulo, 1980). Por que não dizer que Macunaíma é também um proprietário ou um bandeirante ou ainda um explorador exógeno, um viajante à busca do velocino de ouro, como diz na carta para as amazonas, que, aqui, pela construção paródica, nos remetem à Corte de Portugal? Enfim, Macunaíma, como Venceslau, é também extremamente plástico e se presta a muitas figurações, o que torna sua interpretação uma empresa arriscada, que conta com poucos elementos estáveis.

${ }^{70}$ Macunaíma, p. 94. 
verdade luta propriamente não foi, e sim uma seqüência relativamente rápida de ardis, deliciosos é seguro - mais do que estes, bastante tradicionais, semelhantes aos de fazer o gênio voltar para a lâmpada, é especialmente interessante a prosa em que são transcritos. Não que não seja um momento muito bom no livro, arrematado de maneira melhor ainda (com o "falta queijo" e o monstro de novo imergindo nas profundas do seu sangue de tomate). $O$ fato é que não conseguimos mais distinguir a qualidade exata de sua composição em meio a tantas outras iguarias, uma das quais a narrativa, longa e algo entediante, que imediatamente precede a luta, a da onça palauá. Às vezes sentimos um certo enjôo, às vezes muito (como no conto sobre o Pai do Mutum ${ }^{71}$ ), mas logo nosso paladar volta a ser atiçado e assim vamos. Se realmente pudermos sentir a desierarquização flagrante entre os episódios, deliberada da parte do escritor, que reproduziu uma técnica do populário, concluiremos que a Carta é muito menos apendicular do que se imagina e não é necessário, para entender sua inserção, recorrer a intenções alegorizantes ${ }^{72}$.

\footnotetext{
${ }^{71}$ Macunaíma, pp. 91-92

72 “O que caracteriza mais o aspecto contemporâneo de todas as nossas danças dramáticas, é que elas, como espírito e forma, não são um todo unitário em que desenvolve-se uma idéia, um tema só. O tamanho delas, bem como o seu significado ideológico, independe do assunto básico. No geral o assunto dá ensejo a um episódio só, rápido, dramaticamente conciso. E esse núcleo básico é então recheado de temas apostos a ele: romances e outras quaisquer peças tradicionais e mesmo de uso anual se grudam nele; textos e mesmo outros núcleos de outras danças se ajuntam a ele. Às vezes mesmo estas aposições não têm ligação nenhuma com o núcleo [...]. Esse processo de construir por aposição discricionária, culmina na forma atual de certas versões principalmente pernambucanas do Bumba-meu-Boi em que a coincidência com a revista do teatro praceano é flagrante. O episódio que foi nuclear um dia, não tem agora importância maior que os episódios acessórios, e apenas figura no fim ainda salientando o boi, não mais pelo drama, porém pela apoteose" (Mário de Andrade, apud Gilda de Mello e Souza, op. cit., pp. 14-15). Essa técnica, o Autor tinha em vista claro, era praticada pela vanguarda artística.
} 
Voltando à questão da colagem: mesmo emoções muito triviais, que recebem uma expressão correspondentemente primária, como "teve ódio", "sentiu que ia chorar", "jurou vingança", "se lembrou de matar o gigante", se mostram, pela repetição constante e por uma abotoadura meio torta na narrativa, pois normalmente aparecem do nada, frases feitas, que em geral atuam como pontos de ligamento entre as aventuras. Portanto são também material reaproveitado. Ou assim devemos sentir que seja - isto é, se não são ready-made, tomam deste a feição. Verdade é que, no embalo da prosa extraordinariamente unificadora, o construído se iguala ao jápronto, o personagem inventado pelo autor subsiste no mesmo registro que a figura mitológica, assim como a esta se assemelha em semblante, linguagem e existência toda personalidade histórica, Zumbi ou Domingos Jorge Velho, João Ramalho ou Bartolomeu de Gusmão; por seu turno, o elemento publicitário, como uma marca de inseticida que se torna verbo (flitar), passa por folclórico, e a máquina é no fim das contas natureza. No que diz respeito à imitação do ready-made, a própria obra cria um sistema de circulação em que é possível contemplar como o elemento construído - uma sensação, tique, interjeição, frase, gesto, ato heróico, pancadaria, sentimento, fuga, viagem, sonho, estima por legornes, arranco de genialidade, sortilégio -, por força de ser repetido ou encadeado aos elementos preexistentes, adquire o aspecto destes, sendo todos mergulhados na mesma água conformadora. Mas a que deve a plasticidade dessa estrutura?

Para responder a essa questão, é preciso ter em vista que, na relação do Autor com o material já disponível e de múltipla procedência, Gilda de Mello e Souza destacou três condutas: 1) extração de trechos do populário, pouco modificados na estrutura em que eram reacomodados; 2) dissolução de frases populares no tecido da prosa; 3) e, por último, não propriamente a transposição de documentos anteriores, 
mas de "normas de compor, constâncias sintáxicas, motivos rítmicos, maneiras tradicionais de cadenciar a frase, (...) processos 'já perfeitamente anônimos e autóctones, às vezes peculiares e sempre característicos do Brasileiro'(...)"73. Este terceiro membro encerra operações decisivas para o que chamamos de mimese da imitação. Por ora, entendamos que com "normas de compor" a autora esteja aludindo à tese de que a estrutura da obra teve por inspiração sobretudo as formas da variação e da suíte, ou, para tomar a cada qual um gênero em que se realizam, o improviso do cantador nordestino e a canção de roda. Esta, por seu turno, teria infundido a Mário pelo menos quatro modos de operar: 1) a reunião, numa mesma seqüência, de textos muito diversos, 2) a projeção de um sentido recente num texto inalterado, 3) a conservação do entrecho original com a modificação de todos os detalhes e 4) a invenção de uma nova seqüência a partir da fusão de dois documentos, com a troca dos personagens de um pelos de outro "e, assim, indefinidamente" ${ }^{, 74}$.

Digamos que o terceiro item do índice de procedimentos com o material prévio, item que inclui, como foi visto, constâncias sintáxicas, maneiras tradicionais de cadenciar a frase, motivos rítmicos, normas de compor - e portanto todo o conjunto de possibilidades sugeridas, em nível erudito e popular, pela forma suíte e pela variação, conforme o exposto sobre esta páginas atrás - é o campo que fornece os meios para a imitação da imitação, no caso, imitação da imitação popular. A cada uma das partes enumeradas Gilda de Mello e Souza, apoiada no Ensaio sobre a música brasileira, fez corresponder uma etapa do nacionalismo musical. Assim é

\footnotetext{
${ }^{73}$ O tupi e o alaúde, p. 26.

${ }^{74}$ O tupi e o alaúde, p. 26. Cf. tb., a propósito, "Influência portuguesa nas rodas infantis do Brasil", in Música, doce música.
} 
que a migração para a obra de textos quase inalterados se liga ao que fizeram compositores no início da prática nacionalista, como Luciano Gallet; a dissolução de motivos folclóricos numa nova estrutura remete à música de Lorenzo Fernandez, em momento mais avançado do modernismo nacionalista. A terceira era bem o caso dos compositores da última fase ${ }^{75}$. Repare-se como ocorre de seção a seção um decréscimo da imediatez no uso do repertório popular e um aprofundamento da reflexão sobre ele, que, no grau mais adiantado, já não está em presença, e sim em abstrato (sintaxes, cadências, ritmos, modos de compor). O livro conteria as três etapas, que se associam a todo momento, vivas e laboriosas; mas é sem dúvida a última que lhe fora mais produtiva, pelo horizonte que abre de combinações, deformações e metamorfoses, estimuladas por uma morfologia excepcionalmente bem reconstruída e por uma língua veloz em processar e pôr em presença uns dos outros vários níveis históricos do português no Brasil ${ }^{76}$. Tudo nela parece tomar a mesma e intrigante feição, como no pélago os destroços de um navio e as criaturas marinhas. Quem os contempla sabe que são coisas de natureza e história distintas, mas também diria que parecem envoltos por uma película, no interior da qual convivem em paz, entram uns pelos outros, com indiferença recíproca sobre sua constituição. É essa membrana a própria substância conformadora do mesmo e do diferente, do tradicional e do individualizado, do modificado e do inédito, do datado e do atual, do histórico e do mitológico, do proverbial e do propagandístico, do London Bank e da caapora, de São Paulo e do Brasil.

\footnotetext{
${ }^{75}$ O tupi e o alaúde, p. 26.

${ }^{76}$ Não sei dizer se os compositores da última fase, como Villa-Lobos, chegaram no seu âmbito a uma solução do nível de Macunaíma.
} 
II

(...) Assim nasceu uma poesia nacional que, levantando as tarifas de importação, criou uma indústria brasileira.

(João Ribeiro comentando Oswald de Andrade)

Riquezas naturais

Muitos metaes pepino romans e figos

De muitas castas

Cidras limões e laranjas

Uma infinidade

Muitas cannas daçucre

Infinito algodam

Também há muito paobrasil

Nestas capitanias

A roça

Os cem negros da fazenda

comiam feijão e angu

Abóbora chicória e cambuquira 
Pegavam uma roda de carro

Nos braços

Transação

O fazendeiro criara filhos

Escravos escravas

Nos terreiros de pitangas e jabuticabas

Mas um dia trocou

O ouro da carne preta e musculosa

As gabirobas e os coqueiros

Os monjolos e os bois

Por terras imaginárias

Onde nasceria a lavoura verde do café

Estes poemas pertencem a diferentes seções de Pau-Brasil, de Oswald de Andrade. O segundo deles, tomado a "Poemas da Colonização", tem na linha central o momento mais alegre: "Abóbora chicória e cambuquira". Não por se tratar de hortaliça, um termo brota de outro de maneira natural, quase irresistível, o que se deve à ordem em que aparecem. Esta obriga a uma leitura veloz. Na verdade, a agilidade é o aproveitamento do resíduo de força despendida para vencer uma resistência inicial. É que não é fácil sustentar o segundo bo de abóbora, mera repetição, embora de caráter átono, o que mais realça sua natureza derivada. Essa duplicata é ainda por cima seguida de uma vibrante simples, de prolação especialmente sutil se vem depois de um som explosivo, como é o caso. Podemos usar um ardil para enfrentar tamanha sofisticação articulatória, que exigiria uma 
emissão mais lenta e cuidadosa; podemos fazer com o destonificado bo e o melindroso $r a$ um colchãozinho que amorteça um pouco o salto do trampolim bó. De fato, abobra é freqüente como pronúncia não erudita, e tendemos a reproduzi-la aqui -se não ao menos abóbura, com o $u$ brevíssimo, mais que semivocalizado embalados pela omissão de pausa entre o primeiro e o segundo elemento da série e por sua cadência animada. A energia que se liberou para superar a dificuldade de pronunciar o primeiro termo transmite-se aos demais, e isso é tanto mais estimulado ante o fato de que fazem aliteração em $r$, de que se trata de uma tradicional seqüência trimembre, de que as palavras estão dispostas de maneira a determinar bem o ritmo (jambo-anapesto-jambo), jamais afrouxado. Seria um trava-língua não tivesse sido logo dissolvido o entrave, como enfatizei, não houvesse entre as aliterações espaço-tempo suficiente para não serem emboladas. $\mathrm{O}$ trava-língua propõe justamente o desafio de manter, a qualquer custo e a qualquer velocidade, a integridade prosódica de palavras que, juntas, parecem zombar de tal finalidade. No caso em questão, a deformação de início infligida é o disparo de que precisamos para correr jovialmente com a leitura, cujo andamento, porém, volta a diminuir adiante.

A linha central forma o clímax do poema, no qual a pequena lista culinária, iniciada antes (“comiam feijão e angu”) e a propósito da alimentação na senzala, se enriquece e espessa e por fim se destaca do quadro de roça que ajuda a descrever. Da sonoridade monotonamente anasalada e fechada de "feijão e angu", que designam aliás vulgares mas vitais enche-barrigas, passa-se a um arranjo colorido de timbres e a uma alternação mais regulada de sons fracos e fortes, responsável por um ritmo de qualidade diversa daquele que abre a composição. Quanto à altura, o $a$ ora está no meio, ora desce um pouco, ora alcança uma posição 
melhor na hierarquia, mas se incumbe servilmente de guardar a fila nos dois lados; há duas tônicas consecutivas em $o$ aberto, e a terceira, se cai no $i$, é porque já fora anunciada pela pretônica e pela semivogal do ditongo crescente em que terminava o termo anterior (chicória). Este tem a sequiência final de sons consoantes amavelmente reiterada pelo último vocábulo (córialquira), o qual retoma também como um ator por natureza simpático à convenção de chamar da coxia os colegas que o precederam na peça - o fonema que começava toda a brincadeira $(\mathbf{a b o ́} / c a m b u)$. Provavelmente a melhor parte da comida para quem trabalhava tão pesado não fosse o frugal mato de abóboras e grelos, mas a verdade é que é ao ler seus termos designativos tal como estão organizados que sentimos um verdadeiro divertimento, como se pudéssemos ferrar o pé com gosto no acelerador do carro que vai por uma estrada vazia e ensolarada. A linha seguinte exige que retomemos o passo mais moderado que caracterizava o início do texto. Reproduzida a força de trabalho com carboidrato e legume, vem o trabalho propriamente: "Pegavam uma roda de carro /Nos braços". O retardamento é maior ainda na virada de um verso para outro, sendo este concluído numa longa fermata. A desaceleração súbita, em comparação com a desenvoltura folgazã que se atingira, corresponde à retomada do compromisso com a cena de colonização. E aqui isso é cancelar o brinquedo. $\mathrm{O}$ todo é uma cena apagada, embora com um incisivo risco de cor. Tanto é que o reconhecimento da proeza quase hercúlea, não importa se inata ou na marra, que está em levantar uma roda de carro - de boi, supõe-se - não nos impressiona como nos tinha deliciado a trinca cintilante de imagens, que, conquanto fossem muito triviais, estavam acrescidas, graças a sua combinação, aos meios técnicos assinalados, de um encanto especial. Excediam a realidade a que se referiam, como acontece com as senhas mágicas. Assim, quando se volta aos peões, o melhor já 
passou. E isso ocorre num ciclo em boa parte feito de casos de polícia e assombração que a cultura de trabalho compulsório produziu largamente. Note-se que, das 15 peças em que consistem os "Poemas da Colonização", são apenas cinco os que não tratam diretamente da vida dos cativos, embora os suponham ou mesmo os mencionem de passagem ${ }^{77}$. Dos demais 10, apenas dois, "o gramático" e "a roça", que estamos analisando, não trazem exatamente um caso de violência contra escravos, de revolta da parte destes ("Contam que houve uma porção de enforcados"78), ou mesmo assassinato, por ressentimento decerto, como o que moveu Ambrósio, "que atacou seu Juca de faca"79. Porém, mesmo em "o gramático", segundo o qual os negros discutiam "que o cavalo sipantou" e "o que mais sabia" observou que era "sipantarrou", podemos nos perguntar, já que a conversa veio a ser interrompida por uma questão morfológica, interrupção que é o conteúdo aparente do poema, o que afinal teria espantado ao cavalo. Talvez uma das almas do trabalho forçado de que se suspeita não acharem descanso nem com a morte, como a da mulatinha que morreu "E apareceu/Berrando no moinho/Socando pilão" ${ }^{80}$.

Voltando a "roça", se não pinta corpos espedaçados, enforcamentos, afogamentos, facadas, estupros e o diabo, não deixa de indicar, laconicamente quanto às palavras mas cheio de alusão no andamento muito ralentado do fim, parte da penosa rotina fixada para os escravos. E o faz de uma perspectiva da qual estes

\footnotetext{
${ }^{77}$ São eles "relicário", "senhor feudal”, “a transação”, “o recruta”, "o medroso”. Este, bem como o "fantasma" que o aterroriza, pode ser um escravo. Nesse caso, entraria na outra série, que viria a somar 11 poemas, e não 10 .

78 "levante".

79 "fazenda antiga".

80 "caso".
} 
parecem antes uma velha raça de seres fabulosos, dotados de força sobre-humana ou infernal para carregar no braço objetos tão pesados e grandes. De modo que essa sobrenaturalidade, se tem o efeito de os distanciar um tanto de nós, induz a perguntar sobre seu enigma: sobrenaturalidade ou sobretrabalho, o qual consumia um braço em sete, oito anos? Também deles diria Marx: “(...) são homens comuns e não ciclopes" ${ }^{\prime 81}$. O sujeito do poema conta como se não lhe tivesse ocorrido fazer tal distinção, ou passa a história tal como a ouviu, preservando a bruma em que não se decide se os negros são seres demoníacos ou a avidez dos senhores não tem limites. Essa bruma não está apenas no texto, mas andou anuviando a cabeça de muita gente, sobretudo após a Abolição. Nessas questões, me parecem, nos fazem refletir as duas últimas linhas de "a roça". E é sempre prazeroso poder refletir assim. Mas penso que o "princípio de prazer", o princípio de "não adiamento do prazer", está concentrado mesmo em "Abóbora chicória e cambuquira". Devemos nos perguntar, no entanto, por que essas enumerações, que facilmente adquirem um caráter digressivo e nos desencaminham também, vêm a ser tão do gosto de Macunaíma e Pau-Brasil - para tomar só dois exemplos fortes, não por acaso pertencentes aos dois maiores escritores do Modernismo de vinte, isto é, que produziram grandes obras já nesse período.

Em relação ao poema de Oswald, lembramos que é um dos poucos da divisão à qual pertence que fazem uso da enumeração, ao contrário de todas as demais do livro e do poema-programa que o apresenta ${ }^{82}$. Veja-se a primeira parte de Pau-Brasil, intitulada justamente "História do Brasil", a que a primeira composição

\footnotetext{
81 “A jornada de trabalho”, O Capital, vol I. São Paulo, Abril Cultural, 1985, p.203,

${ }^{82}$ Poema que é a redução do "Manifesto da Poesia Pau-Brasil", publicado no Correio da Manhã, Rio de Janeiro, 18/3/1924. Ver Poesias reunidas, pp.76-77.
} 
destacada acima, "riquezas naturais", com português quinhentista e tudo, está incorporada. Nesse segmento, fornido da literatura de viajantes, a enumeração é um processo que naturalmente prevalece. João Ribeiro, em artigo de 1927, observou que, com seu primeiro livro de poemas, Oswald de Andrade inaugurara um estilo conforme o qual o folclore e os cronistas passavam a ser escutados como oráculos emudecidos $^{83}$. O que esses oráculos voltaram a dizer? O jargão dos escravos, nomes de antigos objetos de uso e de trabalho, personagens, instrumentos de tortura, incontáveis nomes de plantas e animais, acidentes geográficos, metais preciosos, semipreciosos (a Antropofagia traria mais carregamentos, de objetos do cotidiano e de mitologias indígenas) etc. Basicamente substantivos concretos, comuns ou próprios. O estudo da história do Brasil resultou em sortimento do léxico, numa ampliação produtiva do vocabulário; o espírito taxionômico do século 17, que influenciaria tanto a literatura de viagem subseqüente e o Iluminismo francês, é retomado não apenas em chave paródica. Ele dá impulso ao novo espírito classificatório que o Modernismo, no rasto do nosso Romantismo e, em condições bastante específicas (ou melhor, em outro nível de desenvolvimento das forças produtivas materiais), adensaria ao máximo. Assim, Pau-Brasil não é apenas a visita a um museu com direito a suvenires e miniaturas como também a um mercado atualizado, em cujo frontispício, porém, está a placa desde 1500. Com algumas reformas e ampliações, tudo pôde caber aqui. Os substantivos estão sobrecarregados de função - devem encher a loja, exibir tudo o que temos. Manuel Bandeira viu bem quando, a propósito de Macunaíma, disse: "Você empregou otimamente o processo rabelaiseano das enumerações verbais gostosíssimas em se tratando de frutas,

\footnotetext{
${ }^{83}$ Apud Haroldo de Campos, "Uma poética da radicalidade", in Oswald de Andrade, Poesias reunidas, Rio de Janeiro, Civilização Brasileira, 1978, p. 47.
} 
árvores e bichos do Brasil, é realmente o único meio de abranger toda a gostosura que vai por aqui" 84

${ }^{84}$ Correspondência Mário de Andrade \& Manuel Bandeira. Org. Marcos Antonio de Moraes. São Paulo, Edusp/IEB, 2000, p.358. 
III

\author{
“À primeira vista, a riqueza \\ burguesa aparece como uma \\ imensa coleção de mercadorias..." \\ (Marx) \\ “...cujo nome pode ser o de um \\ país, vegetal ou mercadoria..." \\ (Octavio Ianni)
}

Entre os "processos individualistas do folclore" utilizados no romance, é a enumeração que salta à vista menos desarmada. Arrisca-se a ficar sem chão quem a ignorar e for "ao que interessa". No pequeno trecho do capítulo "Vei" analisado na primeira parte deste estudo vimos como em certo momento a tendência classificatória, evidenciada nas designação de espécies exóticas, era travestida por recursos como diminutivos, qualificadores, artigos. Estaríamos diante de um narrador rústico, que, durante seu relato, dá a ver muito instintivamente um minucioso conhecimento da natureza, de fonte popular, indígena e vez por outra científica, esta adquirida quem sabe num almanaque, na conversa com um sábio viajante de passagem etc. Não é exatamente assim que se passam as coisas. Antes mesmo de toparmos com -uma palmeirinha guairô, muito aromada, uma enxurrada de frutas já tinha sido despejada: "sapotas sapotilhas sapotis bacuris abricôs mucujás 
miritis guabijus melancias ariticuns, todas essas frutas" ${ }^{\prime 85}$. Claro que o exotismo do nome dependerá da região de que se origina o leitor. De minha parte, conheço apenas a melancia e o abricô, ou abricó, um tipo de damasco, e ouvi falar do sapoti. Dos demais, dois se reduzem ao sapoti: sapota é, conforme o Aurélio, a parte que contém propriamente o bago, e sapotilha, no glossário de Cavalcanti Proença, é uma mera variante. $\mathrm{O}$ miriti, para ser mais preciso, indica antes a palmeira que o fruto dela. Vê-se por aí que as palavras estão sobrando para as coisas ou nem sempre são exatas. Sua disposição, contudo, foi criteriosa: realçou ritmo, grupos de aliteração, assonâncias seguidas (sapotilhas sapotis bacuris) ou interpoladas (como em miritis guabijus x melancias ariticuns). Já se explicou a falta de vírgula nas enumerações do livro por influência das listas nas emboladas. E, indo pelo mesmo rumo, se pode atribuí-la à falta de mensuralismo rítmico na música popular, a que Mário deu especial relevo em diversas ocasiões. Chamava-lhe de ritmo prosódico, ou recitativo $^{86}$, livre das injunções do compasso e variável conforme a improvisação do músico. Mas o procedimento também remete à poesia moderna. Adorno, por

\footnotetext{
${ }^{85}$ Macunaíma, p. 65.

${ }^{86}$ Veja-se, no Ensaio sobre a música brasileira, a seção sobre o ritmo.. “(...) muito pouco pianista no Brasil conhece rítmica brasileira. A gente aqui vive mergulhado na rítmica pobre e batidinha da música tonal européia. Quando topa com a desarticulação sistemática do compasso da música brasileira e norteamericana, com os acentos desorganizadores do preconceito clássico do compasso, com a síncopa variada, fica desnorteado e não consegue realizar direito o acompanhamento" ("Luciano Gallet", in Música, doce música, p. 166). O "preconceito clássico do compasso" é discutido em vários artigos. Em "Dinamogenias políticas” (Música, doce música), explica-se: "Em música, o recitativo é justamente o processo em que o eterno desequilíbrio entre o movimento discursivo dos textos e a rítmica artificial do Mensuralismo, é quase que totalmente destruído" (p. 99). Sobre as melodias "livres de ritmo certo" em Chico Antônio, cf. Vida de cantador, p. 63. Weber diria que o referido preconceito fez parte do inevitável processo de racionalização da música ocidental, sem o que não se teria liberado seu desenvolvimento.
} 
exemplo, julga que fora inútil a omissão dos sinais de pontuação praticada pela escola de Stefan George [não apenas por ela, na verdade]. É útil usá-los e vão escondê-los, diz, pois o texto os repõe por si mesmo ${ }^{87}$. Trata-se de um argumento muito bom, razão por que não convence a explicação segundo a qual Mário subtraiu a vírgula para influenciar na velocidade com que devia ser feita a leitura, ou a suposta narração oral ${ }^{88}$. Tendemos a ler naturalmente mais rápido uma enumeração, e a vírgula nesse caso não teria função prosódica, isto é, não corresponderia a pausa na fala, mas seria um marco racional da justaposição de elementos com natureza morfossintática semelhante. Com ou sem ela, a dinâmica, um allegro vivace, praticamente não se altera. Mas é preciso discordar de Adorno num aspecto: ainda que o tráfego interno à linguagem seja restabelecido, e a pontuação se torne "presença incorpórea", não esquecemos o que o olho registrou, a imagem gráfica, conforme a conceituação de Saussure, da falta de vírgula, que pode não ser tão perfunctória assim. Se continuamos a ler da mesma maneira, ou se as ruas do texto nos forçam a levar em conta sua sinalização tácita, somos atingidos pela retirada dos sinais ostensivos, pela imagem dessa retirada. A coisa se passa como se tivesse sido removida a baia que ordenava as palavras, e estas agora recusassem o atendimento em série, não se inibindo mais em concorrer entre si para ter toda a nossa atenção. Estão de tal modo soltas dos lados que parecem se desprender até da linha da página, ameaçando subir um pouco. Ou foi a percepção que se tornou astigmática, e são antes as linhas que flutuam com a falta de vírgulas, os pequenos ganchos que as

\footnotetext{
${ }^{87}$ Adorno, "Sinais de pontuação", Notas de literatura I (trad. Jorge de Almeida), São Paulo, Duas Cidades/Editora 34, 2003, p. 142.

${ }^{88}$ O próprio Mário de Andrade diz na carta a Raimundo Moraes que utilizou "processos de pontuação oral" (Macunaíma, p. 487).
} 
prendiam e lhes confirmavam a horizontalidade. De agora em diante talvez esta entre em crise, a pauta se desmanche, as palavras levitem e até mesmo se abracem num círculo, como pôde acontecer com inscrições em cúpulas de igreja e em alguns momentos da história literária, p.ex. na poesia barroca. Estamos longe disso aqui, mas estou chamando a atenção para um aspecto em que Mário de Andrade parece investir: a tangibilidade dos signos.

Retomando um artigo de Detlev Schumann sobre o "estilo enumerativo" na poesia moderna, Leo Spitzer observa: "todo traço de estilo é em si mesmo neutro: adquire sua eficácia particular apenas por seu enlace com tal ou qual atitude particular. Dentro do arquivo chamado 'estilo enumerativo', há grande número de compartimentos: os dos três autores estudados por Schumann... e muitos outros" ${ }^{\text {" }}$. A esses autores, ou seja, Whitman, Werfel e Rilke, o ensaísta ajunta, entre outros: Darío, Neruda, Salinas, Jules Romains - e os unanimistas de um modo geral -, Claudel.., procurando lhes especificar a mesma técnica. Já Schumann teria apontado diferenças quanto ao sentido produzido no uso da enumeração pelos poetas analisados, todos curiosamente, mas não do mesmo modo, "panteístas". Restava, porém, identificar com mais exatidão o elemento que revelava a modernidade do procedimento, pois

No que Schumann chama globalmente "estilo enumerativo" se fundem diversos elementos de época e procedência histórica distintas: a enumeração, velha como o mundo; a anáfora (em Werfel

89 "La enumeración caótica en la poesía moderna" (trad. Raimundo Lida), Lingüistica e historia literaria, Madri, Editorial Gredos, 1955, p. 300. 
e Claudel), procedimento de fisionomia particularmente medieval; o assíndeto, conhecido na Antigüidade e ressuscitado pelo Renascimento, e, finalmente, o que em meu artigo sobre Salinas chamei de "enumeração caótica". O caotismo é sem dúvida a nota moderna que Schumann não definiu com bastante clareza, ainda que empregue o nome de "enumeração heterogênea". Parece, com efeito, que é a Whitman a quem devemos esses catálogos do mundo moderno, desfeito em uma roda-viva de coisas heterogêneas, que se integram, não obstante, em sua visão grandiosa e majestosa do Todo. Nem Rilke, nem Werfel, nem Claudel conhecem o vigoroso assíndeto de Whitman (e, em grau menor, de Rubén Darío), que aproxima violentamente as coisas mais díspares, o mais exótico e o mais familiar, o gigantesco e o minúsculo, a natureza e os produtos da civilização humana, como uma criança que estivesse folheando o catálogo de uma grande loja e anotando em desordem os artigos que o acaso pusessem sob sua vista; mas uma criança que, sendo também sábia e poeta, extraísse poesia e pensamento de uma lista de áridas palavras; uma criança genial como Victor Hugo $^{90}$ (grifos meus).

A enumeração, "velha como o mundo", a anáfora, o assíndeto e a enumeração caótica se mesclariam na lírica moderna; contudo é a última, desenvolvida pelo poeta norte-americano, o processo realmente novo, no qual, ainda assim, o autor reconhece tanto a tradição das litanias cristãs como o fragmentarismo do barroco espanhol, fragmentarismo ao qual não se impõe mais nenhum freio de ordem, como em Quevedo ou Calderón ${ }^{91}$. Em nota ao trecho reproduzido, é esclarecido: "Não há anacronismo nisso de referir as enumerações de Whitman - o

\footnotetext{
${ }^{90}$ Leo Spitzer, op. cit., pp. 307-308.

${ }^{91}$ Leo Spitzer, p. 344. Quanto especificamente à enumeração na tradição cristã, v. pp. 311-317. Para a análise do assíndeto na poesia barroca espanhola e da supressão latinizante do artigo indefinido, praticado também por Whitman, v. pp. 317-329.
} 
'poeta do catálogo' (Katalogdichter), segundo a expressão de Eulenberg - aos grandes armazéns de artigos vários. Até 1855, ou seja, na data de publicação de Leaves of grass, é quando começa o enorme desenvolvimento desses bazares ocidentais, os department stores, produzido pela acumulação de riqueza e pela extensão do comércio e dos meios de transporte" ${ }^{, 92}$. Não obstante se adverte, página adiante, que o "estilo bazar" já fora inventado na Europa: "Em Balzac, esse procedimento continua espontaneamente a enumeração de Rabelais, a quem o célebre romancista imitou tão amiúde em sua juventude" ${ }^{\text {993 }}$. E cita-se uma extensa passagem inventariante de Croquis et fantaisies, de 1830, a qual reproduzo para mais tarde recuperar a propósito das enumerações em Macunaíma:

C'était une maison singulière, un panorama, une vraie galerie physionomique, un bazar de figures, de fortunes et d'opinions. Femmes charmantes, femmes savantes, femmes innocentes, femmes prudes, femmes parvenues, femmes coquettes, auteurs, acteurs, orateurs, prosateurs, poètes, magistrats, avocats, diplomates, académiciens, agents de change, gallicans, ultramontains, républicains, monarchistes, papistes, bonapartistes, cartistes, orléanistes, anarchistes, alarmistes, nouvellistes, feuillistes, libellistes, publicistes, journalistes, artistes s'y coudoient, s'y choient, s'y rudoient [etc. ${ }^{94}$.

A retomada da lista rabelaisiana, "com seus agrupamentos por sufixos ou famílias de idéias", com efeito muitas vezes satírico, talvez tivesse sido inspirada ao autor da Comédie humaine também pelo comércio contemporâneo: "Recordemos

\footnotetext{
${ }^{92} I d$., p. 308n.

${ }^{93}$ Id., p. 309.

${ }^{94}$ Apud Spitzer, p. 310.
} 
que o primeiro grand magasin de Paris, 'La Ville de Paris', na rua de Montmartre, abriu suas portas em 1834: a coincidência de datas é significativa. Balzac é o eco

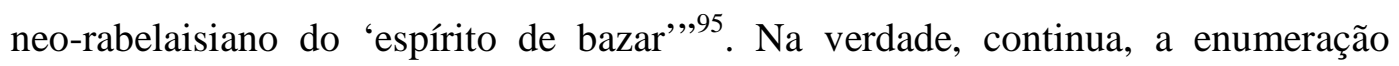
caótica seria um desdobramento da mescla estilística que Auerbach identificara no romance do século 19. Assim como se afrouxam os limites entre classes sociais e se reconhece a dimensão trágica do cotidiano do homem médio, de que é reflexo a desierarquização de estilos e gêneros literários, também se associam as coisas mais supostamente díspares quanto à graduação. À “democracia humana”, que obrigou à mescla estilística, sucederia naturalmente a "democracia das coisas" ${ }^{\text {: }}$ os objetos mais vulgares da civilização industrial têm assento junto de elementos da natureza, sentimentos, tradicionais símiles e topoi, nobres pensamentos. O fungível e o não fungível se enlaçam, como técnica e natureza - entre magnólias e telegramas, diz um verso de Neruda ${ }^{97}$ - uma associação que hoje virou moeda corrente. A uma tal "democracia das coisas" também se dobra a narrativa. Franco Moretti parece concordar com Spitzer e, retomando a teoria de Auerbach, acrescenta a observação de desde fins do século 18 o romance europeu foi progressivamente se desencantando (no sentido weberiano do termo) do inaudito, do acontecimento inesperado. O pano de fundo da cinzenta rotina, por séculos recatadamente descrita e contra a qual o romanesco adquiriu relevo, passa a receber todas as honras, tal como Vermeer já lhe concedera na pintura ${ }^{98}$. Narrar ou descrever?, pergunta um subtítulo no ensaio de Moretti. A resposta é evidentemente descrever. A descrição, diz, é o

\footnotetext{
${ }^{95}$ Spitzer, p. 310.

${ }^{96}$ Id., p. 343.

${ }^{97}$ Apud Spitzer, p. 340.

98 "O século sério - o romance europeu do Oitocentos" (trad. de Alípio Correa e Sandra Correa), Novos Estudos CEBRAP, São Paulo, março de 2003, n. 65 p. 15.
} 
modo como chega ao romance o processo de racionalização na modernidade investigado por Weber nos mais diversos domínios" 99 . Sendo o realismo “imitação séria do cotidiano", do cotidiano burguês especificamente, conforme a definição que está em Mimesis, era natural que as narrativas se detivessem nos incontáveis objetos, hábitos e pequeninos fatos que urdem a sucessão dos dias: "Uma verdadeira 'descoberta' do cotidiano opera-se no romance da primeira parte do século XIX: a trama se adensa, enche-se de mil coisas (como quase tudo na época: as nações se enchem de estradas e depois de ferrovias; as cidades, de casas; estas, de móveis; os móveis, de infinitos objetos...)"100. Spitzer, porém, chegando ao século 20, acompanha o processo em que se passa dos infinitos objetos a seu merchandising: “(...) o torvelinho de palavras, de slogans, de frases feitas, se acrescentará nos romances de Joyce e Döblin, aos torvelinhos de coisas que se agitam em torno do homem moderno, e pode tornar-se mais 'real', mais obsessivo que a realidade mesma das coisas" ${ }^{, 101}$. Lukács também faria essa linha de sucessão, mas a tomaria a partir de Flaubert, ou a partir da literatura após 1848, isto é, após a brutal repressão exercida pela burguesia francesa às classes populares - as coisas se desvinculam do destino humano, e o narrador impassível é o intelectual que fora obrigado a se resignar com o rumo da política (com a Realpolitik). Isso culminaria na "revolução copernicana" que Proust, tomando emprestada a metáfora outrora aplicada a Kant, reconheceu no modo de representação do mundo inaugurado pelo autor da Educação sentimental: "Nas [suas] grandes frases as coisas existem não como o

\footnotetext{
99 Cf. as seções "Racionalização" e "O princípio de realidade", pp. 15-16 e pp. 19-21, respectivamente.

${ }^{100}$ Op. cit., p.13.

${ }^{101}$ Spitzer, p. 343.
} 
acessório de uma história, mas dentro da realidade da aparição delas; são geralmente o sujeito da frase, pois a personagem não intervém nem surpreende a visão: 'Uma vila surgiu, os choupos alinharam-se etc.",102 (grifos meus). Trata-se de uma revolução gramatical: "sua originalidade imensa, durável, quase irreconhecível, já que está de tal forma encarnada na língua literária de nosso tempo, a ponto de lermos Flaubert sob o nome de outros escritores sem saber que eles não fazem outra coisa senão falar como ele, é uma originalidade gramatical"103. A sintaxe torna visível que se alterou o ponto de conhecimento e observação, no qual Proust também está situado, mesmo com seu narrador em primeira pessoa. Na cena do passado redivivo pela memória involuntária, o qual pode estar fetichistamente encerrado num objeto material qualquer, as coisas também existem "dentro da realidade da aparição delas". Como escreveu Curtius: "Proust não reconhece a separação [cartesiana] entre substância pensante e substância extensa. Ele não divide o mundo em psíquico e em físico. O significado de sua obra é reduzido se a observamos da perspectiva de um 'romance psicológico","104. Todo o real, coisas e homens, está mergulhado num mesmo "fluido anímico" 105 . Se seu romance pretende ser a suma da experiência humana, falta-lhe paradoxalmente o elemento mais motivador da narrativa: o desejo - de ascensão, poder, dinheiro, amor, fama etc. ${ }^{106}$. O único desejo é de conhecimento. Repisando os termos: ser o mais possível fiel às coisas "na

\footnotetext{
${ }^{102}$ Contre Sainte-Beuve (trad. Haroldo Ramanzini). São Paulo, Iluminuras, 1988, pp. 136-137

${ }^{103} I d$., ib.

104 Ernst R. Curtius, "Marcel Proust", Französischer Geist im zwanzigsten Jahrhundert, Munique/Berna, Francke, 1952, p. 312, e apud T. Adorno, "Trying to understand Endgame", Notes to literature (trad. Shierry Nicholsen), Nova York, Columbia University, pp. 253-254.

${ }^{105}$ Curtius, p. 313.

${ }^{106}$ Curtius, pp. 314-316.
} 
realidade da aparição delas". Talvez não seja equivocado ver nessa fidelidade a antesala da montagem. Tomando a formulação que Szondi fez do problema: se a patologia do drama moderno é a impossibilidade do diálogo intersubjetivo, a patologia da narrativa é a montagem, o cancelamento do narrador épico: "a montagem é o produto industrial da épica" ${ }^{107}$. As coisas se narram a si mesmas e por fim se anunciam a si mesmas, como na publicidade, fenômenos que Döblin permite deslizar (com folga demais, eu diria) para suas páginas. Na Recherche... o narrador se ampliou ao máximo, muito às expensas do impressionismo, tomou o mundo dentro de si, auscultou correspondências entre fatos da cultura e da natureza, entre o humano e o não-humano. Situações de ordem muito distintas podem guardar entre si uma (ainda grata) semelhança ${ }^{108}$; todos os elementos da existência empírica podem

${ }^{107}$ Teoria do drama moderno (trad. Luiz Sérgio Repa). São Paulo, Cosac \& Naify, 2001, pp. 144145.

${ }^{108}$ Essa semelhança é funesta em Kafka, sintoma de que a individuação é precária (em Proust, a dissolução dos limites entre mundo físico e mundo psíquico é acompanhada com fascínio, fascínio por chegar aos vasos comunicantes entre esses mundos. Os exemplos são mais do que copiosos, mas veja-se a comparação, logo no início do quarto volume da Recherche, no flerte do Barão de Charlus com o alfaiate Jupien e um fenômeno botânico a que o narrador assiste momentos antes de surpreender o primeiro fato. A contemplação da orquídea precipitou a compreensão da natureza do olhar entre os personagens. Segundo Curtius, a multiplicação de metáforas nessa obra está a serviço da precisão, são o "resultado da busca de um descrição precisa" (op. cit., p. 302). De um conceito, portanto. A reação proustiana ao conhecimento de que a separação entre sujeito e objeto não seja algo indubitável difere muito do horror com que o expressionismo constata isso e mesmo dos arrepios que sobrevêm à identificação de parecenças nas obras de um Thomas Mann, parecenças que são em 99\% das vezes arautos da morte. Veja-se também, a propósito desse tema em Kafka e sobre o mitologema do duplo, o excepcional ensaio de Adorno que está em Prismas (trad. Augustin Wernet e Jorge de Almeida), São Paulo, Ática, 1998. De todo modo, a atmosfera em Proust já é pós-psicológica e, nesse ponto, ele seria continuado por Beckett. Cf., a esse respeito, a interpretação que Adorno faz de Fim de partida e seus "particulares desesperados", homens e objetos fora do fuso, na op. cit. 
liberar uma alma secreta: termômetro de mercúrio, telefone, classe social, rosto, obra de arte, elevador, torres de igreja, certa fileira de árvores... Mas estamos diante de um sujeito hiperinflado, disponível como uma tela, e não diante de sua explosão. Ele precede o irracionalismo dos objetos que vêm para o primeiro plano e revoluteiam-se caoticamente em torno das figuras humanas - para voltarmos à análise de Spitzer. Este, Moretti, Lukács - e por certo outros que ou não conheço ou não recordo - estão dizendo algo parecido e muito simples num certo ponto, embora lhe dêem ênfase, juízo e desdobramento diferenciados: a literatura moderna, como as casas e os móveis, se acumulam de mercadorias. Spitzer não tira muitas conseqüências disso, pois sua preocupação é antes mostrar como um procedimento estilístico, especialmente se se enraíza em formas do culto religioso, e esse é o caso da enumeração, atravessa os séculos, serve a atitudes variadas e até conflitantes entre si, sempre dentro do que considera a "[eterna] luta entre o princípio de ordem e o princípio da autonomia" ${ }^{109}$. A enumeração pôde exprimir a inefabilidade do Deus monoteísta - é amplo seu inventário de nomes justamente porque nenhum o apreende - como pôde, no caso de Whitman, compelir todas os objetos do mundo: "Chamar a Deus Uno por meio de todos esses nomes inumeráveis, para que não possa evitar nossa invocação, é em suma um procedimento mágico, e esta magia da apropriação das coisas Walt Whitman transportou para as coisas mesmas, consideradas divinas em seu conjunto. (...) no fundo, toda a sua poesia enumerativa consiste em vocativos conjuradores de mago" ${ }^{110}$. Num dos apêndices a seu artigo, o autor expõe a teoria "surpreendente, mas convincente", defendida por um colega, de que o estilo enumerativo de Whitman se devesse a influência da literatura religiosa

\footnotetext{
${ }^{109}$ Spitzer, pp. 344-345.

${ }^{110} I d$, p. 314.
} 
indiana, a qual teria operado indiretamente, pelo intercurso com os transcendentalistas da Nova Inglaterra, como Emerson, a quem conheceu ${ }^{111}$. Menciono isso por duas razões. Mário de Andrade tinha em vista que essa técnica era comum tanto aos cantadores nordestinos, "nossos rapsodos atuais", como aos poetas de civilizações antigas como Índia, Egito e Grécia ${ }^{112}$. A enumeração consistia em ferramenta essencial a repentistas como Chico Antônio, à aos ensalmos de feitiçaria, ao Bhagavadgita, a Comodiano de Gaza ${ }^{113}$. O outro motivo, decorrente do primeiro, é que há algo daquela "magia da apropriação das coisas" nas enumerações em Macunaíma.

Como foi possível a Spitzer falar em bazar e magia, catálogo varejista e panteísmo a propósito de Whitman e de parte considerável da lírica moderna? Ele não explicita o que possibilita essa vinculação; na verdade, não é seu interesse. A brilhante percepção de que o caotismo na poesia norte-americana - e no romance balzaquiano - teria algum vínculo com os department stores não é fundamental para seu argumento, pois não é fundamental para seus pressupostos teóricos (na verdade, há uma contradição em seu texto: ele conclui pela continuidade estilística, acaba por explicar a violência do assíndeto moderno, que une os termos mais dessemelhantes, como um dos momentos da oscilação, na história literária, entre subordinação à tradição e autonomia, deixando na sombra, sem lhe dar maior alcance, aquela

\footnotetext{
${ }^{111} I d$, pp. 350-351.

112 Mário de Andrade, "Carta a Raimundo Moraes" (publicada no Diário nacional, São Paulo, 20/9/31), in Brasil: $1^{o}$ tempo modernista 1917-29, cit., p. 297; Macunaíma, p. 486.

${ }^{113}$ Apud Raimunda de Brito Batista, "O alcance da cantoria", in Vida do cantador, p. 27. Sem contar, evidentemente, o conhecimento que ele tinha do processo na poesia moderna e em especial nos unanimistas. Digo em especial porque Telê Porto ${ }^{a}$ Lopez investigou, em Mário de Andrade: ramais e caminho, a influência do unanimismo em sua obra.
} 
percepção, encerrada, é verdade, em nota de rodapé. Não obstante como pode a literatura, depois da inaudita produção material que o século 19 já exibia, para realçar bem o aspecto histórico-econômico levantado pelo próprio filólogo, continuar a oscilar entre pólos eternos?). Lukács, por seu turno, se horroriza com o fato de que as narrativas estivessem se tornando vitrines, exposições de objetos estaticamente desvinculados de destinos humanos. Espanta-se com que isso ocorresse até mesmo na Rússia revolucionada (poucos anos depois já riríamos com melancolia desse espanto e desse até mesmo) e os escritores não estivessem configurando o "novo indivíduo", mas, à exceção de alguns, reproduzindo processos decadentes da literatura burguesa, próprios ao naturalismo e à vanguarda, processos como a descrição fetichizante e antiépica, que tinham em Flaubert um antecessor de enorme talento, sincero em seus propósitos, mas... decadente, cético demais para formar uma visão clara do presente e uma perspectiva para o futuro, ou seja, para a ação - na política e, conseqüentemente, no romance (para Moretti, é também o peso do passado, da Restauração, que retira energia à mobilidade épica). Sob o sol do novo regime, constata Lukács, eram escritas obras em que os protagonistas eram fábricas e unidades de agricultura intensiva, e não homens.

Moretti fala em "desencantamento" e "racionalização". Mas há também uma contraparte de reencantamento, não mencionada nesse estudo, a qual afligiu Lukács, que já a identificara em Flaubert ${ }^{114}$ - como Proust o fizera, o que pode ser concluído

114 Essa aflição, que sem dúvida tem caráter normativo, não supõe, no entanto, uma estética sistemática, que reclamasse a continuação das formas através da história. Para a perspectiva evolucionista do autor de História e consciência de classe, o problema era que estava colocada em risco a transmissão ao proletariado das formas mais avançadas (antropomorfizadas) da cultura ocidental burguesa, e com ela, as possibilidades de representação do indivíduo pós-burguês. Os apelos de Lukács não prosperaram nem podiam prosperar. Contudo "Narrar ou descrever" não deixa 
pelo que ele entendia sobre a revolução gramatical nesse autor: esta não teria conformado uma espécie de "sujeito automático"? Talvez aquela contraparte fosse mais visível na violência do assíndeto de Whitman, que remetia aos catálogos do comércio contemporâneo e aos rituais de coação mágica. Entre estes, já pôde figurar o dicionário. Segundo Gordon Childe, "os dicionários sumérios serviram na medida do possível não apenas indiretamente, como dicionários para uma finalidade útil e necessária, mas também de maneira direta, como instituição em si mesmos, para dominar o que neles estava escrito; quanto mais completo fosse um tal catálogo, maior era a parte da natureza que se podia controlar através do conhecimento e da utilização desse catálogo" ${ }^{115}$. Em sentido que especificarei melhor, Macunaíma é um dicionário, um catálogo e uma instituição. Como vimos, Bandeira notou a Mário de Andrade que as listas no livro, de tipo rabelaisiano, se mostravam o modo mais adequado para abranger toda a "gostosura" das coisas brasileiras ${ }^{116}$. Essa ânsia inventariante deveria ser levada a sério, e não seria exato ver nessas relações de

de ser um texto valioso sobre os processos de desantropomorfização e abstração (a dissolução da unidade simbólica) em curso no romance.

115 Apud G. Lukács, "Probleme der Widerspiegelung im Alltagsleben", in Ästhetik I, Berlim, Luchterhand, 1963, p. 97.

116 Ver nota 80 neste texto. Roger Bastide também identificou a marca de Rabelais nas séries nominais: “(...) todas essas litanias carnais, todas essas enumerações pagãs, essas torrentes de expressões, de palavras rolando como seixos, arrastando o leitor numa corrente louca, tudo isso se encontra em Rabelais". A rapsódia modernista seria como a fusão de duas obras clássicas do Renascimento francês, Défense et illustration de la langue française, de Du Bellay, e Gargantua, de Rabelais. Mas a Idade Média do livro de Mário de Andrade seria "todo o período colonial, a monarquia, e o próprio começo da república”, durante os quais se formara a língua nacional. Cf. "Macunaíma visto por um francês", Revista do Arquivo Municipal, São Paulo, janeiro-fevereiro de 1946, p. 46ss. 
substantivos apenas uma função ornamental. Sua quantidade além do comum parece comunicar algo, como um pisca-pisca. Tomemos três exemplos:

I) Nos machos guspia na cara. Porém respeitava os velhos e freqüentava com aplicação a murua a poracê o torê o bacororô a cucuicogue, todas essas danças religiosas da tribo ${ }^{117}$;

II) E eram muitos mosquitos piuns maruins arurus tatuquiras muriçocas meruanhas mariugüis borrachudos varejas, toda essa mosquitada ${ }^{118}$;

III) Jiguê viu que a maloca estava cheia de alimentos, tinha pacova tinha milho tinha macaxeira, tinha aluá e cachiri, tinha maparás e camorins pescados, maracujá-michira ata abio sapota sapotilha, tinha paçoca de viado e carne fresca de cutiara, todos esses comes e bebes bons ${ }^{119}$.

O exemplo I constitui a primeira enumeração do livro. Em nota da edição crítica, é esclarecido que a seqüência designa danças de nações indígenas diferenciadas, às quais não diz respeito, por sua vez, a tribo fictícia de Macunaíma, tapanhumas ${ }^{120}$. Este nome, de acordo com o glossário de Cavalcanti Proença, indica especialmente os negros que moravam no Brasil, "os pretos civilizados"121. De fato, o narrador fala de Macunaíma como "preto retinto", que morava num mucambo (quilombo) e que "[embora numa indígena pajelança] Rei Nagô fez um discurso e avisou que o herói era inteligente" ${ }^{122}$. Mas numerosos dados de culturas autóctones, além dos vocábulos majoritariamente tupis para designar elementos da paisagem, se juntam

${ }^{117}$ Macunaíma, p. 6.

${ }^{118} I d$., p. 15.

${ }^{119} I d .$, p. 19.

${ }^{120}$ Id., p. 8n.

${ }^{121}$ Teschauer teria registrado o termo, apoiado em Alberto Rangel, como sendo de origem tupi: "de tapuy-una, o bárbaro preto, o contrário de tápuitinga, gente branca, às vezes aplicado à gente européia”. Cf. Cavalcanti Proença, op. cit., p. 300.

${ }^{122}$ Macunaíma, pp. 5, 6 e 8, respectivamente. 
aos de cultura africana: a dança bacororó pertence aos índios bororos, a murua aos taulipangues, a cucuicogue aos cucuígogues, e assim por diante ${ }^{123}$. Ou seja, a breve menção a um caso, raro, de assiduidade da parte de Macunaíma já é uma salada. No entanto, embora seja sincrética, não forma uma enumeração caótica, como os exemplos II e III não o formam também. Nestes, boa parte das palavras soam como “exóticas" (assim ocorria com a série de frutas analisada no início desta seção), mas elas estão de fato agrupadas conforme um campo semântico comum. Num caso, estamos apenas diante de mosquitos; no outro, apenas diante de comes e bebes. Rematando os dois, a anáfora tradicionalmente resumidora (e organizadora) do tipo “tout cela”, usada por Mário na maioria das suas listas ${ }^{124}$. No exemplo II, porém, ocorre algo semelhante ao que dizíamos a propósito da série de frutas e que é a prática mais comum no livro, ou seja, a soma nominal dos significantes excede a dos significados líquidos. As palavras estão misturadas a sinônimos ou variações que paradoxalmente pretendem multiplicar as coisas. Fala-se de pium, maruim, tatuquira, muriçoca, meruanha, mariugüi, borrachudo, vareja, mas pium é o mesmo que borrachudo e mariugüi é variante de maruim. Quase o total dos termos é tupi embora muriçoca, e talvez maruim, seja corrente na linguagem cotidiana, se não do Brasil de um modo geral, ao menos de certas regiões -, e as exceções são os populares borrachudo e vareja, com os quais nos sentimos mais à vontade (nos índices de Macunaíma, sempre haverá desses termos a que nos apegamos para nos salvar do dilúvio de obscuridades). O mesmo ocorre no exemplo III: entre pacova, macaxeira, cachiri, mapará, camorim, maracujá-michira, abio, paçoca, cutiara, ou cutiaia, sapoti (que é nauátle, mas tem gosto de tupi e de exótico), alguns são ${ }^{123}$ Cf. o glossário de Cavalcanti Proença. Quanto ao torê, o glossário da edição crítica traz mais informações que aquele. O Aurélio informa que se trata de 1) "dança selvagem, semelhante ao coco, pela coreografia e pela música"; 2) "cerimônia religiosa dos índios pancarus", em Pernambuco; e "dança guerreira e canto dos caboclos, ao som de pífaros e trombetas, durante o auto dos quilombos", em Alagoas. Esse último sentido aponta uma formação já sincrética.

${ }^{124}$ Spitzer discute as enumerações resumidas por tudo. Ver, da op. cit., p. 330 em diante. 
imediatamente familiares, outros, e para mim é o caso de mapará, abio, camorim, michira, cutiara, não saem do estado de música. Se ocorrer de um leitor achá-los fáceis aqui, infalivelmente não os achará em outras partes do livro, que reúne porandubas gaúchas, caxinauás, guaranis, quimbundas, potiguares, amazonenses etc., etc., etc. E, não sendo especialista, dificilmente ele conhecerá todos os termos tupis, responsável pela quase totalidade da estranheza das palavras. É verdade que são nativas, mas, como avisou Mário no quaresmiano "Lundu do escritor difícil": “de tão fácil [de tão nosso] virou fóssil”. Escrevi quaresmiano: em Macunaíma estão preservadas, às vezes modificadas, determinações contidas em Policarpo Quaresma. A luta inglória que este trava com as saúvas num dos capítulos finais do romance se pulverizou na rapsódia inteira em fileiras e fileiras de himenópteros de todo tamanho, cor e espécie. Desfilam em incontáveis enumerações e repetições, são como Leitmotive, bordam a narrativa e, como a formiguinha sarará Cambgique, que ajuntou o sangue espalhado de Macunaíma ${ }^{125}$, colaboram para dar unidade ao livro. Fazem as vezes de ajudantes mágicos e bem-dispostos, pimenta de gigante, armas letais, demolidores insidiosos. A diversão do herói desde criancinha é cortar cabeça de saúva ${ }^{126}$. E sua grande criação, registrada no livro de visitantes do Instituto Butantã, talvez tenha sido o dístico, na verdade uma colagem, "Muita saúva e pouca saúde,/ os males do Brasil são" ${ }^{127}$. Conforme uma opinião pouco lisonjeira para o Brasil naquelas décadas, com fundo realista mas com a pretensão de um hipocondríaco, o país não passava de uma montoeira de formigas, as quais

\footnotetext{
${ }^{125}$ Macunaíma, pp. 44-45.

${ }^{126}$ Macunaíma, p. 6.

127 "Este dístico é que houvemos por bem escrevermos no livro de Visitantes Ilustres do Instituto Butantã, quando foi da nossa visita a esse estabelecimento famoso na Europa" (Macunaíma, p. 83). O "ilustres" talvez seja por conta do pedantismo que, na hora de escrever, toma o corpo do herói, este uma "metamorfose ambulante", coringa para todo jogo (classe, geografia, patologia, período histórico). Essa é a sua falta de caráter. Lançar frases em livro de visitantes é bem alegria de pobre.
} 
revelavam mais método do que o agricultor, caipira ou ex-escravo ${ }^{128}$. Habituado ao uso do solo que a economia com base na monocultura e na ocupação extensiva da terra o levara a praticar em roças de (parca) subsistência e desamparo técnico, as quais eram a periferia do sistema agroexportador, ele era tragado pela natureza. Ainda que em graus diversos e com raras exceções, um baixo nível de racionalização caracterizava o sistema e a periferia. Monteiro Lobato percebera esse "estado de natureza" renitente pouco depois que tivera fim o folguedo do café no Vale do Paraíba ${ }^{129}$. A desesperança da seguinte passagem de Lima Barreto continua,

${ }^{128}$ Essa hipocondria, tal como grassou por aqui, alimentada por positivistas, eugenistas e higienistas, está em sua própria pele, ou seja, em retórica bacharelesca, à Godofredo Rangel, na "Carta às Icamiabas": "Inda tanto nos sobra, por este grandioso país, de doenças e insectos por cuidar!... Tudo vai num descalabro sem comedimento, estamos corroídos pelo morbo e pelos miriápodes!” (Macunaíma, p. 82). Esse estado depressivo sem dúvida está difundido no livro de um modo geral (Macunaíma é um catálogo de doenças do terceiro mundo), mas virou uma figurinha de folclore, como o pernosticismo, a cultura de bacharel, o título de doutor e o anel de grau, o escrever numa língua e falar em outra, os políticos do Brasil (os quais o Autor incluía inicialmente num engraçado bestiário - que muito lembra a História do Brasil, do poeta Sebastião Nunes -, depois suprimido, cf. Macunaíma, p. 86), as perninhas em arco de um subnutrido Macunaíma, o progresso técnico, a frase lapidar, a mania de discursos e as palavras destituídas de função comunicativa, a Bolsa, São Paulo, por fim transformada em pedra, a indisciplina e o caráter pouco afeito ao método, a mania de adivinhação, o desapreço pelo estudo e a admiração do talento espontâneo, o funcionalismo público ("muitos funcionários públicos", conforme um estribilho no livro), a "ética de fundo emotivo", a preguiça mental e a "moral da senzala", o "horror às distâncias", à formalidade, a falta de espírito público, a confiança na sorte, a falta de projeto, o capitalismo de aventura, toda a espécie de ontologia do ser social brasileiro que Raízes do Brasil sintetiza a partir de numerosos estudos anteriores, otimistas e pessimistas, sobre nosso caráter nacional e busca superar. Em Macunaíma, tudo, realidade e afastamento da realidade, cotidiano e artifício, recebe uma tonalidade harmoniosamente fantasmagórica. Como já disse, essa harmonia é lingüística.

129 Assim ele escreveu, em 1906, a propósito dos surtos de evolução econômica no Brasil: "[O progresso] emigra, deixando atrás de si um rastilho de taperas. // (...) Léguas a fio se sucedem de morraria áspera, onde reinam soberanos a saúva e seus aliados, a samambaia. Por ela passou o Café, como um Átila. Toda a seiva foi bebida e, sob a forma de grão, ensacada e mandada para fora. Mas 
embora se junte a outras num caudaloso coro, no romance de Mário: "Houve um instante de desânimo na alma do major. Não tinha contado com aquele obstáculo nem o supusera tão forte. Agora via bem que era a uma sociedade inteligente, organizada, ousada e tenaz com quem se tinha de haver. Veio-lhe então à lembrança aquela frase de Saint-Hilaire: se nós não expulsássemos as formigas, elas nos expulsariam. O major não estava lembrado ao certo se eram essas as palavras, mas o sentido era, e ficou admirado que só agora ela lhe ocorresse". Decerto há reminiscências em Macunaíma do professor de Quaresma, o músico popular Ricardo Coração dos Outros - como este, é também "coraçãozinho dos outros"130 e afeito a violinha. A Carta às Icamiabas tem algo do Requerimento do major, e as tentativas de abordar o gigante não lembrariam as de Policarpo de obter uma audiência com Floriano Peixoto se este não tivesse a pompa de um grão-vizir obscuro em seus desígnios e mutismo, quase tão fabuloso e caricato como Venceslau Pietro Pietra (que, por acaso ou para fazer graça, tem o prenome exótico de um presidente da República do Café, Venceslau Brás, o violento repressor da grande greve de 1917 e do Contestado). Pelos estudos brasilianistas em que se aplicou Quaresma também passou Mário ${ }^{131}$, lhes acrescentando muitos outros e, se nunca pretendeu pleitear o

do ouro que veio em troca nem uma onça permaneceu ali, empregada em restaurar o torrão. Transfiltrou-se para o Oeste, na avidez de novos assaltos à virgindade da terra nova; ou se transfez nos palacetes em ruína; ou reentrou na circulação européia por mão de herdeiros dissipados”. Cf. Cidades mortas [1919], São Paulo, Brasiliense, 1956, p. 3 e p. 6.

${ }^{130}$ Macunaíma, p. 11.

131 "De História do Brasil, era farta a messe: os cronistas, Gabriel Soares, Gandavo; e Rocha Pita, Frei Vicente do Salvador, Armitage, Aires do Casal, Pereira da Silva, Handelmann (Geschichte von Brasilien), Melo Morais, Capistrano de Abreu, Southey, Varnhagen, além de outros mais raros ou menos famosos. Então no tocante a viagens e explorações, que riqueza! Lá estavam Hans Staden, o Jean de Léry, o Saint-Hilaire, o Martius, o Príncipe de Neuwied, o John Mawe, o von Eschwege, o Agassiz, Couto de Magalhães e se se encontravam também Darwin, Freycinet, Cook, Bougainville e até o famoso Pigafetta, cronista da viagem de Magalhães, é porque todos esses últimos viajantes 
tupi como língua nacional, sem dúvida viu nele um material e tanto, suficientemente fóssil para produzir estranhamento e música. Essas possibilidades foram muito mal aproveitadas, por exemplo, no lamentável poema que saiu Cobra Norato, de Raul Bopp, cujo pastiche de ritmos, prosódias, elocuções, fraseados folclorizantes ou indígenas revela um ouvido de pedra - ou um estudo indecorosamente ligeiro, para o propósito que se tinha, das fontes primárias. Mário de Andrade pôde exibir em Macunaíma todo o seu gênio pastichador, toda a magnífica disponibilidade de seus sentidos, o que, porém, não significava deixar os materiais entregues a si mesmos. Sua colagem é em certo sentido preservada do irracionalismo dos ready-made mobilizados. A diligência, o comportamento ativo-subjetivo, com que são refundidos, com que motivos, diálogos, figuras de uns se deslocam para argumentos de outros e são ritmizados, com que fábulas prototípicas, comuns a contos da carochinha e a mitos ameríndios, são cruzadas e guarnecidas de frases feitas, provérbios, trovas, mitologemas, ou com que um material singular é apenas um esquema a ser encorpado, recheado e revitalizado com ficcionalização - como o próprio Macunaíma, ressuscitado mais de uma vez a partir da colagem de si mesmo com substâncias exteriores a ele, como guaraná, cola ou coco-da-Bahia - é muito responsável pela sensação de vividez de cada imagem, sempre transcrita por uma língua notavelmente homogênea. Essa homogeneidade da estilização, a desgeograficação lingüística, que obrigatoriamente leva à acronia lingüística (à indiferenciação entre etapas históricas do português), é em geral tão envolvente que mal nos permite que se vejam mesmo certas falhas (Macunaíma chorando no fim do capítulo, autoconsciência em relação à falta de projeto, "Pauí-Pódole", "Ci”, bumbameu-boi). Tal estilização, que parecia dizer que, ao menos em nível simbólico, o Brasil era apanhado de cima a baixo pela mobilidade técnica, não ficando de fora do empreendimento nenhum ermo ou socava, fosse talvez o "parque de transformação"

tocavam no Brasil, resumida ou amplamente. Além destes, havia livros subsidiários: dicionários, manuais, enciclopédias, compêndios, em vários idiomas" (Lima Barreto, op. cit., p. 17) 
que Oswald viu na rapsódia. Essa língua homogênea e homogeneizante - como um poema perfeitamente adaptado à música num bem composto Lied porque na verdade esta fora extraída daquele a partir de uma recitação obsessiva - jamais se repetiria dessa maneira em sua obra e com tal uniformidade quanto à excelência obtida. Uma razão é que o idioma dos materiais folclóricos já continham as virtualidades em que a prosa do livro agora prima: visualidade, certa graciosidade no uso de preposições e advérbios, vocativos engraçados como o indígena cunhado, parataxe, musicalidade, a maneira de falar por rimas (Que pena, sinh'Helena!), o gosto por diminutivos; a outra é que Mário as explorou ao máximo, concentrou em centímetro quadrado o quanto pôde essas virtualidades, em geral presentes a espaços, tão esparramadas em cada exemplar a ponto de as narrativas serem antes anêmicas e abstratas de feição (como o registro de Koch-Grünberg reproduzido no início deste estudo). Para isso se valeu da mais extrema liberdade para deslocar ênfases (tornar o essencial inessencial e vice-versa), dissolver, fixar, condensar, abreviar, contrastar, inverter ou dispor teleologicamente (os acontecimentos), estender, selecionar, excluir, acelerar, retardar. Utilizo os termos de Lukács ao descrever a gênese das categorias estéticas a partir do ritual mágico, ou seja, a gênese da mímese artística a partir da mímese mágica. A categoria formal da fábula, por exemplo, como foi exposta por Aristóteles no capítulo VI da Poética, derivaria do princípio de concentração espacial e temporal na magia: "O sentido da concentração advém do fato de que, para alcançar a finalidade mágica, devem-se apresentar os momentos importantes da vida de um modo abreviado, comprimido, que sublinhe energicamente a essência"132. A entonação ("portadora da essência da generalização artística" e especialmente importante na lírica e na música) como o episódio, a complicação, o retardamento, o contraste, a reação, a suspensão constituem outras tantas categorias artísticas, já em germe no processo mágico e que teriam por finalidade também acentuar, para a

${ }^{132}$ Lukács, "Magie und Mimesis", Ästhetik I, p. 394. 
percepção, o conteúdo arrancado à imediatez da vida cotidiana ${ }^{133}$. A passagem da formação mágica, "ainda presa à superfície sensível da vida”, para a formação artística ocorre mediante a penetração de conteúdos sociais, os quais, por sua vez, adquirem outro padrão qualitativo no interior da mímese. Mas o processo crescente de autoconsciência da humanidade é acompanhado pela autonomização da configuração artística em relação à magia, pois os novos conteúdos apreendidos pela consciência também obrigam a uma alteração qualitativa da forma. Estão latentes nos significados abstratos as possibilidades formais de os dispor para a percepção, de construir sua aparência sensível. Gilda de Mello e Souza qualificou o processo de criação em Macunaíma de parasitário, por oposição a mimético: ele não transcreveria tendências do mundo objetivo, mas se ligaria a outros mundos ficcionais, a outras formas autônomas ${ }^{134}$. No entanto tal método parasitário, prossegue, é na verdade inventivo (pressupõe um sujeito), pois quase sempre cada retalho submete-se à coação artística, não permancendo neutro ou inalterado. Por tal razão é que a técnica usada não seria a do mosaico ou a da bricolagem; estas suporiam de uma maneira ou outra uma "sensibilidade passiva", o que esse livro "intencional e cheio de ressonâncias"135 parece contradizer. Cheio de ressonâncias

${ }^{133}$ Lukács, pp. 420-421.

${ }^{134}$ Gilda de Mello e Sousa, O tupi e o alaúde, p. 10.

${ }^{135}$ Para a autora, parte dessa intencionalidade seria manifesta, por exemplo, na alegoria do capítulo "Vei”. É sabido que, entre as objeções que Gilda de Mello e Souza faz a Morfologia de Macunaíma, de Haroldo de Campos, está a de que essa interpretação, presa ao modelo do conto de magia russo estabelecido por Propp a partir de uma longa pesquisa estatística, não reconhece à "Carta", "como, aliás, grande parte dos amigos e contemporâneos do escritor”, uma função estrutural, mas antes ornamental, "pura exibição de virtuosismo lingüístico, quando era na verdade um comentário satírico da escolha desastrada do herói que acaba de preferir a portuguesa às filhas de Vei”. Em nota a esse comentário, é lembrado como as opiniões dos companheiros de geração de Mário de Andrade ficaram bastante divididas a respeito do que a muitos parecia mero apêndice, entre os quais se contava justamente Manuel Bandeira. Haroldo de Campos apurou um grande sintagma na estrutura geral do romance; Gilda de Mello e Sousa, dois sintagmas: um conduz ao triunfo e outro à derrota. 
Este último tem no centro o episódio de Vei. Contudo não seria mais exata a percepção de um eixo organizador, embora tênue e reiteradamente interseccionado por outras linhas que chegam a embaçar sua definição? Vei de fato é traída, ou, conforme a interpretação alegórica, as civilizações tropicais e, por extensão ou inclusão, a cultura brasileira é traída? Sim e não. Mário fala no segundo prefácio em “A simbologia é episódica, aparece por intermitência...” (cf. Marta Rossetti Batista, op. cit., p. 293). O capítulo "Pauí-Pódole", que se segue ao episódio de Vei e à Carta, mostra um Macunaíma extremamente (piegasmente, na verdade) patriótico. Ele polemiza com o mulato orador a respeito da origem da constelação do Cruzeiro e então narra a história do Pai do Mutum (que, em reconhecimento a isso, faz a feitiçaria, no último capítulo, que permite o herói se transformar em Ursa Maior). Macunaíma renega uma de suas filhas? Parece antes que ele simplesmente não recusa nenhuma "cunhã" que cruze seu caminho. É verdade que acaba por dormir com uma portuguesa, mas logo de madrugada a abandona, e ao próprio cavalheirismo, num banco do Flamengo quando deste se aproxima a impressionante assombração Mianiquê-Teibê, que por fim engole a peixeirinha (será aqui Mianiquê-Teibê um trombadinha, ou um assassino a que a corrente de relatos mítico-populares, mimetizada por Mário de Andrade, procurou fazer justiça por meio de encadeadas e assustadas hipérboles?). Se as filhas da Sol não se importassem, é provável que ele voltasse a cair em seus braços multiplicados de carícias. Fora mais "pra não desmentir a fama" que o personagem não se permitiu inibir pela promessa e ficar "monogâmico". Como realçar tanto a traição às civilizações tropicais, supostamente ratificada pela linguagem usada na correspondência com as icamiabas, se ele continua empenhado em ter consigo a pedra fabulosa de nome tupi e mal ou bem não esquece a sua "marvada"? Repare-se que uso realçar porque não pretendo negar o trato não cumprido (entre tantos no livro), mas apenas fazê-lo não pesar tanto no cálculo geral a ponto de o hipostasiar, atribuindo-lhe o mesmo papel organizador do qual, com muitos abalos, o esquema carência/reparo ainda tem o monopólio. Há elementos que impedem essa formação de relevo. Assim, Vei, apesar da decepção, não comete a gentileza de dar ao tapanhumas embranquecido um presente útil, a pedra Vató, depois trocada por um retrato no jornal (talvez porque não fosse mais útil na cidade, mas Vei decerto não soubesse que tinha expirado sua data de validade..)? Quando a boa mãe resolve dar um escaldão no herói, este já não era um "defunto sem choro" (p.158), e não se tinha tornado evidente que jamais voltaria a ser "marupiara"? (Na verdade, tudo isso é reconhecido por Gilda, que com toda a razão usa isso como prova, contra a interpretação de Haroldo, de que o percurso final de Macunaíma não é de maneira alguma triunfal; Dona Gilda tem toda a razão em ver um pressentimento de derrota). Sua desforra, efetivada exatamente quando Macunaíma está diante de um lago com piranhas, bem "no pino do dia" (= "Vei estava zangadíssima", p.162), vem a ser mais um "só o que me faltava", como 
sem dúvida - mas elas são de natureza mimética e certamente são engendradas porque está em jogo não uma atitude passiva ou meramente lúdica em relação aos dados preliminares, mas um modo diligente-subjetivo. Trata-se da reelaboração de cada fragmento, para tornar mais uma vez à afirmação preciosa da autora, reelaboração que toma a medida de comprimir, retardar, acelerar, complicar, deslocar acentos, reproduzindo, em relação a sistemas de sinais autônomos, é verdade, a gênese dos processos estéticos descrita atrás. Mas essa reprodução, essa imitação de segundo grau, está pejada de referências ao mundo objetivo, posto que sejam profundamente mediadas, daí por que se mostra árduo o trabalho de detectálas analiticamente. Não é vão, porém, esse trabalho, pois que as sentimos e devem ser reais. Para Gilda, o aspecto subjetivo se trairia em especial nos propósitos flagrantes de alegorização ou de paródia - a esta dedicará a última divisão de seu estudo. As partes foram aplicadamente modificadas para atender a intenções e projetos. Creio que tudo isso é verdade, sobretudo num autor tão comprometido com a atualização cultural, com o modernismo nacionalista e, naquela altura, com a

tinham sido antes as cagadinhas de urubu na sua cabeça depois de o ter atirado na Baía de Guanabara a árvore Volomã, cagadinhas que o contrariariam a ponto de querer desistir desta vida e pedir à Caiuanogue que o levasse para o céu., que não o levou, porém, como a Lua também não o levou, pela mesma razão e simetria que uma e outra não o farão no capítulo final: ele fedia mal. Enfim, a punição infligida pela "velha vermelha" seria - posso estar enganada - mais da ordem "desgraça pouca é bobagem". É bem verdade que esse evento faz a muiraquitã ir parar, agora definitivamente - para a história de Macunaíma ao menos - na barriga do monstro Ururau (p. 164), mas ela já não valia tanto mesmo... Portanto, com base na notavelmente produtiva para a reflexão sobre a rapsódia e sobre Mário de Andrade que é a primeira parte de $O$ tupi e o alaúde, inclino-me a concordar mais com Haroldo de Campos, que porém enrijece, fetichistamente, o plano narrativo tradicional, perda-reparo, devido a seu parti pris. Tudo isso para mostrar como pode ser traiçoeiro o terreno das alegorias no livro. D todo modo, Ci, a quem Macunaíma não esquece, é Imperatriz do Mato Virgem, um mato brasileiro - ou brasilo-guianense, ou latino-americano, ou qualquer coisa a que para chegar não se dependa do mar. Macunaíma é fiel a algo mais ou menos autóctone, ainda que vago e tremebundo como uma estrela, ou como a lembrança de uma vida aprazível que já passou. 
pesquisa do caráter nacional brasileiro como Mário de Andrade, cujo primeiro romance, conforme ele sempre declararia, fora um "livro de intenções"136. O que não fez que Amar, verbo intransitivo, uma obra bastante inferior a Macunaíma e com muito menos ressonâncias, não fosse apenas um reflexo ou um apanhado das preocupações (ao menos as imediatamente divulgadas) do escritor naquele momento. Não são apenas motivos alegóricos ou paródicos que dificultam a redução ao esquema do conto de magia russo - ou do conto de qualquer outra tradição, ou a um fato de langue enfim ${ }^{137}$, como pretendeu Haroldo de Campos. Certamente o

${ }^{136}$ Os personagens paulistas e ricos de Amar, especialmente o adolescente Carlos, já portavam traços do herói sem caráter - este um herói reconhecível em todas as classes, portanto, ou súmula dos maus condicionamentos mentais de que nenhuma classe no Brasil estaria livre.

137 Embora também se busque investigar os fatos da langue através da mimetização de seus mecanismos. Ou seja, reatualiza-se o processo no qual a experiência historicamente localizável da segregação social foi despojada de concreticidade até emergir em forma por assim dizer atemporal, como fato da língua, como "forma simples" (na conceituação de André Jolles). Esse atemporal carrega índices, "cabeças mortas", do temporal. A liberação do conteúdo se efetivaria aproximativamente, por ressonâncias. Podemos fazer sobre Macunaíma algumas das perguntas que Renato da Silva Queiroz fez sobre o saci: por que ele é negrinho? Por que é maroto e malévolo? Por que embaraça a crina dos cavalos? O antropólogo pôde levantar algumas hipóteses por meio de inquérito com populações mais antigas de cidades paulistas e por meio de folcloristas: "As fontes consultadas situam as primeiras aparições do saci-moleque (cujas aventuras, tudo leva a crer, estão restritas à área de influência paulista) a partir da segunda metade do século XVIII". Construto da cultura caipira, o saci depõe sobre a maciça formação de latifúndios (por compra e extorsão de posseiros e proprietários menores) e a presença mais palpável, aos olhos dos paulistas empobrecidos, do trabalhador escravo. "Para o caipira dessa época a figura do Saci-moleque não poderia expressar, a um só tempo, as representações negativas referentes ao negro, as ameaças que caminham com a expansão dos latifúndios e, por confronto, os limites de seu próprio universo?”. Ver, do autor, Um mito bem brasileiro - estudo antropológico do saci. São Paulo, Polis, 1987, pp. 88-89. O aspecto diabólico desse personagem é assim explicado por um dos entrevistados: "É fio dessas negras desavergonhadas, que fica grave, dispois fica co medo das sinhá; porque às veis o fio é do próprio sinhô ou do sinhô-moço, e vai largá no mato; morre pagão e vira Sacy” (op. cit., p. 64). Quanto à crina dos cavalos, parece haver aí, segundo o autor, uma transferência de afeto, destinado antes ao 
espírito de sátira impregnado no livro colabora para que lhe seja muito realçada a tendência alegorizante. Para falar nos termos do idealismo alemão: na sátira a ênfase

cavaleiro, o explorador. O povo que anda a pé se desforra com as maldades feitas ao animal que, "mais do que qualquer outro, [está] a serviço do domínio do indivíduo sobre a massa", nas palavras de Gilberto Freyre (apud Renato da Silva Queiroz, op. cit., p. 85). Como o mito do saci, o bumbameu-boi (que merece uma inserção desmesurada no capítulo "Uraricoera", o que muito irritou Bandeira) propiciaria uma catarse coletiva semelhante: "Não seria outra a intenção dos oprimidos trabalhadores dos engenhos de açúcar nordestinos quando, nos espetáculos do 'Bumba-meu-boi', tratam de depreciar o cavalo - símbolo da exploração - valorizando um outro animal -o boi, símbolo do trabalho (...)" (op. cit., 87). Como se nota, no saci parecem fundidos tanto a depreciação que o explorado (caipira ou escravo) faz do explorador (senhor de engenho), é o que mostra a relação com o cavalo, como a depreciação que os caipiras fazem de outros mais explorados ainda, os escravos. A imagerie de Macunaíma e a do Gigante Piaimã, como Mário os recriou, também reúnem atribuições de estratos sociais diferenciados. E nisso o Autor mimetizou o processo popular descrito. Quanto ao Gigante, vamos aproveitar a citação do próprio antropólogo: "Maanape fez um discurso mostrando as inconveniências de ir lá porque o regatão andava com o calcanhar prà frente e si Deus o assinalou alguma lhe achou. De certo um mauarí malevo..." (apud op. cit., p.63n). Queiroz menciona esse trecho quando aborda um dos estigmas do saci: a falta de uma das pernas, o que o faz claudicar. A deformidade física, lembra o pesquisador, pode indicar vizinhança com o demônio, o que a expressão popular "quando deus marca, não é à toa" confirma e Mário de Andrade reproduziu em relação ao ogro da rua Maranhão. A frase "si deus o assinalou alguma lhe achou" é evidentemente preconceituosa, mas seu uso aqui, não totalmente aclimatado - o que é comum na colagem, procedimento do qual o livro busca ter uma profunda autoconsciência, o que produz um efeito algo diverso do caso em que meramente o utilizasse -, talvez sirva para ativar um preconceito defensivo. Seja como for, Mário dá a honra da literalidade ao ditado, isto é, o ilustra com todo o esmero. Quanto a Macunaíma, lembremos que ele termina capenga, com um perna direita comida pelas piranhas. De fato, Caiuanogue, a estrela-da-manhã, lhe pergunta: "Que é que quer, saci?". (Macunaíma, cit., p.166). Não fosse pela cor branca, Macunaíma é o tal mesmo, ao menos por esse momento. Uma pergunta também devemos fazer: por que ele passa de preto a branco? Costuma-se tomar em nível muito genérico a questão das raças no livro, quando a referida passagem indica um fato concreto, relativo ao cotidiano dos descendentes de escravos: Macunaíma fica branco por sorte, ou melhor, por ter se banhado em água encantada. No Brasil, um preto ficar branco é visto mesmo como sorte - ou milagre, pelo qual muita mãe grávida e apreensiva pelo futuro do filho deve ter rezado. 
tende mais para o entendimento, para a idéia abstrata, que para a aparência sensível, contra a qual se volta punitivamente ${ }^{138}$. De um modo genérico, Macunaíma nos faz rir da matéria com relação à qual Paulo Prado, em Retrato do Brasil, pretendeu nos fazer chorar. Como o ensaio, a sátira quis nos distanciar, sem nos subtrair ao prazer estético, porém, da lamentável realidade de que fazia alarde o pensamento social crítico da época, ao qual dava razão. Não obstante, é preciso levar em conta, com Alfredo Bosi, que ela "se disfarça e se atenua em meio a brincadeiras de linguagem e de construção. Se o lastro 'negativo' não fosse contrabalançado pela adesão lúdica e simpática à mente selvagem, o sentido último de Macunaíma se cifraria na mais cáustica das acusações já movidas às mitologias do caráter nacional brasileiro"; contudo as coisas não se passam exatamente assim, pois "a memória afetiva (...), investida de um pathos fortíssimo, foi trazendo para o interior da rapsódia um quase infinito viveiro de imagens e cenas, ritos e lendas, frases e casos que constituíam o seu mais caro tesouro, a fonte inexaurível do seu populário luso-afro-índiocaboclo..."139 . Esse viveiro de imagens e cenas, ritos e lendas e, mais do que isso, o empenho em multiplicá-las - por centímetro quadrado mesmo, e não há hipérbole nisso - e dotá-las de nitidez, de fazê-las rebrilhar de uma maneira inédita, tirando partido de suas potencialidades, como procurei mostrar no início deste trabalho, fez o livro se saturar de concretos. Uma das perspectivas amplamente exploradas foi o

\footnotetext{
${ }^{138}$ Hegel a situou no processo de dissolução da arte clássica, vista como unidade entre forma exterior e significado espiritual ("formação-em-um do particular e do universal”, conforme Schelling). Diferentemente da arte simbólica, no entanto, em que a abstração está em busca da aparência, não tendo podido ainda determiná-la a partir de si mesma (e toda associação com formas é por isso deficiente), na passagem para a arte romântica, na qual a sátira é produzida, a abstração a rejeita. A expressão sensual é sobrepujada pela interioridade excessiva ("insatisfeita”). Cf., de G. W. F. Hegel, "Introdução" e "A dissolução da forma de arte clássica”, in Cursos de estética II (trad. Marco Aurélio Werle e Oliver Tolle), São Paulo, Edusp, 2000.

${ }^{139}$ Alfredo Bosi, "Situação de Macunaíma”, in Macunaíma, pp. 176-177.
} 
“excesso de substantivos das línguas primitivas" "140, mais próximas da percepção sensorial e mais distantes do conceito, da intrincada síntese de mediações relativas a um objeto, ação ou fenômeno ${ }^{141}$. O que não quer dizer que não haja nelas uma tendência para a abstração. Como nota Lukács, o fato de que, segundo Lévy-Bruhl, a cor negra, por exemplo, não exista entre certos povos não civilizados, que apenas a identificam na referência a objetos negros ou no contraste com objetos de outra cor, indica tanto uma conexão mais imediata com a práxis como já uma disposição para o conceito, apegada, porém, às coisas do cotidiano ${ }^{142}$. A generalização preto se vale da compilação de muitos particulares com essa cor. Pertence a essa ordem de raciocínio a observação de Lévi-Strauss de que o pensamento selvagem se vale de atributos concretos, cru e cozido, mole e sólido etc., como categorias descritivas de processos mais complexos. Certamente os hieróglifos são antecedentes dos substantivos, que dão parte de um nível maior de generalização e afastamento da imediatez que os caracteres sensíveis em que se constituem os ideogramas. O aspecto por assim dizer tangível da escrita pré-sintética de certas sociedades mais antigas, era o caso de algumas tribos indígenas ameríndias, também foi aproveitado por Mário ${ }^{143}$. Referi-me a isso quando tratava da ausência de vírgula nas enumerações. Nesse caso específico, a falta do sinal alude a recursos icônicos, da escrita analítica, no interior de uma escrita já sintética. Mas de fato muito mais hieroglífico em si mesmo é o epitáfio dedicado à mãe de Macunaíma ${ }^{144}$. Também se

\footnotetext{
${ }^{140}$ Lévy-Bruhl, La mentalité primitive, Paris, Libraire Félix Alcan, 1922, p. 234.

${ }^{141}$ A esse respeito, cf. Lukács, Ästhetik I, p. 57 em diante.

${ }^{142} I d$., ib., p. 58.

${ }^{143}$ Há uma enumeração de sítios com tais inscrições: "Passando no Ceará decifrou os letreiros indígenas do Aratanha; no Rio Grande do Norte costeando o serrote do Cabelo-não-tem decifrou outro. Na Paraíba, indo de Manguape pra Bacamarte passou na Pedra-Lavrada com tanta inscrição que dava um romance (...)" etc. Op. cit., p. 107. Antes se fizera menção a "pedras cheias de letreiros encarnados da gente fenícia" (p. 104).

${ }^{144}$ Macunaíma, p. 20.
} 
pode mencionar, conquanto valham em grau menor e como tendência, as palavras, inopinadamente aumentadas e desgarradas do corpo mais corrido do texto, que formam o epitáfio - sem pontuação de fim - do próprio personagem, o famoso Não vim ao mundo para ser pedra ${ }^{145}$. Para Eneida Maria de Souza, adquire forma icônica essa inscrição, gravada numa laje que, esclarece o narrador rapsódico, "fora jabuti num tempo muito de dantes"146. A saturação de concretos no livro se dá como saturação de substantivos, de enumerações. Isoladamente consideradas, não são caóticas. Não seriam disjuntivas, e sim conjuntivas, para falar com Spitzer, que ressalva como os elencos em Rabelais tinham propósito construtivo: explorar ao máximo a riqueza nativa da língua. $\mathrm{O}$ que Bastide e Bandeira reconheceram ser o caso em Macunaíma. Quando lemos, por exemplo, “A ruivor veio vindo veio vindo e era o bando de araras vermelhas e jandaias, todos esses faladores, era o papagaio-

${ }^{145}$ Macunaíma, p. 165.

146 “A pedra mágica do discurso", in Macunaíma, p. 306. Como a autora, eu também falaria em "petrificação dos signos" e "petrificação-animada dos signos"; na suplantação da falta de coisas através de coleções de palavras (p. 301); na circulação de signos como moedas (p. 297); em “comércio significante" (p. 298). Mas sua leitura, ou os métodos em que ela se cerra, não vê problema no irracionalismo que essas formulações estão apontando, ou não se pergunta por que Mário investiu os significantes de tal autonomia. Na verdade, diz a crítica, o sujeito é aqui ultrapassado pela enunciação (op. cit., p. 297) e aqui termina o problema - se o houve. Contudo a semiótica e o pós-estruturalismo lhe propiciaram a consideração de aspectos que se supunham de menor importância. Para Gilda de Mello e Souza, por exemplo, a experimentação lingüística do livro estivesse provavelmente datada. E na verdade, assim penso, é a cereja do bolo - ou o começo de tudo. Talvez a autora de $O$ tupi $e$ o alaúde precisasse saltar por sobre essa dimensão mais microscópica, a qual deixou aterrorizados ou admirados, mas sempre sob encantamento, os contemporâneos de Mário, se quisesse chegar a aspectos mais estruturais da composição, não arriscados pela recepção da obra em fins dos anos 20 ou nos anos 30, com uma exceção aqui e ali meio tímida. A exceção mais vigorosa veio mesmo do inteligentíssimo Manuel Bandeira. Haroldo de Campos, guiado pela morfologia de Propp e pelo estruturalismo, já tinha entrado por tal seara, confiscando ao romance, porém, o papel do sujeito - o romance de fato imitava a secular confiscação do sujeito no Brasil, do que a arte popular dava o seu testemunho como podia. 
trombetaera o papagaio curraleiro era o periquito cutapado era o xará o peito-roxo o ajuru-curau o ajuru-curica arari ararica araraúna araraí araguaí arara-taua maracanã maitaca arara-piranga catorra teriba camiranga anaca anapura canindés tuins periquitos, todos esses"147, é evidente que tais nomes exóticos roubam a cena. Os significantes lingüísticos de fato circulam como moedas aqui, conforme notou Eneida Maria de Souza. E produzem em nós uma sensação algo parecida à que temos com o merchandising que penetra o tecido do discurso em Berlin Alexanderplatz, por exemplo: "este era um tremendo gigolô, não queria nunca mais se meter com ele. E, braços dados, descendo a Prenzlauer Strasse, fábrica de licores, oficinas têxteis, confeitarias, seda, seda, compre seda, a mulher de personalidade usa seda". O que se alardeia, porém, é de ordem muito distinta num caso e outro - nada mais, nada menos que a ordem da natureza e a da cultura. Na verdade, não seria exato ver no primeiro caso uma divulgação do tipo "no tabuleiro da baiana tem". Porque menos do que a imagem mental das coisas, os referentes, importam mais os significantes, a excentricidade de seus sons e sua imagem gráfica, a qual acena para nós tão logo botamos o olho na página, como se quisesse adquirir relevo. Essa sensação é produzida pela imensa quantidade desses substantivos pesquisados, que, não apenas nas enumerações, chamam digressivamente a atenção, como a série, mais modesta em vários aspectos, "abóbora, chicória e cambuquira" no poema de Oswald analisado atrás. Basta que constem: "Jiguê não desconfiou de nada e começou trançando corda com fibra de curauá", "Iriqui pintava a cara com araraúba e jenipapo e todas as manhãs passava coquinho de açaí nos beiços”, “topou com o Currupira moqueando carne, acompanhado do cachorro dele Papamel”, "topou com a cotia farinhando mandioca num tipiti de jacitara", "então assoprou raiz de cumacá em pó que bambeia cordas", "mas não deu nem um tiquinho da pacuera assando no espeto de canela de sassafrás" ${ }^{148}$. Esse é o padrão das frases. Pode-se perguntar se

\footnotetext{
${ }^{147}$ Macunaíma, p. 138.

${ }^{148}$ Macunaíma, pp. 10, 15, 17, 18, 141.
} 
não nos acostumamos a ele. $\mathrm{O}$ caráter amplo da pesquisa nos entretém o tempo inteiro, as palavras inusuais mal se repetem. Cada elemento estranho ao nosso vocabulário, passivo ou ativo, tem vagueza e poder de sugestão, como tinham para Proust os nomes das estações de trem, de etimologia quase inapreensível, em Sodoma e Gomorra. Quanto menos desconfiamos de seu sentido, mais adquirem para nós o caráter de assunto (no sentido que, por oposição a tema, lhe deu o Autor), de imprecisão misteriosa. $\mathrm{Na}$ verdade, isso não acontece apenas com os substantivos: de tia Ciata se diz que era javevó e galguincha ${ }^{149}$. Ainda agora quando os vejo, esses termos justapostos, fechados em si mesmos como dois forasteiros, que não nos concedem nenhuma ajuda para adivinhá-los, parecem dois escudos no peito de tia Ciata. São qualificadores, mas seu caráter pesadamente enigmático faz deles duas coisas substantivas.

A ânsia inventariante do livro, um colorido catálogo, tem propósito sistemático, de esgotamento de possibilidades. Os concretos são exaustivamente compilados, como substantivos, e como estruturas, imagens e cenas. Nesse sentido é que disse páginas atrás que podíamos entender a enumeração nesse contexto também como suíte ou composição rapsódica. A metamorfose, um mitologema evidentemente presente numa narrativa com tantos feiticeiros, é mais uma força para a multiplicação de concretos, e, no cruzamento que Mário faz entre tantos documentos, essa força dobra. Hegel a abordou na seção dedicada à última fase da arte simbólica - a arte que ainda não realizou o conceito de arte propriamente -, ou seja, ao "simbolismo consciente da arte comparativa", dividido em dois estágios principais. Num, o fenômeno concreto é o aspecto mais destacado para a consciência, pois nesse caso "a atividade subjetiva de comparar" se desenvolveu menos; noutro, o significado é a parte mais pronunciada. A abstração é maior porque a operação comparativa está mais adiantada. Ao primeiro estágio pertenceriam a

${ }^{149}$ Macunaíma, p. 57. 
metamorfose, a fábula e o apólogo; ao segundo, a alegoria, o enigma e o símile ${ }^{150}$. O importante para o nosso caso é a compreensão da metamorfose como uma sequiência de ao menos duas imagens (trata-se de uma comparação, um tanto inconsciente de si, mais que o apólogo e a fábula) e como um grau de abstração mais baixo. No livro, o automóvel é automóvel e onça, Maanape é homem e telefone, Naipi é índia e cascata, Capei é Lua e serpente-dragão, Oibê é minhocão, lobisomem, cachorro-domato, borboleta azul e homem ${ }^{151}$, etc., e quase tudo "já foi gente um dia que nem nós"; e muitos seres podem virar constelação ou pedra. São fileiras de substantivos, e por vezes, raras é verdade, fileiras caóticas. Como Maanape, semelhante ao verso de Neruda, citado antes, entre magnólias e telegramas. Porém, como ocorre com os substantivos misteriosos do livro, o que mais chama a atenção nas metamorfoses é a sua quantidade. Nós as sentimos como uma corrente elétrica através da qual tudo desata a funcionar. As metamorfoses são o verdadeiro maquinismo aqui - uma força produtiva que multiplica imagens. Qual o sentido de tanta saturação? Macunaíma é uma extensa enumeração nominal, mas fundamentalmente de bichos, plantas, entes fabulosos, acidentes geográficos (“muitos funcionários públicos!" também). O ponto de vista primitivista faz que máquinas sejam processadas em termos de produtos primários, retirando-lhes todo o valor agregado. Tal é uma das primeiras impressões que Macunaíma tem de São Paulo:

Acordou com os berros da bicharia lá em baixo nas ruas, disparando entre as malocas temíveis. E aquele diacho de sagüi-açu que o carregara pro alto do tapiri tamanho em que dormira... Que mundo de bichos! Que despropósito de papões roncando, mauaris juruparis sacis e boitatás nos atalhos nas socavas nas cordas dos morros furados por grotões donde gentama saía muito branquinha branquíssima, de certo a filharada da mandioca!... A inteligência do herói estava muito perturbada.

\footnotetext{
${ }^{150}$ Hegel, op. cit., pp. 107 e 108.

${ }^{151}$ Macunaíma, p. 145.
} 
As cunhas rindo tinham ensinado pra ele que o sagüi-açu não era sagüim não, chamava elevador e era uma máquina $(. . .)^{152}$ etc.

Os edifícios são malocas, os elevadores sagüis, o ruído urbano ruído orgânico, as chaminés boitatás e assim por diante. Quando deixa a cidade, Macunaíma faz um caborje e a transforma num bicho-preguiça de pedra, o que talvez seja a síntese de um processo regressivo: cultura $\rightarrow$ natureza orgânica $\rightarrow$ natureza inorgânica. Segundo Marx, não se "produzem as abstrações mais gerais [mais complexas] senão onde existe o desenvolvimento concreto mais rico (...)"153. Macunaíma é colorido como um mosaico, vivaz, prenhe de coisas (nesse sentido, ele mais descreve do que narra); mas elas valem muito pouco, como os pescados e caças dos personagens, como o papiri que Macunaíma e os manos começam a construir para morar ${ }^{154}$. Sua quantidade imensa, porém, quantidade que aumenta com a decomposição de produtos complexos em objetos da natureza, deve significar que ela ainda não foi suficiente para atingir um nível mais complexo de abstração. As metamorfoses constantes e cumulações de concretos são como as lavouras de subsistência amplamente cultivadas para garantir a acumulação no novo sistema produtivo instaurado com a Revolução de $30^{155}$. (A continuar)

\footnotetext{
${ }^{152}$ Macunaíma, p. 40.

153 "Para a crítica da economia política", in Manuscritos econômico-filosóficos e outros textos escolhidos (Trad. de José Carlos Brunni, José Arthur Giannotti e Edgard Malagodi). São Paulo, Nova Cultural, 1987, p. 19.

${ }^{154}$ Macunaíma, p. 45.

155 Estou fazendo alusão à conhecida tese de Francisco de Oliveira conforme a qual a agricultura “primitiva” e certas formas da economia de subsistência, como o mutirão para construir a própria casa, teriam sido medidas fundamentais para a introdução e o êxito de um novo modo de acumulação de riqueza a partir da Revolução de 30. Numa economia de baixa capitalização como era a brasileira, a formação do lucro no setor emergente da indústria supunha um grande exército industrial de reserva e um baixo custo da força de trabalho. Para que se desse essa última condição, a agricultura teve
} 
função primordial, especialmente no setor de produtos para consumo interno, devendo "suprir as necessidades das massas urbanas, para não elevar o custo da alimentação, principalmente e secundariamente o custo das matérias-primas, e não obstaculizar, portanto, o processo de acumulação urbano-industrial". Ao lucro do empresário industrial estava ligada uma grande quantidade de lavouras de subsistência, de gêneros tão variados como até então não tinha havido (Crítica à razão dualista/ o ornitorrinco. São Paulo, Boitempo, 2003, pp. 42 e 43). Essa associação duraria enquanto o custo da reprodução da força de trabalho na cidade se mantivesse num nível incipiente de mercantilização e industrialização, isto é, dependesse ainda muito pouco de fatores urbanos (op. cit., p. 84). 


\section{Bibliografia fundamental}

Adorno, Theodor W. Noten zur Literatur I e III, Frankfurt am Main, Suhrkamp, 1969.

. Notas de literatura I (trad. Jorge de Almeida). São Paulo, 34/Duas

Cidades, 2003.

. Notes to literature (trad. Shierry Nicholsen), Nova York,

Columbia University.

Teoria Estética (trad. Ruy Mourão), São Paulo, Martins Fontes, 1988.

___ Dialética do esclarecimento (trad. Guido de Almeida), São Paulo, Zahar, 1989.

. Philosophie de la nouvelle musique. Paris, Gallimard, 1962.

____. Filosofia da nova música, São Paulo, Perspectiva, 2004.

___.Prismas (trad. Augustin Wernet e Jorge de Almeida), São Paulo, Ática, 1998.

Alencastro, Luiz Felipe de. "A pré-revolução de 30", Novos Estudos CEBRAP, $n^{\circ} 18$, setembro de 1987. “Proletários e escravos", Novos Estudos CEBRAP, n²1, julho de 1988.

Almeida, Renato. Manual de coleta folclórica. Rio de Janeiro, Gráfica Olímpica Editora, 1965.

Amaral, Amadeu. Tradições populares. São Paulo, Instituto Progresso Editorial, 1948. 
Anderson, Perry. "Modernidade e revolução", Novos Estudos CEBRAP, n.14, fevereiro de 1986.

Antunes, Ricardo. Classe operária, sindicatos e partido no Brasil. São Paulo, Ensaio/Cortez, 1988.

Andrade, Mário de. Amar, Verbo Intransitivo, Belo Horizonte/Rio de Janeiro, Villa Rica, 1995.

A Lição do Amigo. Cartas de Mário de Andrade a Carlos Drummond de Andrade. Anotadas pelo destinatário. Rio de Janeiro, José Olympio, 1982.

. Aspectos da Literatura Brasileira, São Paulo, Martins, s.d.

- Balança, Trombeta e Battleship, São Paulo, Instituto Moreira

Salles/ Instituto de Estudos Brasileiros, 1994.

_.Cartas Mário de AndradelOneyda Alvarenga, São Paulo, Duas

Cidades, 1983.

. Cartas a Murilo Miranda (1934/1945), Rio de Janeiro, Nova

Fronteira, 1981.

Cartas de Mário de Andrade a Prudente de Moraes, neto (1924-

1936). Organizado por Georgina Koifman. Rio de Janeiro, Nova Fronteira, 1985.

___.Contos Novos, Belo Horizonte, Villa Rica, 1993.

___.Correspondência - Mário de Andrade \& Manuel Bandeira, São

Paulo, Edusp/IEB, 2000.

.Correspondente Contumaz, Rio de Janeiro, Nova Fronteira, 1982.

____.De Paulicéia Desvairada a Café (Poesias completas), São Paulo,

Círculo do livro, 1985. 
___Entrevistas e Depoimentos (org. Telê Porto Ancona Lopez), São Paulo, T. A. Queiroz, 1983.

___ Macunaíma, ed. crítica de Telê Porto Ancona Lopez, Coleção Arquivos, Unesco, 1988.

. Mário de Andrade escreve cartas a Alceu, Meyer e outros.

Coligidas e Anotadas por Lygia Fernandes. Rio de Janeiro, ed. do autor, 1968.

. Música, Doce Música, São Paulo, Martins, s.d.

___ As Melodias do Boi e outras peças. São Paulo, Duas

Cidades/MinC/Instituto Nacional do Livro, 1987.

___ Música de feitiçaria no Brasil. Belo Horizonte/Itatiaia, Brasília/Instituto Nacional do Livro, 1983.

. Os cocos. São Paulo, Duas Cidades/Instituto Nacional do Livro, 1984.

. Danças dramáticas do Brasil. São Paulo, Martins, s.d.

___. . O Baile das Quatro Artes, São Paulo, Martins, s.d.

___. O Banquete, São Paulo, Duas Cidades, 1989.

___. O Empalhador de Passarinho, São Paulo, Martins, 1963.0

___ Obra Imatura, São Paulo/Belo Horizonte, Martins/Itatiaia, 1985.

___. Os Contos de Belazarte, São Paulo/Belo Horizonte, Martins/Itatiaia, 1980.

71 cartas de Mário de Andrade. Coligidas e anotadas por Lygia Fernandes. Rio de Janeiro, Livraria São José, s.d.

___. Táxi e Crônicas no Diário Nacional, São Paulo, Duas Cidades, 1976. 
Andrade, Oswald de. Serafim Ponte Grande, Rio de Janeiro, Civilização Brasileira, 1972.

___.Memórias sentimentais de João Miramar, São Paulo, Globo, 1990.

—_. Poesias reunidas, Rio de Janeiro, Civilização Brasileira. 1978. . Sentimento da Dialética na Experiência Intelectual Brasileira, São Paulo, Paz e Terra, 1992.

Arantes, Urias. "Macunaíma ou o mito da nacionalidade", Discurso, n.20, São Paulo, Departamento de Filosofia da USP, 1993.

Arinos, Afonso. Contos. São Paulo, Martins Fontes, 2006.

Athayde, Tristão de. Estudos - $3^{\mathrm{a}}$ série, Rio de Janeiro, Terra e Sol, 1928.

Auerbach, Erich. Mimesis, São Paulo, Perspectiva, s/d.

Avancini, Carlos Augusto. Expressão Plástica e Consciência Nacional na Crítica de Mário de Andrade. Porto Alegre, Editora da Universidade do Rio Grande do Sul, 1998.

Bakhtin, Mikhail. A Cultura Popular na Idade Média e no Renascimento O contexto de François Rabelais (trad. Yara Frateschi Vieira), São Paulo, Hucitec/Editora da Universidade de Brasília.

Bastide, Roger. "Macunaíma visto por um francês", Revista do Arquivo Municipal, n.106, São Paulo, 1946. Sociologia do folclore brasileiro. São Paulo, Anhembi, 1959.

Benjamin, Walter. Obras escolhidas I (trad. Sérgio Paulo Rouanet), São Paulo, Brasiliense, 1994.

__. "Goethes Wahlverwandtschaften", in Goethe, Die Wahlverwandtschaften. Frankfurt, Insel, 1982. 
Berriel, Carlos Eduardo. Dimensões de Macunaíma. Tese de doutoramento, Campinas, Unicamp, orientação de Roberto Schwarz. Mimeo.

. "A uiara enganosa", in Mário de Andrade/hoje, org. Berriel, Carlos Eduardo. São Paulo, Ensaio, 1990.

Bopp, Raul. Poesia completa (organização e comentários Augusto Massi). Rio de Janeiro/São Paulo, José Olympio/Edusp, 1998.

Bosi, Alfredo. "Moderno e modernista na literatura brasileira", in Céu e Inferno, São Paulo, Ática, 1988.

"Situação de Macunaíma", in Macunaíma, o herói sem nenhum caráter (ed. crítica de Telê Porto Ancona Lopez), Coleção Arquivos, 1988.

Brito, Antônio Carlos (Cacaso), "Alegria da Casa", Discurso, nº11, Departamento de Filosofia da USO, São Paulo, 1980.

Bueno, André Paula. Bumba-boi maranhense em São Paulo. São Paulo, Nankin/Cupuaçu/Fapesp/Cachuera, 2001.

Camargo, Suzana. Macunaíma - Ruptura e tradição. São Paulo, Massao Ohno/João Farkas, 1977.

Campos, Haroldo de. Morfologia de Macunaíma. São Paulo, Perspectiva, 1973.

"Miramar na mira", Oswald de Andrade, Memórias sentimentais de João Miramar, São Paulo, Globo, 1990.

__. "Uma poética da radicalidade". In: Andrade, Oswald. Poesias reunidas, Rio de Janeiro, Civilização Brasileira, 1978.

Candido, Antonio. O discurso e a cidade, São Paulo, Duas Cidades, 1993. . Vários escritos. São Paulo, Duas Cidades, 1970. 
Carone, Edgard. Movimento operário no Brasil (1877-1944). São Paulo, Difel, 1984.

__ O O tenentismo. Rio de Janeiro/São Paulo, Difusão Editorial/Difel, 1975.

Carvalho Franco, Maria Sílvia de. Homens Livres na Ordem Escravocrata, São Paulo, Kairós, 1983.

Castro, Moacir Werneck de. Mário de Andrade - Exílio no Rio, Rio de Janeiro, Rocco, 1989.

Costa, Emília Viotti da. Da monarquia à república: momentos decisivos. São Paulo, Livraria Editora Ciências Humanas Ltda., 1979.

Curtius, Ernst Robert. Französischer Geist im zwanzigsten Jahrhundert. Bern, Francke, 1952.

Dantas, Vinícius. "Entre 'A negra' e a Mata Virgem”. Novos Estudos CEBRAP, n.45. São Paulo, Cebrap, 1996. . "Oswald de Andrade e a poesia", Novos Estudos CEBRAP, n.30, São Paulo, julho de 1991.

Dean, Warren. A Industrialização de São Paulo (trad. Otávio Mendes Cajado), Rio de janeiro, Difel, s.d., $3^{\mathrm{a}}$ ed.

Duarte, Paulo. Mário de Andrade por ele mesmo, São Paulo, Hucitec/SMC, 1985.

Durkheim, Emile. Sociologia (org. José Albertino Rodrigues). São Paulo, Ática, 2000.

Facioli, Valentim. "Mário de Andrade e a cidade de São Paulo: aspectos", Revista da Biblioteca Mário de Andrade, São Paulo, jan/dez 1992, v.50. 
."Mário de Andrade: literatura e modernização", mimeo, 2001.

.O Brasil e o surrealismo: aspectos do campo da produção artística erudita no período de 1920 a 1950)", Organon, Instituto de Letras da Universidade do Rio Grande do Sul, Porto Alegre, 1994, n.28.

Farinaccio, Pascoal. Serafim Ponte Grande e as dificuldades da crítica literária. São Paulo, Ateliê, 2001.

Ferreira, Antonio Celso. A epopéia bandeirante: letrados, instituições, invenção histórica (1870-1940), São Paulo, Unesp, 2001.

Ferenczi, Sándor. Thalassa - ensaio sobre a teoria da genitalidade (trad. Álvaro Cabral). São Paulo, Martins Fontes, 1990.

Fonseca, Maria Augusta. "A carta pras Icamiabas", in Macunaíma, o herói sem nenhum caráter. Edição crítica coordenada por Telê Porto Ancona Lopez. São Paulo, Col. Arquivos, Unesco, 1988.

Frazer, James. Golden Bough: the scapegoat. New York, Macmillan, 1951.

Freyre, Gilberto. Casa-grande e senzala. Rio de Janeiro, São Paulo, Record, 1999.

Freud, Sigmund. A interpretação dos sonhos (trad. Walderedo Ismael de Oliveira). Rio de Janeiro, Imago, 2001.

Totem und Tabu, Gesammelte Werke 9. Frankfurt, Fischer, 1986.

Furtado, Celso. Formação econômica do Brasil. São Paulo, Companhia Editora Nacional, 1982.

Giumbelli, Emerson. "Lévy-Bruhl e a Antropologia", Novos Estudos CEBRAP no 42, julho de 1995. 
Hegel, G. W. F. Cursos de estética II (trad. Marco Aurélio Werle e Oliver Tolle), São Paulo, Edusp, 2000.

Holanda, Sérgio Buarque de, Raízes do Brasil. Rio de Janeiro, José Olympio, 1979.

"O mito de Macunaíma", O espírito e a letra, vol.I, org. Antonio Arnoni Prado. São Paulo, Companhia das Letras, 1996.

Lévy-Bruhl, Lucien. La mentalité primitive, Paris, Libraire Félix Alcan, 1922.

Lévi-Strauss, Claude. O pensamento selvagem (trad. Tania Pellegrini). Campinas, Papirus, 1997.

Lima Barreto, Afonso Henriques de. Policarpo Quaresma. São Paulo, Brasiliense, 1976.

Lobato, Monteiro. Cidades mortas. São Paulo, Brasiliense, 1956.

Lopes, Telê Porto Ancona. Mário de Andrade: Ramais e Caminho, São Paulo, Duas Cidades, 1972.

"Rapsódia e resistência", Macunaíma, o herói sem nenhum caráter.

Edição crítica coordenada por Telê Porto Ancona Lopez. São Paulo, Col. Arquivos, Unesco, 1988.

Lopes Neto, J. Simões. Contos gauchescos/ Lendas do Sul. São Paulo, Globo, 2001.

Lukács, Georg. A Teoria do Romance. In: Macedo, José M. M.. A teoria do romance: doutrina das formas e poética dos gêneros no jovem Lukács. Dissertação e tradução de mestrado. FFLCH-USP, São Paulo, 1997.

História e consciência de classe (trad. Telma Costa). Rio de 
Janeiro/ Elfos; Porto/Publicações Escorpião, 1989.

Ensaios sobre Literatura (trad. Leandro Konder et al.), Rio de Janeiro, Civilização Brasileira, 1968. . L'âme et les formes, Paris, Gallimard, 1974. . Ästhetik, Berlin, Luchterhand, 1963.

Magalhães, Couto de. O selvagem. São Paulo, Companhia Editora Nacional, 1935.

Marx, Karl. Manuscritos econômico-filosóficos e outros textos escolhidos (Trad. de José Carlos Brunni, José Arthur Giannotti e Edgard Malagodi). São Paulo, Nova Cultural, 1987.

O capital I (trad. Regis Barbosa e Flávio Kothe). São Paulo, Abril Cultural, 1985.

Medeiros, Sérgio (org.). Makunaíma e Jurupari - cosmogonias ameríndias. São Paulo, Perspectiva, 2002.

Mello, João Manuel Cardoso de. O capitalismo tardio. São Paulo, Brasiliense, 1991.

; Novais, Fernando A. "Capitalismo tardio e sociabilidade moderna". História da vida privada no Brasil 4 (org. Lilia M. Schwarcz). São Paulo, Companhia das Letras, 1998.

Moraes, Eduardo Jardim de. "Mário de Andrade: Retrato do Brasil", Mário de Andrade/hoje, org. Berriel, Carlos Eduardo. São Paulo, Ensaio, 1990.

Moretti, Franco. "O século sério - o romance europeu do Oitocentos", Novos Estudos CEBRAP n ${ }^{\mathrm{a}}$ 65, março de 2003.

Novais, Fernando; Mello, João Manuel Cardoso de. "Capitalismo tardio e 
sociabilidade moderna". História da vida privada no Brasil 4 (org. Lilia M. Schwarcz). São Paulo, Companhia das Letras, 1998.

Oliveira, Francisco de. Crítica à razão dualista/ o ornitorrinco. São Paulo, Boitempo, 2003.

"A emergência do modo de produção das mercadorias: uma interpretação teórica da economia da República Velha no Brasil”, in História Geral da Civilização Brasileira. O Brasil Republicano 1, São Paulo, DIFEL, 1975.

Pacheco, João. Poesia e Prosa de Mário de Andrade, São Paulo, Martins, 1970.

Pasta Jr., José Antonio. "Tristes estrelas da Ursa: Macunaíma”, Cadernos Porto \& vírgula, n.4, Porto Alegre, Secretaria Municipal da Cultura, 1993.

Prado, Paulo. Retratos do Brasil (org. Carlos Augusto Calil). São Paulo, Companhia das Letras, 1998.

Proença, Cavalcanti. Roteiro de Macunaíma. São Paulo, Civilização Brasileira, 1977.

Queiroz, Renato da Silva. Um mito bem brasileiro - estudo antropológico do saci. São Paulo, Polis, 1987.

Revista de Língua Portuguesa, Rio de Janeiro, nº 1, setembro de 1919. . n 46, março de 1927. no 49, setembro de 1927. $\mathrm{n}^{\circ} 54$, julho de 1928 .

Romero, Sílvio. Contos populares do Brasil. Belo Horizonte, Itatiaia, 1985.

Rosenfeld, Anatol. Negro, macumba e futebol Edunicamp/Edusp/Perspectiva, 1993. 
__. Texto/Contexto I, São Paulo, Perspectiva, 1996.

Saussure, Ferdinand de. Curso de lingüística geral (trad. José Paulo Paes et allii). São Paulo, Cultrix, s/d.

Santiago, Silviano, "A trajetória de um livro", Macunaíma, o herói sem nenhum caráter. Edição crítica coordenada por Telê Porto Ancona Lopez. São Paulo, Col. Arquivos, Unesco, 1988.

Schelling, F. W. J. Filosofia da arte (trad. Márcio Suzuki), mimeo.

Schiller, Friedrich. Poesia Ingênua e Sentimental (trad. Márcio Suzuki), São Paulo, Iluminuras, 1991.

Schlaffer, Heinz. Faust Zweiter Teil - die Allegorie des 19. Jahrhunderts. Stuttgart, J. B. Metzlersche, 1981.

Schwarz, Roberto. Ao Vencedor as Batatas, São Paulo, Duas cidades, 1992.

___ Duas Meninas, São Paulo, Companhia das Letras, 1997.

____ Que Horas São? Ensaios, São Paulo, Companhia das Letras, 1997.

___. Um Mestre na Periferia do Capitalismo/Machado de Assis, São Paulo, Duas Cidades, 1990.

Sodré, Moniz. O terreiro e a cidade. A forma social negro-brasileira, Rio de Janeiro, Imago/Fundação Cultural do Governo da Bahia, 2002.

Souza, Eneida Maria de. "A pedra mágica do discurso", in Macunaíma, o herói sem nenhum caráter. Edição crítica coordenada por Telê Porto Ancona Lopez. São Paulo, Col. Arquivos, Unesco, 1988.

Souza, Gilda de Mello e. Exercícios de Leitura, São Paulo, Duas Cidades, 1980.

O Tupi e o Alaúde: uma interpretação do Macunaíma, São Paulo, 
Duas Cidades, 1979.

.O Avô Presidente", revista Discurso, nº11, São Paulo, 1980.

Staiger, Emil. Grundbegriffe der Poetik. Zürich/Freiburg, Atlantis, 1946.

Spitzer, Leo. Linguistica e historia literaria. Madrid, Editorial Gredos, 1955.

Szondi, Peter. Teoria do Drama Moderno (trad. Luiz Repa), São Paulo, Cosac \& Naify, 2001.

Tassinari, Alberto. O espaço moderno. São Paulo, Cosac\&Naify, 2002.

Weber, Max. Os fundamentos racionais e sociológicos da música (trad. Leopoldo Waizbort). São Paulo, Edusp, 1995.

Wisnik, José Miguel. "A rotação das utopias-rapsódia", in Mário de Andrade/hoje, org. Carlos Eduardo Berriel. São Paulo, Ensaio, 1990.

____. "Unidos de mentira", in Ficção em debate e outros temas. Col. Remate de Males, São Paulo, Duas Cidades, 1979. 
